DOI: 10.20472/IAC.2020.054.003

\author{
NABA KUMAR ADAK \\ Sabang Sajanikanta Mahavidyalaya, West Bengal, India
}

\title{
AUSTRIAN SCHOOL OF ECONOMICS' SUGGESTION FOR INTRODUCING FREE PRIVATE BANKING SYSTEM IS SO ABSURD THAT IT CAN NEVER BE IMPLEMENTED
}

\begin{abstract}
:
Economists of Austrian School think that a few commodities (ultimately gold and silver) emerged as mediums of exchange out of the barter system. They think if money were commodity-money, only then exchanges will be done smoothly without causing any adverse effect on the economy. The supply of any amount of fiat-money proves to be over-supply of money, as no extra commodity is created corresponding to the creation of the fiat-money. Increase in fiat money reduces the value of the money and the price of commodities rises. They think, that to be able to spend more than its tax-receipts can support, the government will allow the central bank to fraudulently increase fiat-money. Austrian economists also think that the central bank (CB) allows the commercial banks to create credit-money. They think the government and the central bank jointly inflate (increase) the supply of fiat-money. This causes inflationary pressure on the economy and leads the economy to cycles of recessions. So, they prescribe that the government and the CB should be deprived of their monopoly power to create money and that only private banks should be allowed to create money. They think that private bankers will not increase supply of money to that extent that can harm the stability of money and the Consumer Price Index. The Austrian economists suggest how the private bankers will create money and how the people will accept or reject any money to hold. They argue that private banks will manage their own affairs if they were left without any external interference.

The purpose of this paper is to show that the alternative processes suggested by the Austrian School of Economists are very much impractical and detrimental to the economy. In their private banking system, different banks will issue notes of different denominations. People will have to be always on alert to see which money becomes more stable than other moneys. Private Banks will also have to remain always on guard lest their money is devalued in competition to other banks' moneys. There is no guarantee that no private bank will fall. Thus, both private banks and the people will be puzzled in deciding what policy or action will be the best choice for keeping the value of their money stable or which money they should hold so that they do not face any future devaluation or any bank-failure. Therefore, the private banking system will lead to uncertainty and complete chaos in the monetary and financial systems.
\end{abstract}

\section{Keywords:}

Fractional reserve free banking, $\mathrm{Ma}, \mathrm{Mb}$, Commodity credit, Circulation credit, Fiduciary media, Abolition of Central Bank, Mal-investment, unemployment, concurrent currencies, boom-bust cycle, bunch of commodity reserve standard, 'a collection of raw material prices' standard, sound money, stable money, private banking

JEL Classification: B53, E52, E62 


\section{Introduction:}

Economists could not yet define money properly. There are difference among different schools of economics regarding the nature and function of money. Among different schools, Austrian School of Economics has recently gathered many supporters and followers. Their definition of money differs in many ways from other school of economics. While Modern Money Theory argues that money must be debt-money and must be created out of nothing by the government. The Austrian School argues exactly opposite; they argue that money must be commodity-money and must be created not by the government but by the private bankers. Modern Money Theorists draw their logic from the writings of their ancestors like Innes, Ingham and Lerner who lived in early $20^{\text {th }}$ century. Austrian economists draw their logic from the writings of Menger who also lived in the early $20^{\text {th }}$ century. As Menger and most of his early followers were Austrians, so the name of this school of economic thought has become known as Austrian School of Economics. However, many of the present generation Austrian School of Economists live in the USA and the Headquarter of this school is situated in Auburn in the USA.

Douglas E. French wrote, "Menger's work provided the foundation for all of the Austrian School and the bedrock for monetary theory, laying the groundwork for Mises, Hayek, and Rothbard." [Menger (1892) 2009, p. 9] The eminent economists of Austrian school were/ are Ludwig von Mises, Henry Hazlitt, Friedrich Hayek, Hans-Hermann Hoppe, Jesus Huerta de Soto, Jörg G Hülsmann, George Selgin, Murray N. Rothbard, Robert P. Murphy, Frank Shostak etc.

Economists of Austrian School argue that money must be commodity as some commodity had been accepted as medium of exchange to lubricate the barter system bypassing the problem of double coincidence of wants. To them money derives its value from the amount of its content of the commodity of which it is made. Therefore, to them any money that is not a commodity or not backed by any commodity is fraudulent money or fiat money. As no commodity is created against the fiat money, so no supply of commodity is increased corresponding to the increase of such fiat money. Therefore, increase in fiat money increases the supply of money in the market and thus causes rise in prices of commodities. Therefore, if money remains tied to commodities only then the supply of commodity-money should be considered that increase in money-supply commensurate the increase of commodities because commodity money itself is a commodity and money. Austrian economists argue that government has empowered the central bank to create money out of nothing to get unlimited supply of money from the central bank to be able to spend more than its tax-receipts can support. Government also reduces the interest rate on borrowing money from the central bank to reduce its burden of loan. Thus, government reduces the interest rate than whatever may be the natural interest rate of lending if money would remain only commodity-money and the issuance of money is not controlled by the government. This low rate of interest on borrowing lures the enterprisers to borrow more to invest more in businesses and thus economic activities becomes faster and boom phase is quickened. Demand for commodities does not increase in the same pace as the production of commodities increases. Thus, boom becomes bust and recession sets in and employment shrinks causing increase in unemployment. The Austrian economists hold the government and the central bank responsible for business-cycle, recession and unemployment as they (the government and the central bank) jointly create \& increase the supply of fiat money and reduce interest rate. They think that as both of these two institutions (the government and the central bank) monopolized the money-creation, so people cannot escape the harmful effects of the monetary policy (creating fiat money and reducing interest rate). They argue that people should be allowed to create money of their own and to decide the natural rate of interest rate. They also argue that like all other commodities that can be freely traded, money (because it is also a commodity) should be created and freely traded; the monopoly on money creation and fixing interest rate on lending should also be abolished. They argue, therefore, both these organizations (the government and the central bank) should 
be deprived of their monopoly power of creating money and fixing rate of interest low (which they will and must do if they have the monopoly) and people (anybody) should have the right to create money and lend the money according to his own rate of interest. As many people will issue moneys of different commodities and in different denominations and values, so people must have the right to chose any money (among various types of money) which they think more stable than other moneys and like to hold. Austrian economists have also suggested in which manner monopoly on money (of the government and the central bank) should be abolished and how the private bankers (who will create money in the free market) will manage their monetary policies and how the people will use those moneys.

In the literature survey, I will narrate how the Austrian economists explain their idea of commoditymoney what they call in different names like 'sound money,' 'stable money', 'good money' etc. I will explain their logic why the government and the central bank should be deprived of their monopoly power of issuing money and fixing interest rate. I will also explain their prescriptions of process how this monopoly power can be abolished and how the private bank and the people will react to the free banking system. Then, I will assess /estimate of their theory of private banking. We will see that the Austrian economists have failed to give us the alternative money and banking system that is more sound/ stable or practical than the government money. I will explain that Austrian economists have even no vague idea about what shape the money and the financial system will take in future after the abolition of the monopoly power of money-making of the government and the central bank. Next, I will explain why the Austrian economists have failed to grasp how money, banking, monetary, and fiscal policy work in the economy. Then I will explain the systemic defect in the economic system (that I think) that is the root cause of continuous and chronic deterioration of the economy. Then there will be my suggestion and the conclusion. At the end, I will submit my limitation in my paper.

\section{Literature Survey}

\section{1. Austrian School's Definition of money}

At first economists of Austrian school defined money as $100 \%$ commodity-money what they call 'sound money'. Then they shifted from their argument for 'commodity money standard' to the argument for 'commodity reserve standard' that is a host of commodities including gold and silver will be reserved against the money that the private banks will issue. Again, as 'commodity reserve standard' will create storage problem of all the commodities in the banks reserve, they shifted from their argument for 'commodity reserve standard' to the argument for 'a collection of raw material prices' as the standard for money. Thus, the Austrians economists vacillate in fixing the standard for money. Thus, in their argument, at last, money loses its 'commodity standard'. They fail to define money and the standard for money. Money's standard, thus, became dependent on the changes (increase and or decrease) in the Commodity Price Index.

\subsection{A. Sound Money (Commodity Money)}

Menger writes that, "Even at this day we have no satisfactory theory of money." [Menger 1892, p. 15] Therefore, as a rational definition of money they claim that money must be commodity what they call 'sound money'.

The Austrian economists argue that some commodity had emerged spontaneously as medium of exchanges to lubricate the exchange between commodities to avoid the problem of double coincidence in the barter system. According to the Menger's explanation of the origin of money, money emerged as "the 
spontaneous outcome, the unpremeditated resultant, of particular, individual efforts of the members of a society, who have little by little worked their way to a discrimination of the different degrees of saleableness in commodities." [Menger 1892, p. 38] As gold and silver were more salable, so gradually gold and silver became more widely used as money than other commodities.

The essence of Austrian economics is that money should and must be made of $100 \%$ metal (preferably gold and silver) as opposed to any money that is debased or depreciated or created as fiduciary/ fiat money against no reserve. "Hazlitt favored a "pure" gold standard, or a 100 percent reserve requirement. ... Any expansion of credit above the amount of gold held in reserve was fraudulent, and as such, should be prosecuted by government authorities, he wrote in The Inflation Crisis, and How to Resolve It." [Blanchette, 2004, p 35].

The Austrian economists argue that money can be divided in two categories according to their soundness. Ebeling differentiates between 'sound money' and 'unsound money' thus: “"'sound money" was considered to be one based on a commodity standard, most frequently either gold or silver. In contrast, the history of paper, or fiat, monies was seen as an account of abuse, mismanagement and financial disaster, and thus "unsound" money." [Ebeling 2012 Aug, p. 1]

"Sound money meant a metallic standard. Standard coins should be in fact a definite quantity of the standard metal as precisely determined by the law of the country. Only standard coins should have unlimited legal-tender quality. Token coins and all kinds of money like paper should be, on presentation and without delay, redeemed in lawful standard money." [Mises 1953, p. 415] Money should contain $100 \%$ metal of which it is made and not an alloy that can debase the value of money. Murray Rothbard explained it thus: "The world was on a gold standard, which meant that each national currency (the dollar, pound, franc, etc.) was merely a name for a certain definite weight of gold. The "dollar," for example, was defined as 1/20 of a gold ounce, the pound sterling as slightly less than $1 / 4$ of a gold ounce.... This meant that the "exchange rates" between various national currencies were fixed, not because they were arbitrarily controlled by government, but in the same way that one pound of weight is defined as being equal to sixteen ounces." [Murray N. Rothbard, What Has Government Done to Our Money? [Auburn, AL: Ludwig von Mises Institute, 1990 p. 23-24.] [Quoted in Ebeling 2012, p. 2] They argue, "The mutual gains from trade could be expanded by extending the principle of division of labor to a global scale. If men were to benefit from those possibilities, a stable, sound, and trustworthy monetary order had to assist in the internationalization of trade. Gold was considered the commodity most proven through the ages to serve that function. And preservation of the gold standard, therefore, was given a prominent place among the limited duties assigned to the classical-liberal state in that earlier era." [Ebeling 2012 Aug, p. 3]

In the past Kings (government) used to reduce the metal content of coins to make more coins out of same amount of the metal and passed them off as full-bodied coins. Hayek writes, "from retaining an excessive part of the metal brought to the government mint to be struck into new coins, it was only a step to the practice, increasingly common during the Middle Ages, of recalling the circulating coins in order to recoin the various denominations with a lower gold or silver content. We shall consider the effect of these debasements." [Hayek 1976, p. 30] "The classical liberals were deeply suspicious of government abuse of the printing press. They believed that only a monetary system under which all bank-issued notes and other deposit claims were redeemable on demand for gold could act as a sufficient check against the abuse and debasement of a currency." [Ebeling 2012, p. 4] 
To prevent such debasement of coins or as a remedy of such debasement, people and the economists demanded that money should not be debased and that money must contain the same amount of commodity the value of which is equal to its face-value. This may be termed as a movement for "sound money". "It is impossible to grasp the meaning of the idea of sound money if one does not realize that it was devised as an instrument for the protection of civil liberties against despotic inroads on the part of governments." [Mises 1953, p. 414] “... from Roman times to the 17 th century, when paper money in various forms begins to be significant, the history of coinage is an almost uninterrupted story of debasements or the continuous reduction of the metallic content of the coins and a corresponding increase in all commodity prices." [Hayek 1976, p. 33] "The postulate of sound money was first brought up as a response to the princely practice of debasing the coinage." [Mises 1953, p. 414]

"Thus the sound-money principle has two aspects. It is affirmative in approving the market's choice of a commonly used medium of exchange. It is negative in obstructing the government's propensity to meddle with the currency system." [Mises 1953, p. 414]

"Debasement and depreciation of media of exchange through monetary manipulation has been the hallmark of recorded history. To prevent such abuses and their deleterious effects, advocates of freedom supported the gold standard to impose an external check on monetary expansion. Paper money was to be "convertible," redeemable on demand to banknote and checking account holders at a fixed ratio of redemption. [Ebeling 2012, p. 11] Thus, the Austrian economists use "sound money" to mean gold standard. "The excellence of the gold standard is to be seen in the fact that it renders the determination of the monetary unit's purchasing power independent of the policies of governments and political parties." [Mises 1953, p. 416] "The importance of a monetary system based on gold, therefore, is that it limits the range of discretion open to governments to manipulate the quantity and value of money. The fundamental rule that the supply of money in the economy is anchored to the profitability of gold production as determined by market forces depoliticizes the monetary system to a significant degree." [Ebeling 2012, p. 2]

"The supply of gold is governed by nature; it is not, like the supply of paper money, subject merely to the schemes of demagogues or the whims of politicians. Nobody ever thinks he has quite enough money. Once the idea is accepted that money is something whose supply is determined simply by the printing press, it becomes impossible for the politicians in power to resist the constant demands for further inflation."[Hazlitt 1969, p.162] Austrian economists discard such creation of money by the government. They argue, "... no money, and no money-unit, can ever emerge except through this process of beginning as a useful nonmonetary commodity in barter. Money must begin as a useful commodity in a market economy of barter. Otherwise, it could not have had a preexisting purchasing power so that people can evaluate and hold money. Unfortunately, once a commodity is established as money, paper or bank deposits can begin as representations of and redeemable in, genuine commodity money". [Rothbard Undated, p. 181]

"Under the gold standard, the quantity of money and hence its value is determined solely by market forces, such as the demands of the public for money and the costs associated with digging up gold. While the purchasing power of a pure commodity money such as gold, like the price of any commodity on the free market, therefore tends to fluctuate according to changes in its supply and demand, there exists an inherent long-run tendency to stability in the value of such a money. This contrasts sharply with a government-monopolized fiat money which, as noted above, is inherently inflationary and subject to large, unpredictable fluctuations in value over both the short- and long-terms." [Salerno 1982, p. 2] 
In support of metallic standard of money, Mises argues that "Before an economic good begins to function as money it must already possess exchange-value based on some other cause than its monetary function." [Mises 1953, p. 111] "Given an established redemption ratio between bank notes and deposit accounts and a quantity of gold on deposit in banks; given fixed reserve requirements on checking and other forms of bank deposits; given an established rule of the right of free import and export of gold between one's own country and the rest of the world; and assuming that the political authority with responsibility over the country's monetary system does not interfere with these conditions and rules, then political influences on the value and quantity of money would be minimized. [Ebeling 2012, p. 2]

\subsection{B. Shift from Sound Money (Commodity Money) to 'Commodity Reserve Standard'}

However, Hayek himself has no faith in the pure gold standard, because he thinks it as an unsteady anchor. He writes, "Though gold is an anchor-and any anchor is better than a money left to the discretion of government - it is a very wobbly anchor. It certainly could not bear the strain if the majority of countries tried to run their own gold standard. There just is not enough gold about. An international gold standard could today mean only that a few countries maintained a real gold standard while the others hung on to them through a gold exchange standard." [Hayek 1976, p. 110].

Commodity money has its other inconveniences. As the production of commodity money cannot keep pace with the increase of other marketable commodities so the value of commodity money will keep on increasing. A time will come when commodity money (gold money) could not be divided further to facilitate exchanges in retail market. Ebeling writes, "But commodity money, as history has shown, has its inconveniences in everyday transactions in the market." [Ebeling 2012, p. 9]

Therefore, commodity standard should and must be replaced with other types of money-systems in which quantity of money can be increased to meet the increased demand for money. Hayek writes, "In the course of such a revolution of our monetary system, the values of the precious metals, including the value of gold, are going to fluctuate a great deal, mostly upwards, and therefore those of you who are interested in it from an investor's point of view need not fear. But those of you who are mainly interested in a good monetary system must hope that in the not too distant future we shall find generally applied another system of control over the monetary circulation, other than the redeemability in gold." [Hayek April 2019, p. 5]

Due to "its [gold standard] incompatibility with a policy of credit expansion" [Mises 1953, p. 421], Mises suggested that a combination of many commodities may be reserved as the standard of money creation. "It may be that, with free competition between different kinds of money, gold coins might at first prove to be the most popular. But this very fact, the increasing demand for gold, would probably lead to such a rise (and perhaps also violent fluctuations) of the price of gold that, though it might still be widely used for hoarding, it would soon cease to be convenient as the unit for business transactions and accounting. There should certainly be the same freedom for its use, but I should not expect this to lead to its victory over other forms of privately issued money, the demand for which rested on its quantity being successfully regulated so as to keep its purchasing power constant. [Hayek 1976, pp. 130-131] Therefore, Hayek suggests 'a commodity reserve standard' (a combination of large variety of raw materials) as an alternative to the 'complicated and expensive' gold standard. He writes, "There would in that event also be no need to encumber the money supply with the complicated and expensive provision for convertibility which was necessary to secure the automatic operation of the gold standard and which made it appear as at least more practicable than what would ideally seem much more suitable - a commodity reserve standard. A very attractive scheme for storing a large variety of raw materials and other standard commodities had been worked out for such a standard to ensure the redeemability of the currency unit by a fixed combination of such commodities and thereby the stability of the currency." [Hayek 1976, p. 110] 
"It would therefore now be possible, if it were permitted, to have a variety of essentially different monies. They could represent not merely different quantities of the same metal, but also different abstract units fluctuating in their value relatively to one another. In the same way, we could have currencies circulating concurrently throughout many countries and offering the people a choice.” [Hayek 1976, p. 32]

\subsection{Shift from 'Commodity Reserve Standard' (collection of many different materials) to 'token money' and 'Value of Money' or 'a collection of raw material prices' as the standard for money creation}

However, again Hayek does not think that 'commodity reserve standard' can really be practicable because of the expensive storage problem. Therefore, Hayek is ready to allow bankers to keep reserves less than the $100 \%$ so long as the bankers manage the money policy prudently. He thinks that $100 \%$ "convertibility is a safeguard necessary to impose upon a monopolist, but unnecessary with competing suppliers". He writes, "Storage would however be so expensive, and practicable only for such a small collection of commodities, as to reduce the value of the proposal. But some such precaution to force the issuer to regulate the amount of his currency appears necessary or desirable only so long as his interest would be to increase or decrease its value above or below the standard, Convertibility is a safeguard necessary to impose upon a monopolist, but unnecessary with competing suppliers who cannot maintain themselves in the business unless they provide money at least as advantageous to the user as anybody else." [Hayek 1976, pp. 110-111]

Hayek thinks that gold standard is not necessary to secure 'good (sound) money'. He writes, "I have said that it is an erroneous belief that the value of gold or any metallic basis determines directly the value of the money. The gold standard is a mechanism which was intended and for a long time did successfully force governments to control the quantity of the money in an appropriate manner so as to keep its value equal with that of gold." [Hayek April 2019, p.2] "gold is not really necessary to secure a good currency." [Hayek April 2019, p.3]

Hayek thinks that 'token money' (not backed by any commodity) may be good (sound) money if its quantity is so regulated that the purchasing power of the token money can remain constant. He writes, "But there are many historical instances which prove that it is certainly possible, if it is in the self-interest of the issuer, to control the quantity even of a token money in such a manner as to keep its value constant." [Hayek April 2019, p.2]

"I think it is entirely possible for private enterprise to issue a token money which the public will learn to expect to preserve its value, provided both the issuer and the public understand that the demand for this money will depend on the issuer being forced to keep its value constant; because if he did not do so, the people would at once cease to use his money and shift to some other kind." [Hayek April 2019, p.3] Hayek writes, "it [is] very doubtful whether gold was for the purpose of money really a good standard. It would turn out to be a very good investment, for the reason that because of the increased demand for gold the value of gold would go up; but that very fact would make it very unsuitable as money. You do not want to incur debts in terms of a unit which constantly goes up in value as it would in this case, so people would begin to look for another kind of money: if they were free to choose the money, in terms of which they kept their books, made their calculations, incurred debts or lent money, they would prefer a standard which remains stable in purchasing power." [Hayek 1979, p. 4]

Hayek remains no more strict (as he earlier was) in advocating that money must be backed by $100 \%$ reserve and that money must be $100 \%$ convertible in metallic standard like gold and silver. Even if money becomes inconvertible, Hayek now begins to think that people will voluntarily accept the money issued by those bankers who do not keep $100 \%$ reserve but manage the money policy prudently to keep the value 
of money stable. He writes, "any money which is voluntarily used only because it is trusted to be kept scarce by the issuer, and which will be held by people only so long as the issuer justifies that trust, will increasingly confirm its acceptability at the established value. ... This is a state of affairs that can continue indefinitely and will even tend to stabilise itself more and more as confirmed expectations increase the trust." [Hayek 1976, p. 112] Thus, "a mere token money which did not give the holder a legal claim for redemption in terms of some object possessing an intrinsic value (equal to its current value) could ever be generally accepted for any length of time or preserve its value." [Hayek 1976, p. 112]

Hayek thinks that even if money is not backed by any commodity standard, yet the competition among the private bankers to make profit from money-making would induce the private banks to regulate their money making policy in such a prudent manner that the value of money will remain constant and there will be no problem of accepting that money by the people. He writes, "Competition would certainly prove a more effective constraint, forcing the issuing institutions to keep the value of their currency constant (in terms of a stated collection of commodities), than would any obligation to redeem the currency in those commodities (or in gold). And it would be an infinitely cheaper method than the accumulation and the storing of valuable materials." [Hayek 1976, p. 48]

"On the whole I would expect that, for reasons to be explained later, a collection of raw material prices, such as has been suggested as the basis of a commodity reserve standard, 1 would seem most appropriate, both from the point of view of the issuing bank and from that of the effects of the stability of the economic process as a whole. [Hayek 1976, p. 48] Hayek is confident that "It would seem that in this situation sheer desire for gain would produce a better money than government has ever produced." [Hayek 1976, p. 51]

However, "The very same fact which at present makes gold more trusted than government-controlled paper money, namely that its total quantity cannot be manipulated at will in the service of political aims, would in the long run make it appear inferior to token money used by competing institutions whose business rested on successfully so regulating the quantity of their issues as to keep the value of the units approximately constant." [Hayek 1976, p. 131]

\section{Assessment of the Austrian School's Definition of money}

Austrian School's demand that if it is gold standard then money supply would not increase is wrong. Hayek himself writes that excessive gold production may lead to inflationary effects on the economy causing devaluation of money or increase in commodity-prices. He gives a example, "When in the 'fifties of the nineteenth century gold production increased considerably in California and Australia, people attacked the gold standard as inflationary. In those days Michel Chevalier, in his book Probable Depreciation of Gold, recommended the abandonment of the gold standard, and Béranger dealt with the same subject in one of his poems." [Mises 1953, p. 416]

Hayek wrote, "it [is] very doubtful whether gold was for the purpose of money really a good standard. It would turn out to be a very good investment, for the reason that because of the increased demand for gold the value of gold would go up; but that very fact would make it very unsuitable as money. You do not want to incur debts in terms of a unit which constantly goes up in value as it would in this case." [Hayek 1979, p. 4]

Hayek's intention was not to have a gold standard or commodity standard or fixed rate of exchange but to restrict the tendency of increase in money supply. Hayek thinks of some disciplinary measures to check changes in the quantity of money to achieve a healthy economy. He suggests, "The gold standard, fixed rates of exchange, or any other form of obligatory conversion at a fixed rate, served no other purpose than 
to impose upon the issuers of money such a discipline and, by making its regulation automatic, to deprive them of the power arbitrarily to change the quantity of money." [Hayek 1976, p. 109] "I have always defended the gold standard, and later fixed exchange rates, not because I thought they resulted in particularly good money but because they provided the only effective protection from government abuse of its monopoly to issue money." [Hayek Oct. 2014]

From the above discussion, we find that the Austrian economists blamed the government and the central bank for issuing fiat money (not backed by any commodity), but ultimate they allow the private bankers in the free market (after the abolition of monopoly authority of money-making of the government and the central bank) to issue fiat money. It seems that the Austrian economists have no consistency in their approach to define what money is.

\subsection{The Government and the Central Bank should be deprived of their monopoly in money- creation as they cannot give us good money; and people should be allowed to create money unhampered by any control of any national or international financial or monetary super-structure}

\subsection{A. According to the Austrian economists Government cannot avoid or abandon creating fiat (fiduciary) money}

Austrian economists argue that as government cannot raise tax and borrow from the public unlimited, so the government rejected the gold standard and began to issue unlimited fiat money. They wrote, "tax increases have always found little favor among the citizenry. So, ever fearful of arousing popular unrest, governments naturally sought alternative means for augmenting their revenues from taxation. It was for this purpose that all national governments eventually secured for themselves a legal monopoly of issuing money, empowering them to inflate, i.e., to create new money, virtually at will." [Salerno 1982, p. 1] Mises writes, "the gold standard did not collapse. Governments abolished it in order to pave the way for inflation" [Mises 1953, p. 420] and "Recourse to inflation may provide the government with the funds which it could neither collect by taxation nor borrow from the savings of the public because the people and its parliamentary representatives objected." [Mises 1953, p. 428]

Austrian economists think that inflation (increase of supply of fiat-money not tied to gold) cannot be the alternative to 'sound money' (commodity money). Mises writes, "inflationism is not a monetary policy that can be considered as an alternative to a sound-money policy" [Mises 1953, p. 419] and "resort to inflation cannot be considered seriously as an alternative to a permanent standard such as the gold standard is." [Mises 1953, p. 420]

According to the Austrian School, increases in fiat-money supply, ultimately, leads to increase in unemployment and to recurrent waves of depression. Hayek writes, "I am afraid, a whole generation of economists have been teaching, that government has the power in the short run by increasing the quantity of money rapidly to relieve all kinds of economic evils, especially to reduce unemployment. Unfortunately this is true so far as the short run is concerned. The fact is, that such expansions of the quantity of money which seems to have a short run beneficial effect, become in the long run the cause of a much greater unemployment. But what politician can possibly care about long run effects if in the short run he buys support?" [Hayek, 2019 April, p.1] and "The abolition of the government monopoly of money was conceived to prevent the bouts of acute inflation and deflation which have plagued the world for the past 60 years. It proves on examination to be also the much needed cure for a more deep-seated 
disease: the recurrent waves of depression and unemployment that have been represented as an inherent and deadly defect of capitalism." [Hayek, 1976, p. 130]

\subsection{B. As Government will never abandon its policy of creating fiat money, so its monopoly power over money creation should be abolished and private banks should also be allowed to issue money}

It would not be possible to make government to re-introduce gold standard (sound money), because, government will not remain bound by the law of $100 \%$ gold standard. Mises argues that in the present system of money-creation, "If an administration and the party backing it wants to increase expenditure without jeopardizing their popularity through the imposition of higher taxes, they will always be ready to call their impasse an emergency. Recourse to the printing press and to the obsequiousness of bank managers, willing to oblige the authorities regulating their conduct of affairs, is the foremost means of governments eager to spend money for purposes for which the taxpayers are not ready to pay higher taxes." [Mises 1998, p. 440] Government cannot stop creating fiat-money. Hayek writes, "“II am afraid I am convinced that the hope of ever again placing on government this discipline is gone." [Hayek 2019 April, p.1] Salerno writes "To put it rather bluntly, government is an inherently inflationary institution and will ever remain so until it is dispossessed of its monopoly of the supply of money." [Salerno 1982, p. 1] Hayek thought, "What is so dangerous and ought to be done away with is not governments' right to issue money but the exclusive right to do so and their power to force people to use it and to accept it at a particular price. ... All history contradicts the belief that governments have given us a safer money than we would have had without their claiming an exclusive right to issue it." [Hayek (1976) 2009, p. 16] Hayek argues that "I have no objection to governments issuing money, but I believe their claim to a monopoly, or their power to limit the kinds of money in which contracts may be concluded within their territory, or to determine the rates at which monies can be exchanged, to be wholly harmful." [Hayek (1976) 2009, p. 17] "If we want free enterprise and a market economy to survive (as even the supporters of a so-called 'mixed economy' presumably also wish), we have no choice but to replace the governmental currency monopoly and national currency systems by free competition between private banks of issue." [Hayek (1976), 1990, p. 130].

Hayek argues that, "nothing can be more urgent than that we dissolve the unholy marriage between monetary and fiscal policy" [Hayek (1976) 1990, p. 117], because as a result of both fiscal policy and monetary policy remaining in the same hand of the government, "Even during relatively stable periods the regular necessity for central banks to accommodate the financial 'needs' of government by keeping interest rates low has been a constant embarrassment: it has interfered with the banks' efforts to secure stability and has given their policies an inflationist bias." [Hayek (1976) 1990, p. 117] and "Good national money [is] impossible under democratic government dependent on special interests." [Hayek (1976) 1990, p. 117]

Hayek argues that as government is prone to finance its deficit expenditure through creating additional money and that increased money supply is the major cause of monetary and price instability, so government should be deprived of its power over money. He writes, "the power over money has also relieved governments of the necessity to keep their expenditure within their revenue" [Hayek (1976) 1990, p. 118] and "the argument that government deficits are necessary to reduce unemployment amounts to the contention that a government control of money is needed to cure what it is itself causing" [Hayek (1976) 1990, p. 119] Therefore, "While governments will of course occasionally be forced to borrow from the public to meet unforeseen requirements, or choose to finance some investments in that manner, it is highly undesirable in any circumstances that these funds should be provided by the creation of additional money." [Hayek (1976) 1990, p. 120] Therefore separation of monetary policy from the hands of the governments is an urgent necessity. Hayek writes. "The more completely public finance can be separated from the regulation of the monetary circulation, the better it will be. It is a power which always has been harmful. Its use for financial purposes is always an abuse. And government has neither the 
interest nor the capacity to exercise it in the manner required to secure the smooth flow of economic effort.” [Hayek (1976) 1990, p. 120]

Hayek argues, "There could be no more effective check against the abuse of money by the government than if people were free to refuse any money they distrusted and to prefer money in which they had confidence. Nor could there be a stronger inducement to governments to ensure the stability of their money than the knowledge that, so long as they kept the supply below the demand for it that demand would tend to grow. Therefore, let us deprive governments (or their monetary authorities [the Central Bank]) of all power to protect their money against competition: if they can no longer conceal that their money is becoming bad, they will have to restrict the issue." [Hayek (1976) 2009, p. 18]

\subsection{There should be no national or International authority to guide or monitor the affairs of the private banks}

"Hayek was highly critical of "monetary nationalism" namely the management of currency by a monopolistic central bank which imposes an inflation tax by overshooting monetary targets." [Ravier No date] Hayek writes "I prefer the freeing of all dealings in money to any sort of monetary union also because the latter would demand an international monetary authority which I believe is neither practicable nor even desirable - and hardly to be more trusted than a national authority." [Hayek (1976) 2009, p. 21]

They also argue that there should not be any monetary policy to regulate the process of money-creation by the private banks. Hayek prescribes that it would be rational if there remains no monetary policy at all. He writes, "You may feel that my proposal amounts to no less than the abolition of monetary policy; and you would not be quite wrong. As in other connections, I have come to the conclusion that the best the state can do with respect to money is to provide a framework of legal rules within which the people can develop the monetary institutions that best suit them. It seems to me that if we could prevent governments from meddling with money, we would do more good than any government has ever done in this regard. And private enterprise would probably have done better than the best they [governments] have ever done.” [Hayek (1976) 2009, p. 22]

Hayek argues that, "under such a system [free issue of competitive currencies] what is known today as monetary policy would neither be needed nor even possible." [Hayek (1976) 1990, p. 101]

As a first step for implementation of private freedom to create money and to accept or reject any money, the Austrian economists suggest that exchange control of money's movement among nation should be abolished and any bank should have the freedom of opening its branches any country. Hayek writes, "The concrete proposal for the near future, and the occasion for the examination of a much more far-reaching scheme ... would mean in the first instance the abolition of any kind of exchange control or regulation of the movement of money between these countries, as well as the full freedom to use any of the currencies for contracts and accounting. Further, it would mean the opportunity for any bank located in these countries to open branches in any other on the same terms as established banks." [Hayek (1976) 1990, p. 23] "The main advantage of the proposed scheme ... is that it would prevent governments from ... further employing these harmful tools. They would become unable to conceal the depreciation of the money they issue ... The scheme would indeed seem to satisfy all the requirements of a common market better than a common currency without the need to establish a new international agency or to confer new powers on a supra-national authority." [Hayek (1976) 1990, p. 25] 


\subsection{If private banks can create money in free market then the economy will be secured against crises and depression and civilization will be saved}

Mises argues that "Only free banking would have rendered the market economy secure against crises and depressions." [Mises 1998, p. 440] Hayek argues, "the only way to avoid being driven by continuing inflation into a controlled and directed economy, and therefore ultimately in order to save civilization, will be to deprive governments of their power over the supply of money." [Hayek (1976) 1990, p. 133] "Government has prevented enterprise from equipping itself with the instruments that it required to protect itself against its efforts being misdirected by an unreliable money and that it would be both profitable for the supplier and beneficial to all others to develop. The recognition of this truth makes it clear that the reform proposed is not a minor technicality of finance but a crucial issue which may decide the fate of free civilization. What is proposed here seems to me the only discernible way of completing the market order and freeing it from its main defect and the cause of the chief reproaches directed against it." [Hayek (1976) 1990, pp. 131-132] Hayek thinks that abolition of government control over money and allowing money to be created by private investors will be beneficial. He writes, "What is now urgently required is not the construction of a new system but the prompt removal of all the legal obstacles which have for two thousand years blocked the way for an evolution which is bound to throw up beneficial results which we cannot now foresee." [Hayek (1976) 1990, p. 134]

\subsection{E. Central Bank's policy of lowering Interest rate should be abolished}

Hayek argues that the 'interest policy' of the central bank should be abolished because central bank keeps the interest rate low "which are intended to enable it [government] to borrow cheaply a practice which has done so much harm in the past that this effect alone would seem an adequate reason why government should be kept away from the tap." [Hayek (1976) 1990, p. 107] Ravier gave an example that "between 1694 and the early nineteenth century the British Treasury benefited from low-interest loans offered by the Bank of England to finance the government's fiscal deficits." [Ravier No date]

Mises wrote "three tendencies toward a lowering of the gross market rate of interest were operating at the same time and strengthening one another. One was the outgrowth of the steady increase in the quantity of commodity money; the second the outgrowth of a spontaneous development of fiduciary media in banking operations; the third the fruit of intentional anti-interest policies sponsored by the authorities and approved by public opinion. It is, of course, impossible to ascertain in a quantitative way the effect of their joint operation and the contribution of each of them; an answer to such a question can only be provided by historical understanding." [Mises 2010 June 11, Mises Daily Articles]

Hayek writes, "The disappearance of what is called 'interest policy' is wholly desirable. The rate of interest, like any other price, ought to record the aggregate effects of thousands of circumstances affecting the demand for and supply of loans which cannot possibly be known to anyone agency. ... The whole idea that the rate of interest ought to be used as an instrument of policy is entirely mistaken, since only competition in a free market can take account of all the circumstances which ought to be taken account of in the determination of the rate of interest. So long as each separate issue bank in its lending activity aimed at regulating the volume of its outstanding currency so as to keep its buying power constant, the rate of interest at which it could do so would be determined for it by the market." [Hayek (1976) 1990, p. 107]

However, tendency of lowering interest rate (as is argued by the Austrian economists) cannot be avoided even if no fiduciary media (fiat money) is issued. Mises himself holds increase in commodity money itself as one of the "three tendencies toward a lowering of the gross market rate of interest. ... one was the outgrowth of the steady increase in the quantity of commodity money." [Mises 2010 June, Mises Daily Articles] 
However, the interest policy of the private banks also will cause more pandemonium than it would be if central bank pursues the interest policy. Hayek wrote, "There will of course always be a strong temptation for any bank to try and expand the circulation of its currency by lending cheaper than competing banks; but it would soon discover that, insofar as the additional lending is not based on a corresponding increase of saving, such attempts would inevitably rebound and hurt the bank that over-issued. While people will no doubt be very eager to borrow a currency offered at a lower rate of interest, they will not want to hold a larger proportion of their liquid assets in a currency of the increased issue of which they would soon learn from various reports and symptoms." [Hayek (1976) 1990, p. 63]

"Above all, everybody indebted in the currencies for which a higher rate of interest has to be paid will try to borrow cheap in order to acquire currencies in which he can repay the more burdensome loans. And all the banks that have not reduced their lending rate will promptly return to the bank that lends more cheaply all of its currency they receive. The result must be the appearance on the currency exchange of an excess supply of the over issued currency, which will quickly bring about a fall in the rate at which it can be exchanged into the others. And it will be at this new rate that commodity prices normally quoted in other currencies will be translated into the offending currency; while, as a result of its over-issue, prices normally quoted in it will be immediately driven up. The fall in the market quotation and the rise of commodity prices in terms of the offending currency would soon induce habitual holders to shift to another currency. The consequent reduction in the demand for it would probably soon more than offset the temporary gain obtained by lending it more cheaply. If the issuing bank nevertheless pursued cheap lending, a general flight from the currency would set in; and continued cheap lending would mean that larger and larger amounts would be dumped on the currency exchange.” [Hayek (1976) 1990, pp. 63-64]

Hazlitt writes, "The new credit plus competition causes them to lower their interest rates. The lower interest rates tempt more firms to borrow, because the lower costs of borrowing make more projects seem profitable than seemed profitable before.” [Hazlitt 1979, pp. 259-66]

Thus, contrary to the expectations of the Austrian School that in the free market private banks will maintain natural rate of interest and that quantity of money-issue will be restricted to the commoditymoney, there will be a tendency of the private banks to lower interest rate to the extent in which their money will be issued and lent to the maximum amount.

\section{Assessment of the Austrian theory that the Government and the Central Bank should be deprived of their monopoly in money creation}

Mises argues, "Recourse to inflation may provide the government with the funds which it could neither collect by taxation nor borrow from the savings of the public because the people and its parliamentary representatives objected." [Mises 1953, p. 428] However, Mises is wrong. Government has no other source than collecting tax and borrowing money by selling bonds. The government can neither create money nor command anybody (like the central bank) to issue or print money for itself.

Hayek thought, "What is so dangerous and ought to be done away with is not governments' right to issue money but the exclusive right to do so and their power to force people to use it and to accept it at a particular price. ... All history contradicts the belief that governments have given us a safer money than we would have had without their claiming an exclusive right to issue it." [Hayek 1976, p. 16] However, Hayek is wrong. Government does not create money. Government even cannot make the central bank 
issue money because it cannot borrow from the central bank by selling bonds directly to the central bank. Government sells bonds not to the central bank but to the public.

Hayek argues that the 'interest policy' of the central bank should be abolished because central bank keeps the interest rate low "which are intended to enable it [government] to borrow cheaply a practice which has done so much harm in the past that this effect alone would seem an adequate reason why government should be kept away from the tap." [Hayek 1976, p. 107] However, Hayek is wrong. Government does not borrow money directly from the central bank. Government cannot reduce the interest rate on money lending. It sells bonds to the public at market rate of interest through Open Market Operations (OMO). Government does not increase or decrease interest rates. It is the CB that uses its various monetary tools to increase or decrease interest rates.

\section{3. Transfer of power to create money from the Central Bank (like the Federal Reserve) to the free market private banks should be done not gradually but at once}

According to Rothbard, the Federal Reserve "has wrecked our savings, distorted our currency, levied hidden redistribution of income and wealth, and brought us devastating booms and busts. ... The American economy has suffered from chronic inflation, and from destructive booms and busts, because that inflation has been invariably generated by the Fed itself. ... the very purpose of its existence [of Fed is] to cartelize the private commercial banks, and to help them inflate money and credit together, pumping in reserves to the banks, and bailing them out if they get into trouble." [Rothbard 2007, p. 145]

"There is only one way to eliminate chronic inflation, as well as the booms and busts brought by that system of inflationary credit: and that is to eliminate the counterfeiting that constitutes and creates that inflation. And the only way to do that is to abolish legalized counterfeiting: that is, to abolish the Federal Reserve System, and return to the gold standard, to a monetary system where a market-produced metal, such as gold, serves as the standard money, and not paper tickets printed by the Federal Reserve. ... It would be easy to return to gold and to abolish the Federal Reserve, and to do so at one stroke. All we need is the will. The Federal Reserve is officially a "corporation," and the way to abolish it is the way any corporation, certainly any inherently insolvent corporation such as the Fed, is abolished." [Rothbard 2007, p. 146]

Hayek argues that transfer of monetary policy from the hands of the government to the competing private money-issuers must be done not slowly but at a time ('at once' to secure desired benefit of privately issued multi-currency system). He writes, "The other important requirement of government action, if the transition to the new order is to be successful, is that all the required liberties be conceded at once, and no tentative and timid attempt be made to introduce the new order gradually, or to reserve powers of control 'in case anything goes wrong'.

The possibility of free competition between a multiplicity of issuing institutions and the complete freedom of all movements of currency and capital across frontiers are equally essential to the success of the scheme. Any hesitant approach by a gradual relaxation of the existing monopoly of issue would be certain to make it fail. People would learn to trust the new money only if they were confident it was completely exempt from any government control. Only because they were under the sharp control of competition could the private banks be trusted to keep their money stable. Only because people could freely choose which currency to use for their different purposes would the process of selection leads to the good money, prevailing. Only because there was active trading on the currency exchange would the issuing banks be warned to take the required action in time. Only because the frontiers were open to the movement of currency and capital would there be assurance of no collusion between local institutions to mismanage the local currency. And only because there were free commodity markets would stable average prices 
mean that the process of adapting supply to demand was functioning." [Hayek (1976) 1990, pp. 122123, Italics added]

Rothbard explained the process how the power of the money creation can be taken away from the central bank. Rothbard suggested that the outstanding government debt of $\$ 345$ billion as of April 6, 1994, to the Fed should be cancelled. "This act would immediately reduce the taxpayers' liability for the public debt by $\$ 345$ billion. And indeed, why in the world should taxpayers be taxed by the U.S. Treasury in order to pay interest and principal on bonds held by another arm of the federal government - the Federal Reserve? The taxpayers have to be sweated and looted, merely to preserve the accounting fiction that the Fed is a corporation independent of the federal government. ... "Other Fed Assets," whether they be loans to banks, or buildings owned by the Fed, can be scrapped as well, although perhaps some of the assets can be salvaged. Treasury currency, simply old paper money issued by the Treasury, should quickly be canceled as well; and SDR's ( $\$ 8$ billion) were a hopeless experiment in world governmental paper that Keynesians had thought would form the basis of a new world fiat paper money. These two should be immediately canceled. ... \$6 billion are Treasury deposits with the Fed that should be canceled. That leaves the Federal Reserve with $\$ 11$ billion of gold stock to set off against $\$ 404$ billion in Fed liabilities." [Rothbard 2007, pp. 147-148]

This $\$ 11$ billion consists of 260 million ounces of gold; the price of gold being $\$ 42.22$ an ounce.

"This has been an absurd undervaluation on its face, considering that the gold price on the world market has been varying from $\$ 350$ to $\$ 380$ an ounce in recent years. ... If we wish to revalue gold so that the 260 million gold ounces can pay off $\$ 404$ billion in Fed liabilities, then the new fixed value of gold should be set at $\$ 404$ billion divided by 260 million ounces, or $\$ 1555$ per gold ounce. If we revalue the Fed gold stock at the "price" of $\$ 1555$ per ounce, then its 260 million ounces will be worth $\$ 404$ billion. Or, to put it another way, the "dollar" would then be defined as 1/1555 of an ounce." [Rothbard 2007, P 149]

"Once this revaluation takes place, the Fed could and should be liquidated, and its gold stock parceled out; the Federal Reserve Notes could be called in and exchanged for gold coins minted by the Treasury. In the meanwhile, the banks' demand deposits at the Fed would be exchanged for gold bullion, which would then be located in the vaults of the banks, with the banks' deposits redeemable to its depositors in gold coin. In short, at one stroke, the Federal Reserve would be abolished, and the United States and its banks would then be back on the gold standard, with "dollars" redeemable in gold coin at $\$ 1555$ an ounce. Every bank would then stand, once again as before the Civil War, on its own bottom." [Rothbard 2007, pp. 149-150]

"One great advantage of this plan is its simplicity, as well as the minimal change in banking and the money supply that it would require. Even though the Fed would be abolished and the gold coin standard restored, there would, at this point, be no outlawry of fractional-reserve banking. The banks would therefore be left intact, but, with the Federal Reserve and its junior partner, federal deposit insurance, abolished, the banks would, at last, be on their own, each bank responsible for its own actions. There would be no lender of last resort, no taxpayer bailout. On the contrary, at the first sign of balking at redemption of any of its deposits in gold, any bank would be forced to close its doors immediately and liquidate its assets on behalf of its depositors. A gold-coin standard, coupled with instant liquidation for any bank that fails to meet its contractual obligations, would bring about a free banking system so "hard" and sound, that any problem of inflationary credit or counterfeiting would be minimal. It is perhaps a "second-best" solution to the ideal of treating fractional-reserve bankers as embezzlers, but it would suffice at least as an excellent solution for the time being, that is, until people are ready to press on to full 100 percent banking." [Rothbard 2007, pp. 150-151] 


\section{Assessment of the plan of dissolving the central bank}

It would be more desirable not only if the debt of the government could be cancelled but also if government would not need to borrow money at all. Austrian economists have no idea how government will get sufficient funds to run the government without borrowing money or without a deficit budget. However, the central bank does not buy government debts directly from the government. Government sells bonds to the non-government sector (excluding the central bank). Therefore, cancellation of government debt will deprive those who have bought government debt instruments (government bonds) of their money. People will face huge loss if the government bonds are not redeemed by the government. If government debt is cancelled, people will no longer buy government bonds and the government will not be able to make deficit budget any more.

Again, cancellation of SDRs ( $\$ 8$ million) will lead a loss of foreign commodity worth $\$ 8$ million to the country. However, overvaluing of gold ounces to $\$ 1555$ while the market value varies from $\$ 350$ to $\$ 380$, will also create a serious problem. The gold producers, merchants, jewelers and individual holders of gold will be profited by $\$ 1555$ divided by $\$ 350$ or $\$ 380$ times. The Austrian School of Economics advocates that price of any commodity should be determined by the market forces of demand and supply. However, in this case they themselves are favoring arbitrary overvaluation of gold. While this proposal may well solve the dissolution of the central bank; it will enrich gold-holders disproportionately throughout the country and abroad.

Besides, what the private banks (now independent of any superior authority like the central bank) will do in face of constant increasing demand for money; because demand for money is always increasing due to increasing expansion of economic activities. Will they again overvalue their existing gold to meet the increasing demand for money? In that case, same thing will happen; banks will be profited at the cost of its clients (depositors and borrowers). The Austrian School is very much against this process; they feel justly that money (or more value) should not be created fraudulently through embezzlement or counterfeiting or against nothing. The creation of more money (more value) against fewer reserves is unethical and fraudulent; but same thing will happen. The reserve of gold will remain as it is; the volume or amount of money (value) will go on increasing. This is exactly what the banks are doing (according to the Austrian School) at present under fractional reserve banking; and what the Austrian School tries to eliminate by abolishing the central bank.

\subsection{Austrian School's description of how private banks will behave in the free banking system}

Hayek explains how the private banks are expected to function or behave in the new system of private money creation and private banking. "The apparent profitability of this business would obviously attract competitors." [Hayek Oct 2014] "Clearly a number of competing issuers of different currencies would have to compete in the quality of the currencies they offered for loan or sale. Once the competing issuers had credibly demonstrated that they provided currencies more suitable to the needs of the public than government has ever provided, there would be no obstacle to their becoming generally accepted in preference to the governmental currencies - at least in countries in which government had removed all obstacles to their use." [Hayek (1976) 1990, p. 52] "a competing institution issuing its distinctive currency will always be able to regulate its value by controlling its quantity so as to make it more attractive to people than other currencies." [Hayek (1976) 1990, p. 54]

Hayek says, "we shall concentrate on whether an issuing bank in competition with other issuers of similar currencies will have the power to control the quantity of its distinctive issue so as to determine the value it will command in the market. Hayek (1976) 1990, p. 59] "In order to retain control over its outstanding 
circulation, it will on the whole have to confine its lending to relatively short-time contracts so that, by reducing or temporarily stopping new lending, current repayments of outstanding loans would bring about a rapid reduction of its total issue." [Hayek (1976) 1990, p. 59]

"Perhaps I ought to spell out here in more detail how an issuing bank would have to proceed in order to keep the chosen value of its currency constant. The basis of the daily decisions on its lending policy (and its sales and purchases of currencies on the currency exchange) would have to be the result of a constant calculation provided by a computer into which the latest information about commodity prices and rates of exchange would be constantly fed as it arrived." [Hayek (1976) 1990, p. 60]

"The essential point which I cannot emphasize strongly enough is that we would get for the first time a money where the whole business of issuing money could be effected only by the issuer issuing good money. He would know that he would at once lose his extremely profitable business if it became known that his money was threatening to depreciate. He would lose it to a competitor who offered better money." [Hayek April2019, p.4]

Hayek explains how the private banks will control the quantity of their money issue thus: "in conditions of severe uncertainty or alarm about the future, even very low rates of interest cannot prevent a shrinking of a bank's outstanding loans. What could a bank issuing its own distinct currency do when it finds itself in such a situation, and commodity prices in terms of its currency threaten to fall? ... [In such a circumstance of rising prices of money], There would of course be no difficulty in placing additional money at a time when people in general want to keep very liquid. The issuing bank, on the other hand, would not wish to incur an obligation to maintain by redemption a value of its currency higher than that at which it had issued it. To maintain profitable investments, the bank would presumably be driven to buy interest-bearing securities and thereby put cash into the hands of people looking for other investments as well as bring down the long-term rates of interest, with a similar effect. An institution with a very large circulation of currency might even find it expedient to buy for storage quantities of commodities represented in the index that tended to fall particularly strongly in price." [Hayek (1976) 1990, p. 99] This means, Hayek allows that to avoid deflationary effects of limited money-supply, banks must increase money supply. However, Hayek wants to abolish central bank because the central banks are prone to inflate money for fighting deflation.

Hayek argues that news papers and the internal computing system of every private bank will constantly inform the bankers about even minor changes in the value of their currencies and the price index of the commodities so that they may change the quantity of money issue to keep values of both their currencies and the commodities constant. "The papers [News papers] would probably print a table daily, not only of the current rates of exchange between the currencies but also of the current value, and the deviation of each of the currencies likely to be used by their readers from the announced standard of value in terms of commodities." [Hayek (1976) 1990, p. 54]

Hayek explains, "All executive officers of the issuing bank would be guided in their decisions about lending and the purchase or sale of currencies or other assets by a guide number, the current value of which a computer would constantly flash before them.

The guide number would be, in effect, an appropriately weighted average of the monetary prices probably of raw materials and internationally traded foodstuffs, taken in the first instance in terms of the currencies in which they were traded, and converted at the current rate of exchange.

In other words, it would be an index number continuously computed on the basis of the latest arrived price and exchange quotation. If the basis of this index number were, say, 1,000, a rise to 1,003 would 
instantly inform all officers of the bank that they would curtail their lending and purchases slightly. Similarly, a fall to, say, 998 would tell them that they could relax slightly.

The same information would of course be used by the market and the media, with the result that any deviation from the announced standard would rapidly be brought to public notice.

Since the assets of any such bank would consist chiefly of short term loans in terms of its own stable currency, there should be no problem about its being able to control amounts outstanding. For purposes of instant liquidity it would have to hold a certain limited reserve in other currencies, but its situation would be exactly that of all other banks that have ever existed - namely, that it could not meet all its demand obligations if they were required at the same time." [Hayek Oct. 2014, Italics added]

Ebeling says there will be different types of private banks in the free market system. He writes, "Along the rest of the spectrum would be various fractional-reserve banks at which lower or no fees would be charged for serving as a warehousing facility for deposited commodity money. Their checking accounts might offer different interest payments depending on the fractional-reserve basis on which they were issued and on the degree of risk or uncertainty concerning the banks' ability to redeem all deposits immediately under exceptional circumstances.

Some banks might offer both types: they might issue some bank notes and checking accounts that were guaranteed to be 100 percent redeemable on the basis of commodity money deposited against them; and they might issue other bank notes and checking accounts that, under exceptional circumstances, were not 100 percent redeemable.

And these banks might offer "option clauses" stipulating that if any designated notes or checking accounts were not redeemed on demand for some limited period of time, the note and account holder would receive a compensating rate of interest for the inconvenience and cost to himself." [Ebeling 2012 Aug, p. 10, Italics added]

Hayek suggests what actions the money-issuing banks should take if the commercial banks that do not issue money but acts as the intermediary banks, if commercial banks issue unlimited credit money that have to converted into the money of money-issuing banks. Hayek suggests, "To achieve this the original issuer of a currency with a certain label would have to anticipate the effects of the over-issue of such a parasitic currency (or any other currency claiming to maintain a value equal to its own) and ruthlessly to refuse to buy it at par even before the expected depreciation manifests itself in the rise of some commodity prices in terms of that other currency." [Hayek (1976) 1990, p. 65] "What the original issuer of "such a currency could do and would have to do is not to repeat the mistakes governments have made; as "a. result of which control of these secondary or parasitic issues has slipped from their hands. It must make clear that it would not be prepared to bail out secondary issuers by supplying the 'cash' (i.e. the original notes) they will need to redeem their obligations." [Hayek (1976) 1990, p. 65] "This also shows that the proposed reform requires a complete change in the practices not only of the banks which take up the business of issuing currency but also of those which do not. For the latter [commercial banks] could no longer rely on being bailed out by a central bank if they could not meet from their own reserves their customers' demands for cash - not even if they chose to keep their accounts in terms of the currency issued by a still existing governmental central bank which, to maintain its circulation, would have to adopt the practices of the other issuing banks with which it competed.” [Hayek (1976) 1990, p. 92]

The competition and the fear of falling will compel the private bankers to keep their issuance of money in check. Mises thought that "Since the overissuance of fiduciary media on the part of one bank . . . increases the amount to be paid by the expanding bank's clients to other people, it increases 
concomitantly the demand for the redemption of its money-substitutes. It thus forces the expanding bank back to a restraint." [Mises 1996, p. 444]. Arthur Seldon writes, "he [Hayek] is arguing that the attempt for the past 50 years to depend on benevolence in government to manage money has failed and that the solution must lie in the self-interest of monetary agencies that will suffer by losing their livelihood if they do not supply currencies that users will find dependable and stable." [Hayek (1976) 1990, Preface, p 11] Hayek argues that "there is no reason to doubt that private enterprise whose business depended on succeeding in the attempt could keep stable the value of a money it issued." [Hayek (1976) 1990, p. 36]

\section{Assessment of Austrian School's description of how private banks will behave in the free banking system}

It may be such that banks may not accept the check or money issued by other banks. Thus economic activities will become cumbersome and sluggish.

Hayek expects, "In this condition the value of the currency issued by one bank would not necessarily be affected by the supplies of other currencies by different institutions (private or governmental). And it should be in the power of each issuer of a distinct currency to regulate its quantity so as to make it most acceptable to the public - and completion would force him to do so." [Hayek (1976) 1990, p. 51]

However, Hayek himself gave an example that a bank (in this case central bank) must restrict (reduce) its issuance of (lending) money to the value of its money constant. He writes, "It is not very likely that it [government] would succeed, because to prevent an accelerating depreciation of its currency it would have to respond to the new currencies by a rapid contraction of its own issue." [Hayek (1976) 1990, p. 53] Similar situation may occur in case of any money-issuing private bank. The apparent profitability of this business would obviously attract competition" [Hayek, 2014, Oct.] And "The competition between the issuing banks would be made very acute by the close scrutiny of their conduct by the press and at the currency exchange. [Hayek (1976) 1990, p. 53].

Besides, Hayek himself asserts that "in conditions of severe uncertainty or alarm about the future, even very low rates of interest cannot prevent a shrinking of a bank's outstanding loans." [Hayek (1976) 1990, p. 99] and that "For purposes of instant liquidity it would have to hold a certain limited reserve in other currencies, but its situation would be exactly that of all other banks that have ever existed - namely, that it could not meet all its demand obligations if they were required at the same time." [Hayek Oct. 2014, Mises Daily Articles] Therefore, in a competitive market, it is obvious that some banks will prosper and some bank will fail. Thus, the customers of the bankrupt banks will lose all of their savings in that bank.

"In order to retain control over its outstanding circulation, it will on the whole have to confine its lending to relatively short-time contracts so that, by reducing or temporarily stopping new lending, current repayments of outstanding loans would bring about a rapid reduction of its total issue." [Hayek (1976)1990, p. 59] However, confining the lending activities into only short-term or stopping or reducing loan amount will discourage long-term projects. It will hinder growth.

Ebeling argues, "Their checking accounts might offer different interest payments depending on the fractional-reserve basis on which they were issued and on the degree of risk or uncertainty concerning the banks' ability to redeem all deposits immediately under exceptional circumstances." [Ebeling 2012, p. 10] However, Customers will be confused and sometimes may even lose because of the differences of interest rates among different money-issuing and lending banks. 
However, Hayek is not sure whether the public and the bank will act according to what Hayek expects them to perform. Hayek wrote, "I am not sure that private enterprise would adopt the manner of performing the task I have suggested, but I am inclined to think that, by its habitual procedure of selecting the most successful, it would in time throw up better solutions to these problems than anyone can foresee today." [Hayek (1976) 1990, p. 102]

\subsection{How people will accept concurrent moneys issued by private banks}

Hayek writes, "it is my thesis that the public would select from a number of competing private currencies a better money than governments provide, I must now examine the process and the criteria by which such a selection would take place. ... We must not, of course, assume that people will at once act rationally in a new situation. But, if not by insight, they would soon learn by experience and imitation of the most successful what conduct best serves their interests. A major change like the one considered here might at first cause much uncertainty and confusion. Yet I do not think there is much reason to doubt that people would soon discover what rational consideration could have told them at once. Whether in practice the process would be fast or slow may differ from country to country." [Hayek (1976) 1990, p. 66]

"Given the diversity in people's tastes and preferences, the differing degrees of risk people are willing to bear for a promised interest return on their money, and the variety of market situations in which different types of monetary and financial instruments might be most useful for certain domestic and international transactions, it probably would be the case that a spectrum of financial institutions would come into existence side by side. At one end of this spectrum would be 100 percent reserve banks that guaranteed complete and immediate redemption of all commodity money deposits, even if every depositor were to appear at that bank within a very short period of time." [Ebeling 2012 Aug, p. 10]

Hayek argues that even if general public does not understand the complexity involved with the multicurrency system there will be no problem. He writes, "There is no reason to be concerned about the effects of such an arrangement on ordinary men who know neither how to handle nor how to obtain strange kinds of money. So long as the shopkeepers knew that they could turn it instantly at the current rate of exchange into whatever money they preferred, they would be only too ready to sell their wares at an appropriate price for any currency." [Hayek (1976) 2009, p. 19]

The people will have trust in the newly formed private banks as they have trusted the Central Banks and other banks so far. Hayek writes, "The kind of trust on which private money would rest would not be very different from the trust on which today all private banking rests (or in the United States rested before the governmental deposit insurance scheme!). People today trust that a bank, to preserve its business, will arrange its affairs so that it will at all time be able to exchange demand deposits for cash, although they know that banks do not have enough cash to do so if everyone exercised his right to demand instant payment at the same time." [Hayek (1976) 1990, pp. 48-49]

Hayek argues that people should be free to choose any money they think to be stable than other monies. He writes, "there is no reason whatsoever why people should not be free to make contracts, including ordinary purchases and sales, in any kind of money they choose, or why they should be obliged to sell against any particular kind of money." [Hayek (1976) 2009, p. 17]

Mises argue that "The public will have to learn to select among a variety of monies, and to choose those which are good." [Hayek 2019 April, p.5] "[W]e [the people] can follow statistically the progress of variations in purchasing power from month to month. [Mises 1980, p. 222] 


\section{Assessment of how people will accept moneys issued by private banks}

The above narration shows that people will be puzzled in deciding which currency they should hold and which currency others will accept. There is every possibility that sometimes they will gain and sometimes they will lose because of the uncertainty of rise and fall of value of one currency against other currencies.

The people will always be in an uncertainty and panicked situation because their money will not be secured against any bank failure or any change in the prices of money. Economic activities cannot run smoothly where the value of money is always unstable.

\subsection{What the nature of concurrent currencies issued by competing private banks will be}

One currency, among different competing currencies, will emerge as a single standard for the rest of the currencies in circulation

\footnotetext{
"What money will the public prefer if it can choose among several kinds, differing in character and stability?
}

The answer will depend upon the success or failure of the competing currencies, which may be based on different standards. That is, there could be differences between the different commodities to which the monetary index is pegged, differences in the degree of stability and differences in bank growth.

But once the public shows preference for a particular standard (or perhaps several standards), nothing can prevent other banks from basing their own currency (although under another name) on that same standard.

I anticipate that ultimately a single or a very few standards would prevail, certainly in large regions and perhaps worldwide. I also anticipate that currencies aiming at the same standards would be issued under different names by many different banks, which would continue to compete as to the reliability of their faithfulness to those standards and as to all the other services they would offer users of their currency." [Hayek Oct 2014, Italics added]

Privately issued concurrent currencies will give the public better money than the money issued by the government

"As a result I am more convinced than ever that if we ever again are going to have a decent money, it will not come from government: it will be issued by private enterprise, because providing the public with good money which it can trust and use can not only be an extremely profitable business; it imposes on the issuer a discipline to which the government has never been and cannot be subject. It is a business which competing enterprise can maintain only if it gives the public as good a money as anybody else." [Hayek April 2019, p.1]

The currency having constant purchasing power will be more accepted than other currencies by the people

Hayek explains what "the effects of competition" will be thus:

"It seems to me to be fairly certain that 
(a) a money generally expected to preserve its purchasing power approximately constant would be in continuous demand so long as the people were free to use it,-

(b) with such a continuing demand depending on success in keeping the value of the currency constant one could trust the issuing hanks to make every effort to achieve this better than would any monopolist who runs no risk by depreciating his money,-

(c) the issuing institution could achieve this result by regulating the quantity of its issue,. and

(d) such a regulation of the quantity of each currency would constitute the best of all practicable methods of regulating the quantity of media of exchange for all possible purposes." [Hayek (1976) 1990, p. 52]

The Austrian school argues that private banks will be afraid of issuing fiat money, because, increase in fiat money will cause price-inflation and the value of their money will face devaluation. The Austrians think that no private banker will want to face devaluation of their moneys. Thus, they argue that private banks will issue only commodity-money. And, therefore, no depression or recession will occur in future.

\section{Hayek is confused whether people will accept stable money more than the money that is more liquid or vice versa}

" it will be important to keep in mind that different kinds of money can differ from one another in two distinct although not wholly unrelated dimensions: acceptability (or liquidity) and the expected behaviour (stability or variability) of its value. The expectation of stability will evidently affect the liquidity of a particular kind of money, but it may be that in the short run liquidity may sometimes be more important than stability, or that the acceptability of a more stable money may for some reason be confined to rather limited circles. . [Hayek (1976) 1990, p. 57]

\section{Government currency will be depreciated in the competition with privately issued concurrent currencies}

"It would seem that in this situation sheer desire for gain would produce a better money than government has ever produced." [Hayek (1976) 1990, p. 51] "The appearance and increasing use of the new currencies would, of course, decrease the demand for the existing national ones and, unless their volume was rapidly reduced, would lead to their depreciation." [Hayek (1976) 1990, p. 53]

"Successful pursuit of such a policy would mean that if the national currency into which the private one was legally convertible continued to be inflated, the private currency would come to float higher and higher. From the beginning it would have been valued more highly than any of the currencies in which it was redeemable at the option of the holder, simply because thanks to that option it was less risky.

But as official currencies continue to depreciate, the difference would steadily grow, and with it public awareness of the advantages of stable currency. " [Hayek Oct 2014, Italics added]

To Hayek, "It seems not unlikely that gold would ultimately re-assert its place as 'the universal prize in all countries, in all cultures, in all ages ... if people were given complete freedom to decide what to use as their standard and general medium of exchange - more likely, at any rate, than as the result of any organized attempt to restore the gold standard." [Hayek (1976) 2009, p. 20] Hayek wrote, "the changes in the supply of basic money which its [gold standard] mechanism secured were on the whole in the right direction." [Hayek 1943, p. 161] 
However, due to "its [gold standard] incompatibility with a policy of credit expansion" [Mises 1953, p. 421], Hayek apprehends that bankers will begin to issue fiat money so that supply of money can be increased to meet the increasing demand for money.

"It may be that, with free competition between different kinds of money, gold coins might at first prove to be the most popular. But this very fact, the increasing demand for gold, would probably lead to such a rise (and perhaps also violent fluctuations) of the price of gold that, though it might still be widely used for hoarding, it would soon cease to be convenient as the unit for business transactions and accounting. There should certainly be the same freedom for its use, but I should not expect this to lead to its victory over other forms of privately issued money, the demand for which rested on its quantity being successfully regulated so as to keep its purchasing power constant." [Hayek (1976) 1990, pp. 130-131]

He [Hayek] writes, "It would therefore now be possible, if it were permitted, to have a variety of essentially different monies. They could represent not merely different quantities of the same metal, but also different abstract units fluctuating in their value relatively to one another. In the same way, we could have currencies circulating concurrently throughout many countries and offering the people a choice." [Hayek (1976) 1990, p. 32]

"It is however, clearly not practicable to allow tokens with the same name and readily exchangeable against each other to be issued competitively, since nobody would be in a position to control their quantity and therefore be responsible for their value. The question we have to consider is whether competition between the issuers of clearly distinguishable kinds of currency consisting of different units would not give us a better kind of money than we have ever had, far outweighing the inconvenience of encountering (but for most people not even having to handle) more than one kind." [Hayek (1976) 1990, p. 51]

"Individual consumers would probably be content to be paid in any generally accepted money that did not depreciate noticeably. But the large manufacturing firms and trading corporations would choose money that made a reliable capital accounting possible, minimized as much as possible uncertainty about the future movement of particular prices, and was internationally acceptable. Eventually a common commodity standard would develop, represented by a number of different specified currencies." [Hayek Oct 2014, Mises Daily Articles]

\section{Assessment of nature of concurrent currencies in the free private banking system}

"Competition is needed in order to ensure efficiency and high quality in every market. Hayek shows that there is no reason to deny competition in the money market. In short, those currencies that lose value more quickly will be displaced by others in the market which better serve its function. The competitive process thus becomes a market-driven obstacle to inflation and an institutional guarantee against instability." [Ravier No date]

Arthur Seldon writes, "The advantages that Professor Hayek claims for competitive currencies are not only that they would remove the power of government to inflate the money supply but also that they would go a long way to prevent the destabilising fluctuations that government monopoly of money has precipitated over the last century of 'trade cycles'." [Hayek (1976) 1990, Preface, p 9]

From the above narration it is clear that private banks will compete among themselves to survive and there is every possibility that some private banks will perform poorly than others and will certainly fall. The failure of any private bank will cause huge losses not only of its own but also of its clients. 


\subsection{Austrian School's explanation of money-substitute, fiduciary media (Fiat Money) and circulation credit}

"Historically, banks have issued two types of money-substitutes: money certificates, for which the bank "keeps against the whole amount of money substitutes a reserve of money proper," and fiduciary media, which is "the amount of substitutes which exceeds the reserve" [Mises 1998, p. 430]

Sieron writes, "Commodity money means "a medium of exchange which is either a commercial commodity or a title thereto" [Hoppe 1994, p. 49], while fiat money is a medium of exchange which is not the commodity money" [Sieron Undated, p.2]

Issuing fiduciary media permits credit expansion. Mises wrote, A bank "can now not only grant commodity credit, but also circulation credit, that is, credit granted out of the issue of fiduciary media." The result of an issue of fiduciary media is a reduction in money's purchasing power and the rate of interest. [Mises 1998, pp. 430-31] Then, Fiduciary media becomes the source of credit expansion and credit expansion is an integral part of the trade cycle. Mises wrote, "The term credit expansion has often been misinterpreted, it is important to realize that commodity credit cannot be expanded. The only vehicle of credit expansion is circulation credit." [Mises 1998, p. 431] Mises wrote, "Credit expansion is present only if credit is granted by the issue of an additional amount of fiduciary media." [Mises 1998, p. 431]

Mises wrote: "The notion of "normal" credit expansion is absurd. Issuance of additional fiduciary media, no matter what its quantity may be, always sets in motion those changes in the price structure the description of which is the task of the theory of the trade cycle." [Mises 1998 p. 439]

Mises explains that 'circulation credit is the sum of fiduciary media (money issued in excess of commodity money backing) lent as credit and the credit lent to the customers by commercial banks. Mises writes, "circulation credit can be granted not only by the issue of banknotes in excess of the banks' holding of cash reserves, but also by creating bank deposits subject to check in excess of such reserves (checkbook money, deposit currency). ... deposits payable on demand can also be used as a device of credit expansion. ... It is enough to stress the point that all that refers to credit expansion is valid for all varieties of credit expansion no matter whether the additional fiduciary media are banknotes or deposits." [Mises 2010 June 11, Mises Daily Articles]

"This distinction between money-certificates and fiduciary media is important because issuing the latter results in credit expansion, the very force Mises was interested in curbing." [Herbener, p. 87]

"Credit expansion initially can produce a boom. But such a boom is bound to end in a slump, in a depression. What bring about the recurrence of periods of economic crises are precisely the reiterated attempts of governments and banks supervised by them to expand credit in order to make business good by cheap interest rates. [Mises 1953, p. 422]

"Barred from issuing additional fiduciary media, banks could play no role in generating a boom-bust cycle, even if they had existing fiduciary media outstanding. With the government impetus for inflation removed from the monetary system and 100 percent reserve banking, inflation, the main enemy in monetary affairs, is at last restricted as much as possible." [Herbener, pp. 89-90]

"Mises held that the major drawback of issuing fiduciary media was the resulting business cycle and, once his views were fully developed, he held that this drawback alone was sufficient to outweigh any advantages fiduciary media may have." [Herbener, P. 83]

Hayek pleaded for the abolition of the central bank because he thinks that the support of the central bank, to the commercial banks by adjusting the commercial bank's demand for reserve/ deposit to meet the 
withdrawal demand of the customers, is the real cause of credit expansion that causes money-inflation and consequently price-inflation. He writes, "some of the classic functions of central banks, such as that of acting as 'lender of last resort' or of 'holder of the ultimate reserve', might still be required. The need for such an institution is, however, entirely due to the commercial banks incurring liabilities payable on demand in a unit of currency which some other bank has the sole right to issue, thus in effect creating money redeemable in terms of another money. This, as we shall have still to consider, is indeed the chief cause of the instability of the existing credit system, and through it of the wide fluctuations in all economic activity. Without the central bank's (or the government's) monopoly of issuing money, and the legal tender provisions of the law, there would be no justification whatever for the banks to rely for their solvency on the cash to be provided by another body.” [Hayek (1976) 1990, pp. 105-106]

\section{Assessment}

Mises is wrong. Both commodity money (gold or silver money) or money certificate and fiduciary money can enter economy for circulation only through lending by the money-issuing authority (whether it is the central bank, a commercial bank or a private bank) to the creditworthy borrowers. Borrowers are bound to repay the value both of the commodity money (or its certificate) and of the fiduciary media along with the interest accrued on them. Borrowers cannot distinguish between the commodity certificate and the fiduciary media. Mises wrote, "As a rule, it is not possible to ascertain whether a concrete specimen of money-substitute is a money-certificate or a fiduciary medium." [Mises1998, p. 430] Therefore, it is impossible to ascertain whether the money issuing bank issues any fiduciary media or not. Therefore, it is also not possible to know whether the money that is lent is 'normal credit' or 'circulation credit'. Money has to be lent to meet the increasing demand for money. Stopping or reduction in lending will hamper the economic growth. Therefore, if lending of money increase inflation, then it a systemic defect of the economy. Restricting or reducing in lending money (commodity money, fiat money and credit money) cannot solve the problem of inflation or recession; it will only retard the economic activity.

However Mises gives importance not on stopping of issuance of fiduciary money but on customers' satisfaction in the banking system that issues fiduciary media. In a free banking system where anybody can issue money, Mises wrote, "no bank can content itself with issuing fiduciary media only; it must keep a reserve against the total amount of money-substitutes issued and thus combine issuing fiduciary media and money-certificates." [Mises 1998, p. 436]

Mises wrote, the client's confidence in the bank "is an essential feature or weakness of the business of issuing fiduciary media and granting circulation credit. . . . No system of reserve policy and no reserve requirements as enforced by the laws, can remedy it" [Mises 1998, p. 436]

Both Mises and Hayek allowed the private banks in the free banking system not to reserve any commodity because of storage problem and to create and lend fiduciary media (fiat money) if the banks can manage to keep the purchasing power of money constant. However, "Issuing the latter (fiduciary media) results in credit expansion, the very force Mises was interested in curbing." [Herbener, p.87]

\subsection{Austrian School's explanation why information about the changes in the Quantity of Money- supply is not necessary to determine the Consumer Price Index}

"The index-number method is a very crude and imperfect means of "measuring" changes occurring in the monetary unit's purchasing power. As there are in the field of social affairs no constant relations between magnitudes, no measurement is possible and economics can never become quantitative." [Mises 1953, p. 419] 
"My fundamental objection to the adequacy of the pure quantity theory of money is that, even with a single currency in circulation within a territory, there is, strictly speaking, no such thing as the quantity of money, and that any attempt to delimit certain groups of the media of exchange expressed in terms of a single unit as if they were homogeneous or perfect substitutes is misleading even for the usual situation. This objection becomes of decisive importance, of course, when we contemplate different concurrent currencies." [Hayek (1976) 1990, p. 81]

"The quantity theory presupposes, of course, that there is only one kind of money in circulation within a given territory, the quantity of which can be ascertained by counting its homogeneous (or nearhomogeneous) units." [Hayek (1976) 1990, p. 76]

However, Hayek argues, that the quantity theory of money is of no use in a multi-currency system. He writes, "if we assume that issuers of currency continually compete with one another for additional users of their currency, we cannot also assume, as the quantity theory can assume with some justification with respect to a currency of a single denomination, that there exists a fairly constant demand for money in the sense that the aggregate value of the total stock will tend to be approximately constant." [Hayek (1976) 1990, p. 77] He writes, "The decisive consideration to keep in mind for our present purpose is that in multi-currency system there is no such thing as the magnitude of the demand for money. There will be different demands for the different kinds of currency; but since these different currencies will not be perfect substitutes, these distinct demands cannot be added up into a single sum. There may be little demand for (but large supply of) depreciating currencies, there will, we hope, be an equality of demand and supply for stable currencies (which is what will keep their values stable), and a large demand for (but little supply of) appreciating currencies. Though, so long as there exists a free market for currencies, people will be prepared to sell (at some price) for any currency, they will not be prepared to hold any currency; and the character of the available substitutes would affect the demand for any particular currency. There would therefore be no single quantity the magnitude of which could be said to be decisive for the value of money. [Hayek (1976) 1990, pp. 77-78]

Hayek explains the chief defects of quantity theory of money thus: "Its [Quantity theory of Money] chief defect in any situation seems to me to be that by its stress on the effects of changes in the quantity of money on the general level of prices it directs all-too exclusive attention to the harmful effects of inflation and deflation on the creditor debtor relationship, but disregards the even more important and harmful effects of the injections and withdrawals of amounts of money from circulation on the structure of relative prices and the consequent misallocation of resources and particularly the misdirection of investments which it causes." [Hayek (1976) 1990, p. 80]

"Monetary management cannot aim at a particular predetermined volume of circulation, not even in the case of a territorial monopolist of issue, and still less in the case of competing issues, but only at finding out what quantity will keep prices constant. No authority can beforehand ascertain, and only the market can discover, the 'optimal quantity of money'. It can be provided only by selling and buying at a fixed price the collection of commodities the aggregate price of which we wish to keep stable." [Hayek (1976) 1990, p. 81, Italics added]

According to Hayek the main defect of the quantity theory of money is that it allows money-supply to be increased and thus cause harmful effects on the economy by "prolonging and increasing it [inflation], and in the long run considerably magnify the damage it causes and particularly the suffering it produces by bringing about unemployment." [Hayek (1976) 1990, p. 82] 


\section{Assessment of the Austrian School's explanation why information about the changes in the Quantity of Money-supply is not necessary to determine the Consumer Price Index}

Hayek identifies the monetary stability with the stability of the purchasing power. However, purchasing power of money (PPM) can never be constant. Hülsmann points out: "First of all notice that the notion of "purchasing power of money" (PPM) cannot be given an impartial definition. The PPM is in fact the total array of things for which a unit of money can be exchanged. If the price of telephones increases while the price of cars drops, it is impossible to say by any impartial standard whether the PPM has increased or decreased. ... For one thing, the constituents of the price index are in need of incessant adaptation (they need to be changed) to take account of the changes in the array of goods and services offered on the market in exchange for money. Moreover, and most importantly, no such index conveys generally valid information. Different persons buy different goods; therefore, some of them might experience a rise of prices (of the prices they have to pay) while others experience a drop of (their) prices in the very same period.” [Hulsmann 2008, p. 77]

"Mises did argue ... that there is no unique, correct way to construct a price index and thus, using some price index as a measure of changes in money's purchasing power is arbitrary and the selection of which one to use is then subject to political pressure." [Herbener, p.71]

If 'purchasing power of money' or 'consumer price index' cannot be ascertained correctly or if they do not remain stable or constant, then it would also not be possible as Hayek argues that "It [money supply] can be provided only by selling and buying at a fixed price the collection of commodities the aggregate price of which we wish to keep stable.” [Hayek (1976) 1990, p. 81]

\subsection{Austrian School's opinion regarding the 'Optimal Quantity of Money' is:}

No new money supply is needed -existing money will adjust itself to the increase or decrease in demand for money

Rothbard opines that as money is primarily meant for facilitating exchange of commodities that is consumed and as money is not meant for consumption; therefore, the increase in quantity of money will not serve any useful purposes of the economy. Therefore he suggests that "once a money has been established in the market, no increase in its supply are needed" [Rothbard 2007, p. 19] Now, let us look how he explains his contention. Rothbard explains, "The total stock, or "supply," or quantity of money in any area or society at any given time is simply the sum total of all the ounces of gold, or units of money, in that particular society or region. Economists have often been concerned with the question: what is the "optimal" quantity of money, what should the total money stock be, at the present time? How fast should that total "grow"? ... In fact, the very question is absurd. ... It is because people sense the absurdity of such a question that it is virtually never raised." [Rothbard 2007, p. 18]

He continues, "But of what direct benefit is an increase in the supply of money? Money, after all, can neither be eaten nor used up in production. The money-commodity, functioning as money, can only be used in exchange, in facilitating the transfer of goods and services, and in making economic calculation possible. But once a money has been established in the market, no increases in its supply are needed, and they perform no genuine social function. As we know from general economic theory, the invariable result of an increase in the supply of a good is to lower its price. For all products except money, such an increase is socially beneficial, since it means that production and living standards have increased in response to consumer demand. If steel or bread or houses are more plentiful and cheaper than before, everyone's standard of living benefits. But an increase in the supply of money cannot relieve the natural 
scarcity of consumer or capital goods; all it does is to make the dollar or the franc cheaper, that is, lower its purchasing power in terms of all other goods and services. Once a good has been established as money on the market, then, it exerts its full power as a mechanism of exchange or an instrument of calculation. All that an increase in the quantity of dollars can do is to dilute the effectiveness, the purchasing-power, of each dollar. Hence, the great truth of monetary theory emerges: once a commodity is in sufficient supply to be adopted as a money, no further increase in the supply of money is needed. Any quantity of money in society is "optimal." Once a money is established, an increase in its supply confers no social benefit. [Rothbard 2007, pp. 19-20] "Any rate of growth can therefore be accommodated by virtually any supply of natural monies such as gold and silver." [Hulsman 2008, p. 61]

"Does that mean that, once gold became money, all mining and production of gold was a waste? No, because a greater supply of gold allowed an increase in gold's nonmonetary use: more abundant and lower-priced jewelry, ornaments, fillings for teeth, etc. But more gold as money was not needed in the economy. Money, then, is unique among goods and services since increases in its supply are neither beneficial nor needed; indeed, such increases only dilute money's unique value: to be a worthy object of exchange." [Rothbard 2007, p. 20]

\section{Assessment of the 'Optimal Quantity of Money'}

\section{It is not true that existing money supply will adjust itself to the increase or decrease in demand for money}

However, Hayek does not think that a constant quantity of money will sufficiently adjust itself for exchanging any increasing or decreasing volume of commodities. He writes, "A stable price level and a high and stable level of employment do not require or permit the total quantity of money to be kept constant or to change at a constant rate. It demands something similar yet still significantly different, namely that the quantity of money (or rather the aggregate value of all the most liquid assets) be kept such that people will not reduce or increase their outlay for the purpose of adapting their balances to their altered liquidity preferences. Keeping the quantity of money constant does not assure that the money stream will remain constant, and in order to make the volume of the money stream behave in a desired manner the supply of money must possess considerable elasticity." [Hayek (1976) 1990, p. 81]

\section{Index number of commodity-prices helps banks to regulate their policy of reducing or increasing supply of money for maintaining constant value of the money and the commodities in the market.}

Hayek argues that news papers and the internal computing system of every private bank will constantly inform the bankers about even minor changes in the value of their currencies and the price index of the commodities so that they may change the quantity of money issue to keep values of both their currencies and the commodities constant. "The papers [News papers] would probably print a table daily, not only of the current rates of exchange between the currencies but also of the current value, and the deviation of each of the currencies likely to be used by their readers from the announced standard of value in terms of commodities." [Hayek (1976) 1990, p. 54]

Hayek explains, "All executive officers of the issuing bank would be guided in their decisions about lending and the purchase or sale of currencies or other assets by a guide number, the current value of which a computer would constantly flash before them.

The guide number would be, in effect, an appropriately weighted average of the monetary prices probably of raw materials and internationally traded foodstuffs, taken in the first instance in terms of the currencies in which they were traded, and converted at the current rate of exchange. 
In other words, it would be an index number continuously computed on the basis of the latest arrived price and exchange quotation. If the basis of this index number were, say, 1,000, a rise to 1,003 would instantly inform all officers of the bank that they would curtail their lending and purchases slightly. Similarly, a fall to, say, 998 would tell them that they could relax slightly.

The same information would of course be used by the market and the media, with the result that any deviation from the announced standard would rapidly be brought to public notice." [Hayek Oct 2014, Italics added]

However, if needed supply of money must be reduced to protect money from its deflation. Hayek himself cited some examples when money supply has to be restricted to avoid deflationary effect. He writes, "The first, which produced the experience which I believe inspired the Austrian monetary theory, happened in my native country in 1879. The government happened to have a really good adviser on monetary policy, Carl Menger, and he told them, "Well, if you want to escape the effect of the depreciation of silver on your currency, stop the free coinage of silver, stop increasing the quantity of silver coin, and you will find that the silver coin will begin to rise above the value of their content in silver." And this the Austrian government did and the result was exactly what Menger had predicted." [Hayek April 2019, Mises Daily Articles, p.2]

"Exactly the same was done fourteen years later by British India. It also had had a silver standard and the depreciation of silver brought the rupee down lower and lower till the Indian government decided to stop the free coinage; and again the silver coins began to float higher and higher above their silver value. Now, there was at that time neither in Austria nor in India any expectation that ultimately these coins would be redeemed at a particular rate in either silver or gold. The decision about this was made much later, but the development was the perfect demonstration that even a circulating metallic money may derive its value from an effective control of its quantity and not directly from its metallic content. [April Hayek 2019, p.2]

Sweden was greatly worried: because it had stuck to the gold standard, it was flooded by gold from all the rest of the world that moved to Sweden which had retained its gold standard; and Swedish prices rose quite as much as prices in the rest of the world. Now, Sweden also happened to have one or two very good economists at the time, and they repeated the advice which the Austrian economists had given concerning the silver in the 1870s, "Stop the free coinage of gold and the value of your existing gold coins will rise above the value of the gold which it contains." The Swedish government did so in 1916 and what happened was again exactly what the economists had predicted: the value of the gold coins began to float above the value of its gold content and Sweden, for the rest of the war, escaped the effects of the gold inflation." [Hayek April 2019, p.2, Italics added]

\section{Supply of money also has to be increased to avoid deflation of the CPI or according to the market demand for supply of money}

Hayek explains how the private banks will control the quantity of their money issue thus: "in conditions of severe uncertainty or alarm about the future, even very low rates of interest cannot prevent a shrinking of a bank's outstanding loans. What could a bank issuing its own distinct currency do when it finds itself in such a situation, and commodity prices in terms of its currency threaten to fall? ... [In such a circumstance of rising prices of money], There would of course be no difficulty in placing additional money at a time when people in general want to keep very liquid. The issuing bank, on the other hand, would not wish to incur an obligation to maintain by redemption a value of its currency higher than that at which it had issued it. To maintain profitable investments, the bank would presumably be driven to buy 
interest-bearing securities and thereby put cash into the hands of people looking for other investments as well as bring down the long-term rates of interest, with a similar effect. An institution with a very large circulation of currency might even find it expedient to buy for storage quantities of commodities represented in the index that tended to fall particularly strongly in price." [Hayek (1976) 1990, p. 99] This means, Hayek allows that to avoid deflationary effects of limited money-supply, banks must increase money supply; that is, banks must increase money-supply. However, Hayek wants to abolish central bank because the central banks are prone to inflate money for fighting deflation.

It should be noted here that increase of gold as money is also a necessity. Because production of more goods will lead to increase demand of gold-money to facilitate the exchange of these more goods in the market, to keep intact the prices of other commodities. Rothbard himself accepts that otherwise, "the increased annual production of goods will more than offset the gradual increase in the money stock. The result will be a gradual fall in the price level, an increase in the purchasing power of the currency unit or gold ounce year after year". [Rothbard 2007, p. 20] This means that if volume or amount of gold money is not increased corresponding to the increase of productions, the purchasing power of the gold will increase and the purchasing power of commodities will continue to decrease year after year. In course of time small exchanges will become impossible as gold could not be divided in such units with which smaller exchanges in retail markets can be met. On the other hand, banks will be profited by increasing the value or price of their gold-reserve for readjusting the price of gold with the increase of production exchange of which will have to be adjusted with the unaltered quantity of gold-money. Therefore, to keep pace with the increased production, gold-money has to be increased accordingly.

Austrian economists themselves are aware of these limitations of gold-money. Hulsmann writes, "The qualification "virtually" takes account of the fact that there are certain technological limitations on the use of the precious metals. Suppose there are high growth rates over an extended period of time. In this case, it might be necessary to reduce coin sizes to such an extent that producing and using these coins becomes unpractical. This problem is very real in the case of gold. It has never existed in the case of silver- which is also why many informed writers consider silver to be the money par excellence. In any case, such technological problems pose no problem. As Bishop Oresme explained more than 700 years ago, the thing to do in such cases is simply to abandon the use of the unpractical coins, say gold coins, and switch to another precious metal, say silver. And, we may add, on the free market there are strong incentives to bring about such switching promptly and efficiently. No political intervention is necessary to support this process." [Hulsmann 2008, p. 61]

Rothbard, an eminent economist of Austrian School also accepts that "since the concept of the supply of money is vital both for the theory and for applied historical analysis of such consequences as inflation and business cycles, it becomes vitally important to try to settle these questions, and to demarcate the supply of money in the modern world." [Rothbard, Undated-1, p.144]

\subsection{Austrians economists accept that they cannot define money and that they are not sure whether their prescribed private banking system will ensure smooth economic activity or cause any harm to the economy}

\subsection{A. Austrian economists have even no vague idea about what money is}

Hayek does not know how the competing currencies will behave in future. He does not claim that he is giving the final and correct decision on what money should be and how best the money will be created and circulated in the economy. He writes, "I am of course very much aware that I have only scratched the surface of the complex of new questions and that I am still very far from having solved all the problems which the existence of multiple concurrent currencies would raise. Indeed, I shall have to ask a number of questions to which I do not know the answer; nor can I discuss all the theoretical problems which the 
explanation of the new situation raises. Much more work will yet have to be done on the subject." [Hayek (1976) 1990, p. 13]

Austrians economists are not practical; they only deals the issues relating to the freedom of printing money theoretically without having any practical touch. Hayek writes, "The questions this reform raises are at present much more theoretical than the practical proposal because the more far reaching suggestion is clearly not only much too strange and alien to the general public to be considered for present application. The problems it raises are evidently also still much too little understood even by the experts for anyone to make a confident prediction about the precise consequences of such a scheme." [Hayek (1976) 1990, p. 26]

At last, Hayek becomes hopeless in suggesting what exactly the Austrians want to mean by 'money'. He writes, "We do not even quite know what exact qualities we want because in the two thousand years in which we have used coins and other money, we have never been allowed to experiment with it, we have never been given a chance to find out what the best kind of money would be. [Hayek 2019 April, p.4]

\subsection{B. Austrian economists are not sure whether their prescribed private banking system will ensure smooth economic activity or cause any harm to the economy}

Hayek is confessed, "Nor can we find an answer to the question of what would happen if that monopoly [of the government and of the Central Bank] were abolished and the provision of money were thrown open to the competition of private concerns supplying different currencies." [Hayek (1976) 1990, p. 27]

"A more difficult question, the answer to which is perhaps not so clear, is how far the unavoidable appearance of what one may call parasitic currencies, i.e. the pyramiding of a superstructure of circulating credit through other banks carrying cheque accounts and perhaps even issuing notes in the denomination of the currency of the original issuer, would interfere with the issuer's control over the value of his own currency. So long as such parasitic issues were clearly labeled as debts to be paid in the currency of the issuer it is difficult to see how this could be or should be prevented by law." [Hayek (1976) 1990, p. 64]

"I do not see how the ordinary legal protection of brand names or trademarks could prevent the issue of such claims in the form of notes, and very much doubt whether it would be desirable to prevent it by law, especially in view of the essential similarity between such notes and deposits subject to cheque which .even the issuing banks would hardly wish to prevent." [Hayek (1976) 1990, p. 64]

"But what type of financial and banking institutions would market participants find most useful and desirable under a regime of money and banking freedom? The answer is that we don't know at this time precisely because government has monopolized the supplying of money; and it imposes, through various state and federal regulations, an institutional straitjacket that prevents the discovery of the actual and full array of preferences and possibilities that a free market in monetary institutions might be able to provide and develop over time." [Ebeling Aug 2012, p. 9]

"Until monetary and banking freedom is established, we have no way of knowing which of the two alternatives would be the most preferred. This is for the simple reason that under the present governmentmanaged and government-planned monetary and banking system, market competition is not allowed to demonstrate which options suppliers of financial intermediation might find it profitable to offer and which options users of money and financial institutions would decide are the ones best fitting their needs and preferences." [Ebeling Aug 2012, p. 9] 
Ebeling explains, "In the absence of government regulation and monopoly control, a free monetary and banking system would exist; it would not have to be created, designed, or supported. A market-based system would naturally emerge, take form, and develop out of the prior system of monetary central planning.

What would be its shape and structure over time? What innovations and variety of services would a network of free, private banks offer to the public over time? What set of market-determined commodities might be selected as the most convenient and useful media of exchange? What types of money substitutes would be supplied and demanded in a free-market world of commerce and finance? Would many or most banks operate on the basis of fractional or 100\% reserves? There are no definite answers to these questions, nor can there be. It is deceptive to believe, as Walter Lippmann explained, that we could comprehend and anticipate all the outcomes that will arise from all the market interactions and discovered opportunities that the complex processes of the free society would generate. It is why liberty is so important. It allows for the possibilities that can only emerge if freedom prevails. It's why monetary freedom, too, must be on the agenda for economic liberty in this new twenty-first century." [Ebeling Aug 2012, p. 13]

Austrian economists are confused whether money would be $100 \%$ commodity based or fiat money. Ebeling writes, "Suppose that monetary and banking freedom were established. What type of banking system would then come into existence? Some advocates of monetary freedom have insisted that a free banking system should be based on a 100 percent commodity money reserve. Others have argued that a free banking system would be based on a form of fractional-reserve banking, with the competitive nature of the banking structure serving as the check and balance on any excessive note issue by individual banks." [Ebeling Aug 2012, p. 9]

"Whether most banks would be closer to the 100 percent reserve end of this spectrum or farther from it is not - and cannot be - known until the monetary and banking system is set free from government regulation, planning, and control. As long as the government remains as the monetary monopolist, there is just no way to know all the possibilities that the market could or would generate. Indeed, for all we know, the market might devise and evolve a monetary and banking system different from that conceived even by the most imaginative free-banking advocates." [Ebeling Aug 2012, p. 10]

Hayek is confused whether people will accept governments' fiduciary currency in preference to $100 \%$ pure commodity currency. He wrote, "Where I am not sure is whether in such a competition for reliability any government-issued currency would prevail, or whether the predominant preference would not be in favour of some such units as ounces of gold." [Hayek (1976) 2009, p. 20].

\subsection{Austrian economists accepts that their prescribed private banking system and the multi- currency system will do harm to the economy}

Hayek accepts that there is a strong possibility that in a competitive market of issuing money banks would be lured to increase lending their money and would reduce interest rate and thus huge money will be dumped in the economy. He writes, "everybody indebted in the currencies for which a higher rate of interest has to be paid will try to borrow cheap in order to acquire currencies in which he can repay the more burdensome loans. And all the banks that have not reduced their lending rate will promptly return to the bank that lends more cheaply all of its currency they receive. The result must be the appearance on the currency exchange of an excess supply of the over issued currency, which will quickly bring about a fall in the rate at which it can be exchanged into the others. And it will be at this new rate that commodity prices normally quoted in other currencies will be translated into the offending currency; while as a result of its over-issue, prices normally quoted in it will immediately driven up. The fall in the market quotation and the rise of commodity prices in terms of the offending currency would soon induce habitual holders 
to shift to another currency. The consequent reduction in the demand for it would probably soon more than offset the temporary gain obtained by lending it more cheaply. If issuing bank nevertheless pursued cheap lending, a general flight from the currency would set in; and continued cheap lending would mean that larger and larger amounts would be dumped on the currency exchange." [Hayek (1976) 1990, pp. 6364]

"It remains true, however, that so long as good and bad currencies circulate side by side, the individual cannot wholly protect himself from the harmful effects of the bad currencies by using only the good ones in his own transactions. Since the relative prices of the different commodities must be the same in terms of the different concurrent currencies, the user of a stable currency cannot escape the effects of the distortion of the price structure by the inflation (or deflation) of a widely used competing currency." [Hayek (1976) 1990, p. 89]

In the private banking system, there will remain some commercial banks who will act as intermediary between savers (lenders to the bank) and borrowers. According to Austrian economists, these commercial banks will issue credit-moneys out of nothing and the credit-moneys will have to be redeemed or converted into the money issued by the money-issuing banks. They argue that the increase of creditmoneys will cause havoc to the financial and economic system. "Wicksell and later von Mises made it clear that this arrangement [credit-creation by commercial banks] must lead to violent recurring fluctuations of business activity-the so-called 'trade-cycle'.". [Hayek (1976) 1990, p. 92]

"In the system that Hayek provides, however, each bank-whether public or private, can issue its own fiat money, build its reputation and try to limit risky behavior in a framework of competition. Selgin and White, however, explain that such a system is inconvenient due to the multiplicity of units of measures, which gives rise to the temptation to embark on a concerted and unlimited expansion of the money supply." [Ravier No date]

The most dangerous of all is that there is every possibility of bank failure and people may even lose the whole value of his money. Hayek writes, in the event of "the complete collapse of one currency ... the holders of cash, either in the form of notes or of demand deposits in a particular currency, might lose their whole value." [Hayek (19761990), pp. 128-129]

Hayek is afraid that even the currency of a nation may be subdued by the enormous use of foreign currency by its people. He writes, "It is possible that in some very small countries with a good deal of international trade and tourism, the currency of one of the bigger countries might come to predominate." [Hayek (1976) 1990, p. 25]

Mises admits that if money-issuing private banks form a cartel for the sake of expanding their fiat money, then the economy and the banking (financial) system will be destroyed. He wrote, "[W] hat about a cartel of the commercial banks? Could not the banks collude for the sake of a boundless expansion of their issuance of fiduciary media? The objection is preposterous. As long as the public is not, by government interference, deprived of the right of withdrawing its deposits, no bank can risk its own good will by collusion with banks whose good will is not so high as its own. One must not forget that every bank issuing fiduciary media is in a rather precarious position. Its most valuable asset is its reputation. It must go bankrupt as soon as doubts arise concerning its perfect trustworthiness and solvency. It would be suicidal for a bank of good standing to link its name with that of other banks with (a) poorer good will. Under free banking a cartel of the banks would destroy the country's whole banking system. It would not serve the interests of any bank." [Mises 1949, p. 447]

Even under free banking system increase in credit expansion will lead to boom-bust cycle. "Hazlitt thus found in such credit expansion a cause of the business cycle, which he thought could occur even with 
"free banking," because banks would be pressured by competition constantly to lower their reserve ratios. [Blanchette, 2004, p 35]

Possibility of prevalence of concurrent currencies is also a utopia. If many currencies are in use in an area/ region and people has the right to refuse to accept any currency he does not trust, then there will be exchange problems. Besides, the very nature of money is that it should be universally accepted. If any money is not accepted by some persons of a given region, then the money loses its universality. Again, if currencies made of different commodities, then people will have an inclination to accept the more saleable commodity money and, thus, only most saleable commodity money will prevail and the use of other moneys will be discarded. Hayek himself writes that in the free market "there would be an inevitable tendency for the less marketable of the series of goods used as media of exchange to be one by one rejected until at last only a single commodity remained, which was universally employed as a medium of exchange; in a word, money" [Mises, 1953, pp. 32-33] Again, if everyone permitted to issue commodity-currency, then everybody will be lured to pass off the commodity that he can produce as money. It will lead to a barter system. That means a complete chaos in purchasing and selling.

"We argue that Hayek's proposal is Utopian, since only commodity money can emerge in the unhampered market. Moreover, we show that even - for the sake of the discussion-his idea would be realized, the competing fiat currencies could not be a solution to economic crises-quite the opposite, it could rather enhance the business cycles. We prove that Hayek does not fully understand the nature of money and its function. In particular, we criticize the concept of competition among freely fluctuating currencies, especially: fiat currencies-since, as long as people seek profits, the best situation occurs when in the market is only one money - and the idea of stabilizing the purchasing power of money, pointing out that it would be useless, or even destructive policy." [Sieron Undated, p.1] "We can see that the crises may occur under all possible monetary system, because whatever the money-fiat or commodity - will be used, as long as banks will be permitted to create it (or its substitutes) out of thin air, the business cycles will happen." [Sieron Undated, p.1]

"Indeed, the competition in the coinage - since all coin producers would be likely to debase their coins more and more to grasp extra profit (of course not in the free market, but only when there are few legal tenders, which allows spoiling money) — would lead to hyperinflation." [Sieron Undated, p.3] Hülsmann writes that "There is also a fourth implication of granting legal tender privileges for debased coins, especially if these privileges, as we have so far assumed, are granted indiscriminately. This implication is that coins can no longer be produced on a competitive basis without destroying the currency. When a coin producer can debase his product indefinitely and heap it on the other market participants, the race to the bottom has no stopping point short of the resolute rejection of any further monetary exchange by the citizens, that is, short of the total disintegration of the market. This is why legal tender privileges have never been granted under such conditions." [Hulsmann 2004, p. 47]

Douglas Jay, PC, MP comments on the chaotic economy that would result if the monetary system is arranged according to what Hayek is arguing for. He writes, "He [Hayek] wants governments to refrain from declaring anything legal tender, and all individuals to use what money they like. He says that people should be 'free to refuse any money they distrusted and to prefer money in which they had confidence'. But suppose I offer one paper rouble in payment of a bus fare, and the conductor refuses to accept it; what happens? Is the bus stopped while the conductor and I seek a ruling which nobody can give? And imagine the controversies in the bus over the latest exchange rate between one currency and any other. Professor Hayek's new scheme would produce chaos and slow down the whole business of production and exchange in a welter of disputation. That is why history has forced governments to legislate on legal tender. Professor Hayek might nearly as well ask for the abolition of all courts and indeed governments, and let every individual prosecute his own disputes. Such an argument has, no doubt a superficial appeal. But human history argues rather strongly against it. ... But in thinking you can take control of the 
currency out of the hands of modern elected governments, and put it in the hands of some mysterious wise men meditating in some ivory tower, Professor Hayek is flying in the face of reality. The public simply will not allow control of money to be put beyond their control any more than control of laws or taxes." [Hayek (1976) 2009, pp. 27-28]

Even experienced bankers are afraid of trying private banking system for experiment. Hayek expresses his wishes thus: "I am also convinced that if a new generation of young bankers were given the opportunity they would rapidly develop techniques to make the new forms of banking not only safe and profitable but also much more beneficial to the whole community than the existing one." [Hayek (1976) 1990, p. 93] However, he is not sure. He writes, "I am saying this from the experience of many discussions, no senior banker, who understands only the present banking system, can really conceive how such a new system [money-issuing private banking system] would work, and he would not dare to risk and experiment with it. I think we will have to count on a few younger and more flexible brains to begin and show that such a thing can be done." [Hayek 2019 April, p.5]

Form the above narration, it emerges that creation and circulation of concurrent currencies by private banks in the free banking system is unrealistic, chaotic, and a utopia; it can never be achieved; and if tried, will lead economy to a complete disaster.

\section{11. Austrian School's explanation that only credit expansion to businesses (Mb) leads to over- investment and ultimate recession while other types of credit expansion do not lead to over- investment and ultimate recession is wrong}

\section{The Austrian theory of Ma (aggregate money supply)}

Rothbard argues, "while the supply of money $(M a)$ is the vitally important supply side of the "money relation" (the supply of and demand for money) that determines the array of prices, and is therefore the relevant concept for analyzing price inflation, different parts of the money supply play very different roles in affecting the business cycle." [Rothbard 1978, p. 154] "Mises distinguished between "simple inflation," in which the banks create more deposits through purchase of government bonds and genuine "credit expansion," which enters the business loan market and generates the business cycle." [Rothbard 1978, p. 154] Rothbard also views that "Inflationary bank credit that enters the market through financing government deficits does not generate the business cycle; for, instead of causing overinvestment in higher-order capital goods, it simply reallocates resources from the private to the public sector, and also tends to drive up prices." [Rothbard 1978, p. 154] "Indeed, the reason why bank financing of government deficits may be called simple rather than cyclical inflation is because government demands are "consumption" uses as decided by the preferences of the ruling government officials." [Rothbard 1978, p. 155] "The treasury borrows from the bank, and the bank provides the funds needed by issuing additional banknotes or crediting the government on a deposit account. Legally the bank becomes the treasury's creditor. In fact the whole transaction amounts to fiat money inflation. The additional fiduciary media enter the market by way of the treasury as payment for various items of government expenditure." [Ludwig von Mises, Human Action, $3^{\text {rd }}$ rev. ed. (Chicago: Henry Regency, 1966), p.570] [Quoted in [Rothbard 1978, p.154] The "phenomenon of large-scale bank loans to consumers ... too cannot be said to generate a business cycle. Inflationary bank loans to consumers will artificially deflect social resources to consumption rather than investment, as compared to the unhampered desires and preferences of the consumers. But they will not generate a boom-bust cycle, because they will not result in "over" investment, which must be liquidated in a recession." [Rothbard 1978, p. 155]

"Austrian theory of the trade cycle reveals that only the inflationary bank credit expansion that enters the market through new business loans (or through purchase of business bonds) generates the over- 
investment in higher-order capital goods that leads to the boom-bust cycle." [Rothbard 1978, p. 154] "the overinvestment-business cycle effects only resulting from inflationary bank loans to business." [Rothbard 1978, p. 155]" As Mises writes: "In dealing with the [business cycle] we assumed that the total amount of additional fiduciary media enters the market system via the loan market as advances to business." [Ludwig von Mises, Human Action, $3^{\text {rd }}$ rev.ed. (Chicago: Henry Regency, 1966), p.570] [Quoted in Rothbard 1978, p.155]

"In addition to $M a$, then, Austrian economists should be interested in how much of a new supply of bank money enters the market through new loans to business. We might call the portion of new Ma that is created in the course of business lending, $M b$ (standing- for either business loans or business cycle). If, for example, a bank creates $\$ 1$ million of deposits in a given time period, and $\$ 400,000$ goes into consumer loans and government bonds, while, $\$ 600,000$ goes into business loans and investments, then $M b$ will have increased by $\$ 600,000$ in that period" [Rothbard 1978, p.155] However, "it is impossible to determine how much of an increase in deposits (increase in $M a$ ) went to finance business loans and investments, and how much went into reserves or consumer loans. In trying to determine increases in $M b$ for any given period, then, it is impossible to be scientifically precise ... In practice, since bank capital is relatively small, as are bank investments in corporate bonds, the figure for commercial bank loans to business can provide a rough estimate of movements in $\mathrm{M} b$. With the development of the concepts of $\mathrm{M} a$ (total supply of money) and $M b$ (total new money supply going into business credit), we have attempted to give more precision to the Austrian theory of money, and to the theoretical as well as historical Austrian analysis of monetary and business cycle phenomena." [Rothbard 1978, p.156]

\section{Assessment of the Austrian school's theory of 'Ma'}

However, the explanation of Austrian economists that "inflationary bank loans to business" (Mb) leads to "the overinvestment-business cycle effects" and that there is really a difference between $\mathrm{Ma}$ and $\mathrm{Mb}$ in their effects on boom-bust cycle is wrong.

Money enters into the economy as loans from the central bank through the commercial banks. All the governments, individual consumers and businesses get loan from the commercial banks and all of them are bound to repay the principal amount of loan along with the interest accrued on the loan. The fact is that the aggregate amount of all these loans have to repaid with more amount of money i.e. aggregate amount of loans plus interest accrued on loans. But though the amount of principal money repayable to the commercial banks are there in the economy, yet the amount of money payable as interest is not there in the economy as the commercial banks have not injected that amount of money. Therefore, anybody or many among the borrowers (government, individual consumers, and businesses) must fail to repay the loan and thus may default. Therefore, not only the businesses but also the individuals and even the government may fail. In that case those who fail are likely to cause recession. Only business failure does not cause recession. Recession is caused mainly when one or some large banks fail or go NPA because most of their customers (government, individual consumers, and businesses) fail to repay their debt and banks become insolvent to meet withdrawal demands of their customers and unable to extend any further loans to their borrowers. Therefore, both the loans (Ma minus $\mathrm{Mb}$ ) (that cause 'simple inflation' according to the Austrian economists) and loans (Mb) (that cause 'cyclical inflation') should be blamed for recession if we hold any loan responsible for 'cyclical inflation' or for 'business cycle' or 'recession'.

However, the fact is that just increase of money supply (through either Ma minus $\mathrm{Mb}$ or $\mathrm{Mb}$ ) is not responsible for any inflation or for any recession or business cycle. Money must enter the economy and must be increased to facilitate increase in production and in employment. However, the only known method or process of money's appearance in the economy is lending money by the central bank to the economy through commercial banks as the central bank is the only issuer of money. This very process of lending money (that has to be repaid) to the economy is the crux of almost all the problems like liquidity 
crunch (shortfall of money in the economy for repayment of loan and for transaction of commodities), failure of businesses to repay the loan, credit crunch (banks failure to provide credit), bank's going NPA and failure to repay its borrowing from its customers and finally a breakdown in economic.

All these financial failures lead to depression or recession. Not just Mb but also whole amount of Ma is responsible for the cyclical booms and busts.

\section{12. Some observations on Austrian school's understanding of commodity money and fiat money}

\subsection{A. Austrian economists believe that increase in commodity money is less deflationary}

Mises argues that while inflation is disruptive to the economic growth, deflation is conducive to economic growth. "But whatever the reality and extent of diversion of resources into gold mining during deflation, it is clear that by 1949 Mises did not consider deflation a likely problem. Inflation, once government has monopolized the production of money, is the real danger. As long as there is a significant inflationary impulse (always strengthened by government intervention into money and credit), the cost of producing gold is its main advantage as a money since this is what restrains the inflationary impulse." [Herbener, p.79]

Why Mises preferred the deflationary effect of pure gold standard than the inflationary effect of expansionary fiat/fiduciary money system."The manner in which a supplier of gold coin, whether private enterprise or a government agency, is restrained from inflating the money stock under a gold standard is the market's imposition of gold's production costs on the profitability of its production." [Herbener 2002, p.77]

Buzzeo argues, “... deflation is good for an inflationary economy if all prices are allowed to drop in tandem. If profits remain the same in relation to the goods and services that I need to buy, I am not concerned with the final price that I sell a unit of housing for. I am only concerned with lower profits in relation to higher prices that I must pay for the things that I need." [Fred Buzzeo 27 Dec. 2010]

Supply (i.e. lending by the money-issuer) of money (commodity or fiat) must match the demand for loan, otherwise, economic activities will be sluggish. The supply of commodity-money will not be able to keep pace with the increasing demand for loan, as supply of commodity of which the money is made will be increasingly scarce. This inability to meet the demand of loan will hamper the growth or acceleration of the economy and prices of money will increase in relation to the price of commodities causing deflation. In that case, money-makers will get extra profit due to increased price of money. The increasing price of commodity-money will increase the price of that commodity (of which the money is made) also and those who deals in that commodity for business purpose (other than money creation) will also get extra profit. Thus, buyers will be bound to pay more for buying those commodities and money made of those commodities. This will cause increasing deflationary (decrease in CPI) effect on the economy causing severe destabilization in the market.

However, Hayek argues that deflation also causes instability in the economy. Hayek writes, "it [is] very doubtful whether gold was for the purpose of money really a good standard. It would turn out to be a very good investment, for the reason that because of the increased demand for gold the value of gold would go up; but that very fact would make it very unsuitable as money. You do not want to incur debts in terms of a unit which constantly goes up in value as it would in this case" [Hayek 1979, p. 4] Selgin also argues that "Under a gold standard, deflation becomes equivalent to a rising relative price of gold, which in turn means a greater diversion of resources to gold mining." [Selgin 1999, p. 261] 
Hayek wrote, during deflation, "People will be quite as reluctant to borrow or incur debts in a currency expected to appreciate as they will hesitate to lend in a currency expected to depreciate." [Hayek (1976) 2009 , p. 20] Hayek cites an example of deflationary effects of gold standard. He writes, "The early Middle Ages may have been a period of deflation that contributed to the economic decline of the whole of Europe." [Hayek (1976) 1990, p. 34]

\subsection{B. Austrian economists think that the increase in commodity money will not increase the supply of money}

Austrians argue that if money remains tied to any commodity then inflation (increase in money-supply) would not occur. According to them, commodity-money is made of commodity that already exists in the economy; therefore, more and more use of the commodity as money does not lead to any increase in its supply. Only the creation of circulation money (fiat money or credit money), that is not tied to any commodity or created out of nothing, adds extra money to the already supplied commodity-money. However, they are wrong in two ways. Commodity and commodity-money is not the same thing. Commodity-money is sub-set of commodity. When more and more commodity is used as money, it certainly increases the supply of money. Besides, the supply of commodity-money cannot not be treated as equal to supply of that commodity of which the money is made, because when commodity is used as money it loses its commodity-ness (as it is not consumed); it only acts as the medium or lubricator of exchange. As soon as it is used for consumption it loses its money-ness (because it can no more be used as money). While a part of the commodity is used as money, another part of the same commodity is marketed for sale. Commodity-money does not enter the economy through purchases like the non-money commodity that enters the economic activity through purchase or sale. As marketing of more and more commodities for sale increases the supply of commodity, so also increase in lending or borrowing commodity-money to the economy leads to increase in money-supply. However, lending the money that is already in circulation does not increase money-supply; purchasing or selling of money that already exist in the circulation also does not increase money-supply.

Austrian School's demand that if it is gold standard then money supply would not increase is wrong. Hayek himself writes that excessive gold production may lead to inflationary effects on the economy causing devaluation of money or increase in commodity-prices. He gives a example, "When in the 'fifties of the nineteenth century gold production increased considerably in California and Australia, people attacked the gold standard as inflationary. In those days Michel Chevalier, in his book Probable Depreciation of Gold, recommended the abandonment of the gold standard, and Béranger dealt with the same subject in one of his poems." [Mises 1953, p. 416]

The basic finding of Austrian economics is that 'circulation money' (fiat money and credit money created out of nothing) is the principal cause of both types of inflation (increase in the moneysupply and in the CPI). However, neither the circulation money nor the commodity money increases the CPI. Money, whether it is commodity-money or fiat money, does not make any difference after when it enters the economy. Money enters the circulation in the economy only as loan from the money issuer. Money issuer lends only to the borrowers who place their demand for loan. Those who borrow money do not purchase commodities above the market price. Therefore, increase in money supply does not tend to increase in prices. Austrian economists argue that government spending increases the supply of money and increase in money-supply increases the price of commodities. This is also wrong. Government gets money either through tax or as loan from the economy where money is already in circulation. This means 
government takes money from existing aggregate amount of money already supplied. The government then spends the money in the economy through purchases. Therefore, government spends what it takes from the economy. Therefore, government does not increase the supply of money. Spending by government also does not increase the prices of the commodities, because government buys commodities and services at the market price and not at above the market-price. Therefore, government spending cannot cause increase in commodity-prices. Commodity-prices increase because of other facts like payments of interest and tax that the producers add to the cost-price of their products.

\subsection{Fiat money created by the Central Bank is beneficial to the economy}

The economy is benefited by the creation of fiat money by the central bank at least in two ways.

First, fiat money creation frees labour and commodity from the commodity-money making processes for their other uses. The fiat-money creators will get the full benefit, of creating the money out of nothing, to the extent of the face-value of money and the interest from lending that money. However, in case of commodity-money, the issuer does not get any benefit from money creation. He only gets the interest on lending hs commodity-money. The only difference is in the case of commoditymoney-creation, both men and commodity are invested and in case of fiat money no such investment is needed. However, if it were fiat-money (and not commodity-money) then the men and commodity (that are used for creation of commodity-money) would be saved; and both the labor and the commodity could be used for production of commodities for purpose like public or private consumptions. A considerable labor-force will be wasted only to produce commodity-money and "they perform no genuine social function". [Rothbard 2007, p.19]

Second, the central bank shares the profit from creation of fist money with the government. Central bank, whether it is a private bank like the Federal Reserve Bank or a Nationalized Bank, is by law is bound to give the government a portion of its profit it earns from their banking services and moneycreation. Thus, the monopoly of money-creation is given to the central banks so that the profit from money-creation and interest earned through banking (lending) cannot be enjoyed by the private individuals but by the nation as whole. The share of profit that the government gets from the central bank is used for the public purpose that the people of the whole nation enjoys or uses.

Therefore, fiat-money system is more beneficial or less harmful to the economy than the commodity money is.

\subsection{As commodity money cannot be increased with the increasing demand for borrowing, so the demand for money should be met by increasing supply of fiat money}

If money remains tied to any (or many) commodity(s), money-creation cannot be increased beyond the limits of its availability in the nature (mines) and supply of money cannot be increased corresponding to the increasing demand for money in the economy. This will hamper the expansionary growth of the economic activities. Creation and supply (lending) can only be increased according to the demand for money (for borrowing) by the market, if money is created out of nothing as fiat-money. Therefore, fiat money system is less harmful (or more beneficial) to the economy than the commodity-money system. For these reasons returning to commodity-money system abolishing the fist-money system (as the Austrians recommend it to be) will not be judicious. 
Borrowers cannot distinguish between the commodity certificate and the fiduciary media. Mises wrote, "As a rule, it is not possible to ascertain whether a concrete specimen of money-substitute is a moneycertificate or a fiduciary medium." [Mises1998, p. 430] Therefore, it is impossible to ascertain whether the money issuing bank issues any fiduciary media or not. Therefore, it is also not possible to know whether the money that is lent is 'normal credit' or 'circulation credit'. Money has to be lent to meet the increasing demand for money. Stopping or reduction in lending will hamper the economic growth. Therefore, if lending of money increase inflation, then it a systemic defect of the economy. Restricting or reducing money lending cannot solve the problem of inflation or recession; it will only retard the economic activity.

\section{13. Austrian School's understanding of inflation (increase in money supply) and of inflation (increase in Consumer Price Index) is wrong}

\subsection{A. Inflation: Increase in money-supply}

Austrian School argues that government's monopoly of printing money solely responsible for increase in money supply and inflation. Hayek writes, "I do not think it an exaggeration to say that history is largely a history of inflation, and usually of inflations engineered by governments and for the gain of governments." [Hayek (1976) 1990, p. 34] "Since the task of preventing inflation has always seemed to me to be of the greatest importance, not only because of the harm and suffering major inflations cause, but also because I have long been convinced that even mild inflations ultimately produce the recurring depressions and unemployment which have been a justified grievance against the free enterprise system and must be prevented if a free society is to survive." [Hayek (1976) 1990, p. 13]

\section{Austrian School argue that "Inflation is the fiscal complement of statism and arbitrary government"}

Mises writes, "It is not just an accident that in our age inflation has become the accepted method of monetary management. Inflation is the fiscal complement of statism and arbitrary government. It is a cog in the complex of policies and institutions which gradually lead toward totalitarianism." [Mises 1953, p. 428] Hazlitt argues, "Inflation is an increase in the quantity of money and credit. Its chief consequence is soaring prices. Therefore, inflation - if we misuse the term to mean the rising prices themselves - is caused solely by printing more money. For this the government's monetary policies are entirely responsible." [Hazlitt Sept 1978] "The causes of inflation are not, as so often said, "multiple and complex", but simply the result of printing too much money." [Hazlitt Sept 1978]

\subsection{B. Inflation: Increase in commodity-prices}

Mises argues, "The main point is that every increase in the quantity of money in circulation brings about a tendency of prices and wages to rise." [Mises 1953, p. 425]

\subsection{Creation of credit-money causes increase in money-supply, price-rise, and recession}

Rothbard writes, "Deposits are not in fact all redeemable in cash in a system of fractional reserve banking; but so long as individuals on the market think that they are so redeemable, they continue to function as part of the money supply. Indeed, it [deposit created by banks] is precisely the expansion of bank demand deposits beyond their reserves that accounts for the phenomena of inflation and business cycles." [Rothbard 1978, p. 146] He argues, "We have so far emphasized that bank credit expansion under fractional-reserve banking (or "creation of counterfeit warehouse receipts") creates price inflation, loss of purchasing power of the currency unit, and redistribution of wealth and income. Euphoria caused 
by a pouring of new money into the economy is followed by grumbling as price inflation sets in, and some people benefit while others lose." [Rothbard 2007, p.54]

\section{Assessment of Austrian School's understanding of inflation (increase in money supply) and of inflation (increase in Consumer Price Index)}

The Austrian School's argument that government is the sole responsible for increase in money-supply and inflation is wrong. Hayek himself has given example that inflation and deflation have been caused in the past where government had no role to play. He wrote, “... the gold and silver discoveries in the 16th century had a similar [inflationary] effect. [Hayek (1976) 1990, p. 34] "The early Middle Ages may have been a period of deflation that contributed to the economic decline of the whole of Europe." [Hayek (1976) 1990, p. 34]

Mises mixes the "inflation" (price-rise) with the "inflation" (expansion of both commodity money metal fiat/ fiduciary money) when he argues that there is "the political impetus to inflate with a managed fiat-money System". [Herbener, 2002, p. 75] What Mises really want to mean by "inflation" is not clear. Once he used the term "inflation" to mean "credit expansion" when he writes, "it [the gold standard] checks large-scale inflationary ventures on the part of governments" and that the "inflationists" destroyed the gold standard "because they were committed to the fallacies that credit expansion is an appropriate means of lowering the rate of interest and of 'improving' the balance of trade". [Mises 1998, pp. 471-72] But increase in money-supply and price-increase are not the same thing.

\section{The real causes of inflation}

The fact is that inflation does not occur when money is used for only purchasing or selling purposes, because the buyer do not increase buying prices just being willing to pay more than the market (selling) prices. Exchanges occur between two commodities (one is pure commodity and the other is commoditymoney) of equal sale-prices. The selling price increases above the cost prices principally because the seller adds the interest she has to pay to her financier and the tax she has to pay to the government. Therefore, it is not increase in supply of money, but the payment of the interest and the tax that the entrepreneur has to make are the primary causes of the increase of selling price. You cannot avoid both of these (interest and tax) payments. Therefore, you cannot avoid increasing of commodity-prices whether the money you use is commodity-money or is fiat money. Therefore, the Austrian's claim that if it were commodity money there will be no increase in prices is wrong because all money initially enters the economy as loan from the banks and has to be repaid with accrued interest. Payment of tax also cannot be avoided. The fact is that there is no way to avoid or escape increasing inflation. The pace of increase in inflation can be reduced if interest rate and the tax is reduced; but then after certain limit both of these cannot be reduced and then you have to bear whatever increase in inflation occurs.

Increase in money supply automatically does not increase prices. It occurs when people or entrepreneur borrows money from the banks. The borrowers do not pay more than the market price when they buy any commodity and, therefore, do not cause any increase in prices of commodities. Prices of commodities increases only when demand of commodities (or services) become more than its supply; prices cannot increase if commodity (or services) is abundant in supply for sale. Therefore, Austrian's argument is wrong that increase in money-supply always lead to increase in prices of commodities and services. 


\section{14. The Austrian School's explanation of why and how recession sets in and how recession can be eliminated or abated is wrong}

\subsection{A. Austrian School's Diagnosis of the causes of recession}

Economists of the Austrian School view that money creation through fractional reserve banking is the sole cause of boom-bust cycle.

"At first, bankers limited the printing of bank notes to the value of metals on deposit, but they soon realized that the commodity money held would only rarely be redeemed by customers. Hence it became practicable to print money in excess of deposits on hand in which case it was backed only to the extent of some fraction of the deposits held at a given time. Fiduciary media supported by fractional reserves are thus only partially backed by reserves of valuable commodities on deposit. [Ravier No date, p. 3]

Rothbard argues, "In the case of bank money [created out of fractional reserve banking] ... the effect of the banker's depredations will not only be price inflation and redistribution of money and income, but also ruinous cycles of boom and bust generated by expansions and contractions of the counterfeit bank credit." [Rothbard 2007, p. 40] He writes, "We have so far emphasized that bank credit expansion under fractional-reserve banking (or "creation of counterfeit warehouse receipts") creates price inflation, loss of purchasing power of the currency unit, and redistribution of wealth and income. Euphoria caused by a pouring of new money into the economy is followed by grumbling as price inflation sets in, and some people benefit while others lose. But inflationary booms are not the only consequence of fractionalreserve counterfeiting." [Rothbard 2007, pp. 54-55]

"Hazlitt also believed that with the appearance of banks, economic booms and busts were born. ... It is from this system, however, that fractional reserve banking evolved, Hazlitt writes. And from this came the devastating economic fluctuations known as the business cycle. Bankers soon began to realize that the amount of gold demanded in its physical form was far less than the amount of gold held in reserve. For the entrepreneurial banker here was a profit opportunity. If loans were made from the present gold stock and this gold stock was rarely touched, why not increase the amount of outstanding credit beyond the bank's reserve capability? ... Thus according to Hazlitt, banks continued to lend funds above the amount of gold held in their vaults. It is here that the "boom" begins." [Blanchette, 2004, p. 35].

\section{Austrian school believes that mal-investment is the result of reduction of interest rate by the government; free market interest is better for economy}

"According to the Austrian Business Cycle Theory, the boom-bust cycle is not a market phenomenon (it is especially a Rothbard's notion), but it is caused by the government intervention in the free market. Indeed, a privilege given to the bankers allows them to lend its customers " money which was only deposited in the bank, not lent it. This "violation of the traditional rule of conduct" [Huerta de Soto, 2009] leads to the credit expansion, which artificially lowers the interest rate, and causes the boom, which has to result in the bust, since the pool of real savings did not before increase accordingly to expanded banking credit." [Sieron Undated, p.1]

Hayek argues, "It [increase in fiduciary media] will in addition have caused misdirection of production [mal-investment] and drawn labour and other resources into activities which could be maintained only if the additional investment financed by the increase in the quantity of money could be maintained." [Hayek (1976) 1990, p. 97] 


\section{According to "The Circulation-Credit Theory of Business Cycles" of the Austrian School, only the portion of the "Circulation Credit" that is lent to the businesses cause mal-investment or over- investment.}

"Mises made a distinction between credit that is backed by savings, and credit that does not have any backing. The first type of credit he labeled commodity credit. The second, he labeled circulation credit." [Shostak $2018 \mathrm{Jan}$ ] "It is circulation credit that plays the key role in setting the boom-bust cycle process." [Shostak 2018 Jan]

"When credit is fully backed by savings - that is, it is commodity credit — it permits the expansion of tools and machinery. With better infrastructure, it is now possible to produce not only more goods but goods of a better quality. The expansion of real wealth is now possible." [Shostak 2018 Jan] "In an unhampered market economy, borrowers are users of savings who make sure that savings are employed in the most efficient way - generating profits. This means that real savings are employed in accordance with consumers' most important priorities. We can thus see here that as long as banks facilitate commodity credit, they should be regarded as the agents of wealth generation." [Shostak 2018 Jan]

"This is, however, not the case with respect to the circulation credit. No goods were produced and saved here. Once the borrower uses the unbacked claims, it is at the expense of the holders of fully backed claims. In this way, circulation credit undermines the true wealth generators." [Shostak 2018 Jan] "In contrast, whenever banks embark on the lending of circulation credit, they in fact become the agents of real wealth destruction." [Shostak 2018 Jan] "As opposed to commodity credit, circulation credit is not supported by any real saving. This type of credit is just an empty claim created by banks. In the case of commodity credit, the borrower secures goods that were produced and saved for him." [Shostak 2018 Jan]

"Now, as a result of an increase in the supply of circulation credit, money market interest rates fall below the natural rate, that is, the rate that would be established in a free market." [Shostak 2018 Jan] "As a result of the artificial lowering of interest rates, businesses undertake various new capital projects to expand and lengthen the production structure. Prior to the lowering of interest rates, these capital projects didn't appear to be profitable. Now, however, as money market rates are kept below the natural rate, economic activity zooms ahead and an economic boom emerges." [Shostak 2018 Jan] "These illusory plans, suggested by the falsification of business calculation as brought about by the cheap money policy, can be pushed forward only if new credits can be obtained at gross market rates which are artificially lowered below the height they would reach at an unhampered loan market. It is this margin that gives them the deceptive appearance of profitability." [Mises 2018 Sept, p.3]

The Austrian economists argue that the presence of /increase in fiduciary media leads to mal-investment or over-investment that is not supported by any growth of real wealth. Businessmen are lured by the availability of borrowing fiduciary media at a very low interest to invest in production of various commodities. But, as no real wealth is created against the fiduciary media, so there will be no such commodity with which those products (created using fiduciary media) can be exchanged. Therefore, those products will not be sold. This will cause boom phase in production. Such investments are malinvestments.

"The forced lowering of interest rates bring into being production processes that would not otherwise be undertaken. A production structure is now created that produces goods and services that consumers in fact cannot afford." [Shostak 2018 Jan] "Instead of using the limited pool of the means of sustenance to make tools and machinery that will generate consumer goods on the highest individual priority list, the means of sustenance are wasted on capital goods that are geared towards the production of low-priority consumer goods." [Shostak 2018 Jan] 
"At some point, the producers of such goods will discover that they cannot make a profit or even complete their plans. What we have here is not over-investment but misdirected investment or malinvestment." [Shostak 2018 Jan] "The expansion of the production structure takes time and the limited subsistence fund may not be sufficient to support the expansion of the capital structure. If the new flow of the production of consumer goods does not emerge quickly enough to replace the currently consumed consumer goods, the subsistence fund comes under pressure." [Shostak 2018 Jan] "At some point in time, banks discover that marginal businesses are starting to under-perform. This causes them to slow-down the expansion of circulation credit, which in turn puts an upward pressure on interest rates. As a result this starts to undermine various other business activities (non-marginal), and can often be the precipitating event that leads to an economic bust." [Shostak 2018 Jan]

"The breakdown appears as soon as the banks become frightened by the accelerated pace of the boom and begin to abstain from further expansion of credit. The boom could continue only as long as the banks were ready to grant freely all those credits which business needed for the execution of its excessive projects, utterly disagreeing with the real state of the supply of factors of production and the valuations of the consumers." [Mises 2018 Sept, p.3] However, "The change in the banks' conduct does not create the crisis. It merely makes visible the havoc spread by the faults which business has committed in the boom period." [Mises 2018 Sept, p.2]

"For at some point in the process, a reaction sets in. An actual bank run might set in, sweeping across the banking system; or banks, in fear of such a run, might suddenly contract their credit, call in and not renew their loans, and sell securities they own, in order to stay solvent. This sudden contraction will also swiftly contract the amount of warehouse receipts, or money, in circulation. In short, as the fractional-reserve system is either found out or in danger of being found out, swift credit contraction leads to a financial and business crisis and recession. There is no space here to go into a full analysis of business cycles, but it is clear that the credit-creation process by the banks habitually generates destructive boom-bust cycles." [Rothbard 2007, pp. 54-55]

"the whole crazy structure we have as a result, this monopoly originally only of issuing gold money, is very largely the cause of the great fluctuations in credit, of the great fluctuations in economic activity, and ultimately of the recurring depressions." [Hayek 1979, pp.313-314]

Frank Shostak explains this phenomenon in his "Can Government Stimulus Bring Us Out of Recessions?" thus: “... we suggest that as a rule a recession emerges in response to a decline in the growth rate of money supply. Usually this takes place in response to a tighter stance of the central bank. Various activities that sprang up on the back of the previous strong money growth rate (usually because of previous loose central bank monetary policy) come under pressure.

These activities cannot support themselves - they survive because of the support that the increase in money supply provides. The increase in money diverts to them real wealth from wealth generating activities. Consequently, this weakens these activities, (i.e. wealth-generating activities).

As a result of the tighter stance and a consequent fall in the growth rate of money, this undermines various nonproductive activities and this is what recession is all about.

Given that, nonproductive activities cannot support themselves since they are not profitable, once the growth rate of money supply declines, these activities begin to deteriorate. (A fall in the money growth rate means that the nonproductive activities access to various resources is curtailed). 
Recession then is not about a weakening in economic activity as such but about the liquidations of various nonproductive activities that sprang up on the back of increases in money supply." [Shostak April 2019, Italics added]

"In this framework of thinking, which is based on the ideas of Ludwig von Mises, fluctuations in the growth rate of money supply always set in motion the phenomenon of boom-bust cycle regardless of statistical correlation between the money supply growth rate and economic activity." [Shostak April 2019]

\subsection{B. Austrian school argues what the money-issuing authority should do once boom or recession sets in}

"As soon as the afflux of additional fiduciary media comes to an end, the airy castle of the boom collapses. The entrepreneurs must restrict their activities because they lack the funds for their continuation on the exaggerated scale. Prices drop suddenly because these distressed firms try to obtain cash by throwing inventories on the market dirt cheap. Factories are closed, the continuation of construction projects in progress is halted, workers are discharged. As on the one hand many firms badly need money in order to avoid bankruptcy, and on the other hand no firm any longer enjoys confidence, the entrepreneurial component in the gross market rate of interest jumps to an excessive height." [Mises Sept. 2018, p.3]

"It must realize that the depression is in fact the process of readjustment, of putting production activities anew in agreement with the given state of the market data: the available supply of factors of production, the valuations of the consumers, and particularly also the state of originary interest as manifested in the public's valuations." [Mises Sept. 2018, p.4]

"A good many things have changed. Forced saving and, to an even greater extent, regular voluntary saving may have provided new capital goods which were not totally squandered through malinvestment and overconsumption as induced by the boom. Changes in the wealth and income of various individuals and groups of individuals have been brought about by the unevenness inherent in every inflationary movement." [Mises Sept. 2018, p.4]

"Obviously then, both aggressive fiscal and monetary policies, which will provide support to nonproductive activities, will re-start the weakening process of real wealth generation thereby weakening the prospects for a meaningful economic recovery. Hence, once an economy falls into a recession the government and the central bank should restrain themselves and do nothing." [Shostak April 2019]

Shostak writes, "During an economic crisis, what is required is for the government and the central bank to do as little as possible. With less tampering, more real wealth remains with wealth generators, which allows them to facilitate a further expansion in the pool of real wealth.

With a larger pool of wealth, it will be much easier to absorb various unemployed resources and eliminate the crisis. Aggressive monetary and fiscal policies will only hurt the process of wealth generation thereby making things much worse.

As long as the pool of real wealth is still growing, the government and the central bank could get away with the illusion that they can grow the economy. However, once the pool begins to stagnate or decline, the illusion of successful government and central bank policies is shattered." [Shostak April 2019 April, Italics added] 
"It is not surprising that Mises was strongly opposed to the idea that central banks should impose "low" interest rates during a recession in order to keep the economy going. Instead, he believed that the policy makers should not engage in the artificial lowering of interest rates but rather refrain from any attempts to manage the economy via monetary policy. By curtailing its interference with businesses, the central bank provides breathing space to wealth generators and thereby lays the foundation for a durable economic recovery.” [Shostak Jan. 2018]

Hayek suggests boom-bust cycle occur only if the government (or the central bank) issues fiduciary money (fiat money) and does not occur if private banks issue fiduciary media. He writes, "... recurrent periods of depression and unemployment, is a consequence of the age-old government monopoly of the issue of [fiduciary] money. I have now no doubt whatever that private enterprise, if it had not been prevented by government, could and would long ago have provided the public with a choice of currencies, and those that prevailed in the competition would have been essentially stable in value and would have prevented both excessive stimulation of investment and the consequent periods of contraction." [Hayek (1976) 1990, p. 14]

\section{Assessment of the theory of Boom-Bust Cycle}

The assertion of the Austrian economists that "with respect to the circulation credit. No goods were produced and saved here. Once the borrower uses the unbacked claims, it is at the expence of the holders of fully backed claims. In this way, circulation credit undermines the true wealth generators" [Shostak Jan. 2018] is wrong. The holders of the money (borrowers from the bank) do not have any claim on the bank; on the other hand they are liable to repay the money they have borrowed with accrued interest. Whether the money they borrowed is fully backed or unbacked does not matter to them. They do not and cannot know whether the money they have borrowed is backed or unbacked; in both cases, they produce wealth by using their borrowed money in production. The only difference between the fully backed mondey and the unbacked money is that the banker who lends fully backed money get less profit than the banker who lends unbacked money. Therefore, it is not true that "circulation credit undermines the true wealth generators".

Therefore, it is also not true that the "ruinous cycles of boom and bust [is] generated by expansions and contractions of the counterfeit bank credit". [Rothbard 2007, p. 40] On the contrary, if money would be backed by any commodity, then a huge number of labour and commodity would be wasted only to create money that serves no purpose of creating or consuming wealth other than creating medium of exchanges.

\subsection{In the present system or practice of monetary and fiscal policies inflation and recession cannot be avoided}

\section{Inflation cannot be avoided}

The Austrian's notion (equally shared by all schools of economics) that, increase in inflation causes booms in the economy as prices rise and the buying capacity decreases and that as increase in inflation is caused due to increased money-supply, so money-supply should be controlled or reduced. However, boom would not happen if money were supplied according to the increased need of demand for money (due to decrease in money's purchasing power or due to price-inflation) to help the buying capacity remain stable. The only way to escape boom phase is not to stop or reduce money-supply but to increase supply of money corresponding to the increased demand for money. Again, inflation will increase primarily due to payments of interest and taxes. Money has to be injected into economy through lending. Government is also bound to receive money as tax and borrowing. Thus increase in inflation and 
corresponding increase in money-supply will or must continue. On the other hand controlling the moneysupply will cause boom phase in the economy as there would be little money to buy the products that has already been marketed for sale

\section{Recession cannot be avoided}

The notion that all schools of economics including the Austrians equally share, that somehow recession could be avoided or eliminated for ever is wrong. Recession is caused due to business-failures. Whether you increase or decrease money-supply and whether the money is based on any metal standard or fiat money, you cannot stop business failures. Recession is declared to occur when a large portion of corporate sector fails, and you cannot eliminate the chances of their failure. Recession will occur; there is no way to stop it. Money has to be supplied to the economy if anybody wants to borrow money to keep pace with the growing demand for money as the economic activity (the market) is ever growing. The central bank can only reduce (not increase as it is practiced now) the interest rate as low as possible so that inflation (price-increase) remains low. Therefore, in the present practice of monetary and fiscal policies, boom-bust cycle cannot be avoided.

Mises himself accepted that the boom-bust cycle cannot be avoided. He writes, "the recurrence of periods of boom which are followed by periods of depression, is the unavoidable outcome of the attempts, repeated again and again, to lower the gross market rate of interest by means of credit expansion. There is no means of avoiding the final collapse of a boom brought about by credit expansion. The alternative is only whether the crisis should come sooner as the result of a voluntary abandonment of further credit expansion, or later as a final and total catastrophe of the currency system involved. ." [Mises 11 June 2010, Mises Daily Articles]

Then why does the Austrian School want to abolish government's monopoly power of printing money and allow the Private Banks to issue money? The answer is that they are concerned not to eliminate boom-bust cycle but to save Western Civilization from sliding into socialism. They want pure capitalist system of economy by privatizing the power of money-issuing. Mises wanted "to inoculate the market economy from the boom-bust cycle by purging money and banking of their interventionist elements. In making his case for the gold standard and 100-percent-reserve banking, Mises was making his case for the market economy and, in so doing, striving to rescue Western civilization from its slide into socialism." [Herbener 2002, pp. 90-91].

\section{16. Austrian school's explanation of "Stable Money" is a Utopia}

Hayek argues, "money renders one service, namely that as a unit of account, which makes stability of value the most desirable of all." [Hayek (1976) 1990, p. 67] "The amount required of any currency will always be that which can be issued or kept in circulation without causing an increase or decrease of the aggregate (direct or indirect) price of the 'basket' of commodities supposed to remain constant." [Hayek (1976) 1990, p. 89] "There will always be one or more issuers who find it to their advantage to regulate the supply of their currency so as to keep its value constant in step with the aggregate price of a bundle of widely used commodities. This would soon force any less provident issuers of competing currencies to put a stop to a slide in the value of their currency in either direction if they did not wish to lose the issue business altogether or to find the value of their currency falling to zero." [Hayek (1976) 1990, p. 95] Hayek writes that if he were a manager of a bank, "I would further announce my intention, although without assuming a legal obligation, to control the quantity of this issue so as to keep its purchasing 
power as nearly constant as possible (measured against a specified list of commodities)." [Hayek, (1976)1990, p. 46] "I would add to this announcement that I fully understood that the success of my business, which should be very profitable since I would lend money, depended on my meeting the public's expectation that I maintain my currency at the announced real value. I am convinced that I could satisfy this expectation.” [Hayek (1976)1990, p. 46]

Austrian economists argue, if money were only on commodity (gold) then the value of both money and commodity would remain constant. Herbener wrote, "Mises advanced his proposal for a monetary system with zero credit expansion, that is, a gold standard with no issue of fiduciary media, as part of his program for monetary reform as early as 1944, and he repeated it in his 1952 essay on monetary reconstruction." [Herbener, p.89] Mises wrote, "The significance of the fact that the gold standard makes the increase in the supply of gold depend upon the profitability of producing gold is, of course, that it limits the government's power to resort to inflation." Ravier writes, "Friedrich Hayek worked towards prescribing a monetary policy under which the world economy would again enjoy the stability it had known under the classical international gold standard system." [Ravier No date]

However, Hayek could not stick to his theory of $100 \%$ commodity money because that would restrict the money supply. Therefore, he skips from his theory that money's value will remain stable if money is pegged to commodity only. He began to argue that to keep money's value stable, it is not necessary for money to be issued against any commodity. He argues even if money is issued as fiat, money's value may remain stable if somehow money supply can be controlled to keep the purchasing power of money constant. He [Hayek] writes "I would announce at the same time my intention to regulate the quantity of the ducats so as to keep their (precisely defined) purchasing power as nearly as possible constant." [Hayek (1976)1990, p. 46].

There is a contradiction. On the one hand, more money supply is needed to meet the increasing demand for money. On the other hand, increase in money supply leads to consumer price index. The Austrian economists prefer keeping purchasing power of money constant to supplying money against the demand for supply of more money.

Hayek believes that money's purchasing power can be controlled even if it is not commodity money but fiat money. Hayek thinks that the competition among issuers of fiat currencies would ensure stable money. He writes, "Competition would certainly prove a more effective constraint, forcing the issuing institutions to keep the value of their currency constant (in terms of a stated collection of commodities), than would any obligation to redeem the currency in those commodities (or in gold)." [Hayek (1976)1990, p. 48] Hayek writes, "what I mean by being stable in purchasing power, but briefly, I mean a kind of money in terms of which it is equally likely that the price of any commodity picked out at random will rise as that it will fall. Such a stable standard reduces the risk of unforeseen changes in the prices of particular commodities to a minimum, because with such a standard it is just as likely that any one commodity will rise in price or will fall in price and the mistakes which people at large will make in their anticipations of future prices will just cancel each other because there will be as many mistakes in overestimating as in underestimating. If such a money were issued by some reputable institution, the public would probably first choose different definitions of the standard to be adopted, different kinds of index numbers of price in terms of which it is measured; but the process of competition would gradually teach both the issuing banks and the public which kind of money would be the most advantageous." [Hayek April 2019, p.3]

However, he is wrong. In this situation money-issuers will be lured to inflate the money as much as they can and thus there will be a flood of money causing unprecedented price-rise of commodities. Hülsmann argues, "Each bank has an incentive to be especially reckless in diminishing its reserves (issuing further notes without coverage) because it can rely on the other banks as some sort of a safety net." [Hülsmann 
2004, p. 51] However, Hayek argues that, though "There will of course always be a strong temptation for any bank to try and expand the circulation of its currency by lending cheaper than competing banks; but it would soon discover that, insofar as the additional lending is not based on a corresponding increase of saving, such attempts would inevitably rebound and hurt the bank that over-issued." [Hayek (1976)1990, p. 63] However, Hayek's argument is not tenable in actual economy. The users of money cannot know whether the money-issuers are issuing their money against any reserve or not. Besides, "The problem of over-issue of money will be felt after a long run when there will be inflation (price-rise of commodities). And it is also not be possible to ascertain increase in money-supply of which banker (as there are many money-issuer) is responsible for the price-inflation." [Huerta de Soto, 2009, p. 422]

Hayek identifies the monetary stability with the stability of the purchasing power. However, purchasing power of money (PPM) can never be constant. Hülsmann points out: "First of all notice that the notion of "purchasing power of money" (PPM) cannot be given an impartial definition. The PPM is in fact the total array of things for which a unit of money can be exchanged. If the price of telephones increases while the price of cars drops, it is impossible to say by any impartial standard whether the PPM has increased or decreased. ... For one thing, the constituents of the price index are in need of incessant adaptation (they need to be changed) to take account of the changes in the array of goods and services offered on the market in exchange for money. Moreover, and most importantly, no such index conveys generally valid information. Different persons buy different goods; therefore, some of them might experience a rise of prices (of the prices they have to pay) while others experience a drop of (their) prices in the very same period." [Hulsmann 2008, p. 77] However, Hulsmann himself contradicts his reasoning when he argues that only commodity standard of money actually can ensure the stability of the PPM, since "when mining is less profitable than other branches of industry - which tends to be the case when the price level is high - then less money will be produced and money prices will tend to decline. And when mining is more profitable - usually when the price level is low-then more money will be produced and money prices will therefore tend to rise" [Hülsmann, 2008, p. 73]

However, the purpose of issuing (lending) money is not to keep the value of the 'basket' of commodities supposed to remain constant. Money is lent when creditworthy borrowers demand money. If money is tied to the basket of commodities then banks will not be able to lend the amount of money that their clients want to borrow. That will have harmful effect on the economy. Again, if new private banks begin to issue money, then the aggregate supply of money will automatically increase. When all the money (issued by all banks) will be in supply, it will be impossible for a single bank to reduce the supply of money to keep the value of its money stable or constant.

Hayek himself is not sure that it is possible to keep money's purchasing power stable. He writes, "Strictly speaking, in a scientific sense, there is no such thing as a perfectly stable value of money - or of anything else. Value is a relationship, a rate of equivalence, or, as W. S. Jevons said, 'an indirect mode of expressing a ratio', which can be stated only by naming the quantity of one object that is valued equally with the 'equivalent' quantity of another object. Two objects may keep a constant relative value in terms of each other, but unless we specify the other, the statement that the value of something is unchanged has no definite meaning." [Hayek (1976) 1990, p. 69-70]

Mises thought that it would be ideal if money's value (purchasing power) would remain invariable (stable or constant). However, he observes that money's value does not remain invariable (stable). Herbener explains Mises position thus: "Although it is easy to imagine a situation in which the value of money falls by a constant rate, Mises denied that anyone could put such a monetary system into effect [in stabilizing the value of money]." [Herbener 2002, p. 69] "Mises thought it impossible to distinguish the causal forces behind a change in prices merely from the knowledge of the price changes themselves.... [and observed that] one cannot distinguish from this fact alone whether the change is an increased demand for the good or a decreased demand for money. In fact, they are two ways of looking at the same thing." [Herbener 
2002, pp. 68-69] Mises argued that we cannot even try to stabilize the value of money. He wrote, "we have no useful knowledge of the quantitative significance of given measures intended to influence the value of money. More serious still is the circumstance that we are by no means in a position to determine with precision whether variations have occurred in the exchange value of money from any cause whatever, and if so to what extent, quite apart from the question of whether such changes have been effected by influences working from the monetary side. Attempts to stabilize the exchange value of money in this sense must therefore be frustrated at the outset by the fact that both their goal and the road to it are obscured by a darkness that human knowledge will never be able to penetrate." [Mises, 1980, p. 269] Mises argues that as we cannot definitely say how much additional supply of money will lead to how much changes in prices, so, collecting any data regarding the money-supply and the price-changes will not help us to calculate how additional money we should supply for how much changes in priceindexes or for keeping the value of money (or purchasing power of money) stable. Mises writes, "we do not so much as know the quantitative significance of variations in the quantity of money. We cannot calculate the intensity with which definite quantitative variations in the ratio of the supply of money and the demand for it operate upon the subjective valuations of individuals and through these indirectly upon the market. This remains a matter of very great uncertainty. In employing any means to influence the value of money we run the risk of giving the wrong dose. This is all the more important since in fact it is not possible even to measure variations in the purchasing power of money. Thus even though we can roughly tell the direction in which we should work in order to obtain the desired variation, we still have nothing to tell us how far we should go, and we can never find out where we are already, what effects our intervention has had, or how these are proportioned to the effects we desire." [Mises, 1980, pp. 256-57] Mises argued that as it is not certain whether money's purchasing power is influenced by the amount of money-supply or amount of commodity-supply or for changes in buyers' preferences, so it is not advisable to influence the price index through any monetary policy (that is increasing or decreasing the money-supply). Mises argue that if government becomes the sole authority of determining how much money is to be supplied, the government (in response to political pressure) will expand the supply of money and thus will cause greater destabilization in money's purchasing power. "Mises thought the fundamental problem in conducting monetary policy that targeted money's exchange value was the impossibility of bifurcating goods side and money-side influences on the purchasing power of money. No one can detect from any particular change in price of something what the underlying causal force is, whether it is goods side or money side. Therefore, one cannot find an accurate quantitative division of the total change in price into goods-side and money-side influences. Absent this division, one cannot determine the correct dose of monetary expansion or contraction, or even whether the money supply should be increased or decreased to hit the target. Mises did argue ... that there is no unique, correct way to construct a price index and thus, using some price index as a measure of changes in money's purchasing power is arbitrary and the selection of which one to use is then subject to political pressure." [Herbener 2002, p.71]

Mises argued that supply of money should, therefore, be left to the natural supply of metallic money like gold and silver money and government should not arbitrarily influence the money-supply by creating more fiduciary money. "Mises concluded that a gold standard eliminates any arbitrary influence on money's purchasing power from the money side. Without this source of "instability," the gold standard is in theory more "stable," than a fiat money standard." [Herbener 2002, p.70] Mises wrote, "The significance of adherence to a metallic-money system lies in the freedom of the value of money from state influence that such a system guarantees. . . . It is true that [money-side] effects, in the case of gold (and even in the case of silver), are not immoderately great, and these are the only two monetary metals that need be considered in modern times. But even if the effects were greater, such a money would still deserve preference over one subject to state intervention, since the latter sort of money would be subject to still greater fluctuations." [Mises, 1980, p. 270] "What makes the managed monetary system less stable than the gold standard, according to Mises, is that it lacks this policy-induced money-side influence on money's purchasing power." [Herbener 2002, p.73] "One of the distinguishing features of Mises's 
monetary theory is his position that monetary stability is a chimera. Mises was fully aware that no monetary system, the gold standard included, could be judged on this ground. "The purchasing power of gold is not stable," he wrote, "but the very notions of stability and unchangeability of purchasing power are absurd." Even so, what Mises claimed for the gold standard is that "nobody is in a position to tell us how something more satisfactory could be put in [its] place." Mises did not think that the gold standard was the best monetary system because it was the most stable. His defense of the gold standard on this point was that it fettered the inflationary impulse of government, not that it attained the utopia of stability." [Herbener 2002, p.73]

In the above discussion, it is clear that money's purchasing power will be more stable if money is created only on metallic standard (i.e. gold and silver) and if government (for that matter any money-issuing authority) does not create money (fiat or fiduciary) more than the metal can support (as reserve), because increase in the money supply increases the inflation rate and thus causes reduction in money's value (purchasing power). Mises supported the gold standard because, "in fact fiat-paper standards have had more extreme episodes of price inflation than gold standards. The theoretical demonstration of why one should expect to find this result in history is his argument about the political impetus to inflate with a managed fiat-money System" [Herbener 2002, p.75] "Mises thought that a government-regulated [free banking] money system [in which government will allow money-issuing authority to create only metal money and not any fiat or fiduciary money] was necessary to achieve the ideal "of enlightened statesmen and economists" [that is to keep money's purchasing power comparatively stable]" [Herbener 2002, p.68] Mises argued, "nobody is in a position to tell us how something more satisfactory could be put in [its] [of gold standard] place." [Quoted in Herbener 2002, p.73]

Therefore, Hayek says that "Our only hope for a stable money is indeed now to find a way to protect money from politics." [Hayek (1976) 2009, p. 16] Hayek argues, "under the proposed scheme, the managers of the bank would learn that its business depended on the unshaken confidence that it would continue to regulate its issue of ducats (etc.) so that their purchasing power remained approximately constant." [Hayek (1976) 1990, p.49] "To achieve its announced aim of maintaining the purchasing power of its currency constant, the amount would have to be promptly adapted to any change of demand, whether increase or decrease. Indeed, so long as the bank succeeded in keeping the value of its currency constant, there would be little reason to fear a sudden large reduction of the demand for it (though successful competitors might well make considerable inroads on its circulation)." [Hayek (1976) 1990, p. 49] "A real difficulty could arise if a sudden large increase in the demand for such a stable currency, perhaps due to some acute economic crisis, had to be met by selling large amounts of it against other currencies. The bank would of course have to prevent such a rise in the value and could do so only by increasing its supply. [Hayek (1976) 1990, p. 50]

\section{Assessment of Austrian school's explanation of "Stable Money"}

However, increase or decrease in commodity-money in relation to decrease or increase in prices of other commodities cannot ensure the stability of the purchasing power of money (PPM), because, in that case, prices of commodities are bound to fluctuate with the increased or decreased supply of commodity money. Huerta de Soto writes, "Hayek demonstrates that a policy of stabilizing the purchasing power of the monetary unit is incompatible with the necessary function of money with respect to coordinating the decisions and behaviors of economic agents at different points in time." [Huerta de Soto 2009, pp. 427428]

Therefore, the Austrians' expectation of stabilizing the PPM is a utopia.

If private banks are allowed to issue money, both the money-issuing banks and the public jointly will ensure stable money. On the one hand public will prefer the most stable currency which will secure more 
stable business. Hayek wrote, "If we are right that, being able to choose, the public would prefer a currency whose purchasing power it could expect to be stable, this would provide a better currency and secure more stable business conditions than have ever existed before." [Hayek (1976) 1990, p. 101] On the other hand the money-issuer banks will provide stable money to secure their individual gain. Hayek wrote, "It proves in fact wholly to be the result of government preventing private enterprise from working freely and providing itself with a money that would secure stability. We have seen that there can be no doubt that free enterprise would have been both able to provide a money securing stability and that striving for individual gain would have driven private financial institutions to do so if they had been permitted." [Hayek (1976) 1990, p. 101]

\subsection{Austrian School's opinion that the government plunders and misuses money is unfounded; Government does not plunder}

Austrian school thinks that government cheats and defrauds people and plunders money through printing money and forces the productive to support the unproductive. The following excerpts from the writing of the economists of Austrian school are self-explanatory.

"it can be said without qualifications, [that government] have incessantly and everywhere abused their trust to defraud the people." [Hayek (1976) 1990, p. 30] "the introduction of paper money provided governments with an even cheaper method of defrauding the people." [Hayek (1976) 1990, p. 34] "money's evolution has been constantly "diverted" from what would have been its market-determined course by governments and political authorities that saw in its control an ability to plunder the wealth of entire populations." [Ebeling 2012 Aug, p. 11]

"if the government resorts for this purpose to inflation, it is employing methods which are contrary to the principles of representative government, although formally it may have fully complied with the letter of the constitution. It is taking advantage of the masses' ignorance, it is cheating the voters instead of trying to convince them." [Mises 1953, p. 428] "The most frequent reason for printing more money is the existence of an unbalanced budget. Unbalanced budgets are caused by extravagant expenditures which the government is unwilling or unable to pay for by raising corresponding tax revenues. The excessive expenditures are mainly the result of government efforts to redistribute wealth and income -- in short, to force the productive to support the unproductive. This erodes the working incentives of both the productive and the unproductive." [Hazlitt Sept 1978]

\section{Assessment of Austrian School's views on what government does with money}

Thus, according to the Austrian school, by increasing the supply of fiat-money, government deprives the people of their resources for its own purpose. Salerno writes, "In this way [increasing fiat-money], the national government is able to divert scarce resources from private uses and utilize them for its own purposes." [Salerno 1982, p. 1]

Government does not target "increasing the supply of fiat-money"; it targets public services \& works and increasing employment. It is not plunder, what government does with money is for the benefit of the whole nation that is the entire population through public works for public use.

Hayek thinks that the government just gives away more money to the people who want to have more money to hold and that such act on the part of the government is a criminal offence. He writes, "To provide a medium of exchange for people who want to hold it until they wish to buy an equivalent for what they have supplied to others is a useful service like producing any other good. If an increase in the demand for such cash balances is met by an increase of the quantity of money (or a reduction of the 
balances people want to hold by a corresponding decrease of the total amount of money), it does not disturb the correspondence between demand and supply of all other commodities or services. But it is really a crime like theft to enable some people to buy more than they have earned by more than the amount which other people have at the same time foregone to claim." [Hayek (1976) 1990, p. 104]

This very concept of the Austrian school of economists that government just distributes money to those who wants more money just to hold is flatly wrong. Government does not just give away money. It buys commodities in kinds and services and thus helps people to sell their labour and/ or products of their labour so that they may earn money for buying other goods and services that they do not produce but need to consume. Therefore, government's expenditure helps production and distribution. Government also does not produce money. Its income comprises of tax and proceeds of bond-sales. Government also does cause any inflation (both increase in money supply and commodity prices) as government does not buy anything above market prices. Therefore, Austrians school's prescription for abolition of government's power for supplying money is just a recommendation to abolish what does not really exist or has been abolished long before.

\section{18. Austrian school's argument, that Government crates money, is wrong}

Austrian economists believe that as government creates money. Mises wrote, "The power to issue money was essential for the finance of the government ... in order to give to government access to the tap where it can draw the money it needs by manufacturing it." [Hayek April 2019, p. 3] Therefore, "History certainly disproves the suggestion that in this respect government, which only profits from excessive issues, can be trusted." [Hayek (1976) 1990, p. 113]

Thus, the Austrian Economists believe (all schools of economics also share the same view) that government creates and issues money. However, they are wrong. Nowadays, government does not create or issue money. Besides, the central bank does not give or any money to the government. Therefore, the question does not arise that government will be lured to print fiat-money for the purpose of funding its deficit budget. Besides, government spending does not at all increase money supply. Government gets fund from tax and bond-sale. The money that the government gets from tax receipts bond-sales has already been supplied to the economy and is in circulation. Government takes the money from the nongovernment sector and spends it to the non-government sector. Therefore, no question arises that government-spending increases the money-supply in the economy. Government also does not buy anything at a price that is above the market price. So, no question can be raised that government spending causes increase in market-prices. Therefore, no question arises to deprive the government of its power to issue fiat-money (non-commodity-money) on the wrong assumption (diagnosis) that government inflates the money supply or government-spending increases the market price or that government "profits from excessive issues" of money.

\section{Assessment of Austrian school's theory that government creates money}

No, government cannot create (take loan) unlimited new money at will. It is the central bank of every nation that has the absolute authority to create and supply money to the economy and to frame monetary policy. Ebeling wrote, "A central-banking structure for the management and control of a gold-backed currency was established in each country by its representative government, either by giving a private bank the monopoly control over gold reserves and issuing banknotes or by establishing a state institution assigned the task of managing the monetary system within the borders of a nation. The United States was 
the last of the major Western nations to establish a central bank, but it finally did so in 1913." [Ebeling 2012, p 4]

Government sells its bonds to finance its deficit budget. Central bank does not buy government bonds directly. The non-government sector (people, corporate, banks and other financial and non-financial institutions) buy those government bonds. Government is bound to repay its debts to the bond-holders after the maturity of the bonds. Therefore, government can borrow only that much money (not as much money as it wishes) that it will be able to repay along with accrued interest at the maturity of the bonds. Therefore, government can take only that amount of money that it will able to repay from the future taxearning. Government has no other way but to collect tax to be able to spend.

Therefore, it is not true that government creates and spends as much money as it wishes.

\section{19. Austrian School's understanding of Fractional Reserve Banking is fallacious}

\section{Fractional reserve banking}

This School is of the opinion that the commercial banks create some kind of money that is not created by the central bank. This School opines that the banks create those unbacked money through fractional reserve banking system. Rothbard explains that commercial banks can create money in two different ways.

One type of reserve banking is when banks create more money than its reserve can support. Rothbard argues:

"Suppose now that banks yield to the temptation to create fake warehouse receipts to cash, and lend these fake receipts out. What happens now is that the previously strictly separate functions of loan and deposit banking become muddled; the deposit trust is violated, and the deposit contract cannot be fulfilled if all the "creditors" try to redeem their claims. The phony warehouse receipts are loaned out by the bank. Fractional-reserve banking has reared its ugly head.

Thus, suppose that the Rothbard Deposit Bank [that has cash deposit of $\$ 20,000$ ] in the previous table decides to create $\$ 15,000$ in fake warehouse receipts, unbacked by cash, but redeemable on demand in cash, and lends them out in various loans or purchases of securities. For how the Rothbard Bank's balance sheet now looks see Figure 5:

\begin{tabular}{|c|c|}
\hline $\begin{array}{l}\text { Figure } 5 \\
\text { Fractional-Reserve Banking }\end{array}$ & \\
\hline Rothbard Deposit Bank & \\
\hline Assets & Equity + Liabilities \\
\hline $\begin{array}{l}\text { Cash: } \$ 20,000 \\
\text { IOUs from Debtors: } \$ 15,000\end{array}$ & Warehouse Receipts to Cash: $\$ 35,000$ \\
\hline Total: $\$ 35,000$ & Total: $\$ 35,000$ \\
\hline
\end{tabular}

In this case, something very different has happened in a bank's lending operation. ... The money supply has increased because warehouse receipts have been issued that are redeemable in cash but not fully backed by cash." [Rothbard 2007, pp.48-49]

Thus, according to Rothbard, banks can increase their un-backed money to any unlimited amount. 


\section{Rothbard gives an example of a second type of money creation by commercial banks. It is fractional reserve banking system. He argues:}

"Suppose that the Fed decides it wishes to expand the nation's total money supply by $\$ 10$ billion. If the money multiplier is 10 , then the Fed will choose to purchase $\$ 1$ billion of assets, generally U.S. government securities, on the open market. ... Note that the immediate result of the Fed's purchase of a $\$ 1$ billion government bond in the open market is to increase the nation's total money supply by $\$ 1$ billion. But this is only the first, immediate step. Because we live under a system of fractional-reserve banking, other consequences quickly ensue. There are now $\$ 1$ billion more in reserves in the banking system, and as a result, the banking system expands its money and credit, the expansion beginning with Chase and quickly spreading out to other banks in the financial system. In a brief period of time, about a couple of weeks, the entire banking system will have expanded credit and the money supply another $\$ 9$ billion, up to an increased money stock of $\$ 10$ billion. ... Figure 11, then, shows the consequences of the Fed purchase of $\$ 1$ billion of government bonds after a few weeks.

Figure 11

Fed Buys a \$1 Billion Bond:

Result After a Few Weeks

\section{Commercial Banks}

\begin{tabular}{|l|l|}
\hline Assets & Equity + Liabilities \\
\hline $\begin{array}{l}\text { Loans and securities: }+\$ 9 \text { billion } \\
\text { (Reserits at Fed }\end{array}+\$ 1$ billion & Demand deposits: $+\$ 10$ billion \\
\hline
\end{tabular}

\section{The Federal Reserve}

\begin{tabular}{|l|l|}
\hline Assets & Equity + Liabilities \\
\hline U.S. Government & $\begin{array}{l}\text { Demand deposits to banks: } \\
+\$ 1 \text { billion }\end{array}$ \\
\hline Securities: $+\$ 1$ billion & \\
\hline
\end{tabular}

... The change in totals has taken place among the commercial banks, who have pyramided credits and deposits on top of their initial burst of reserves, to increase the nation's total money supply by $\$ 10$ billion." [Rothbard 2007, pp. 139-142]

\section{Assessment of Fractional reserve banking cum circulation of credit system}

It should be noted here that though, in the past, the banks could create more money than their commodity (gold and silver) could support, nowadays only the central bank can create money and commercial banks are prohibited to create any money. Commercial banks are only intermediaries between the depositors or lenders (individuals, other banks, corporate, governments and even the central bank) and the borrowers (individuals, other banks, corporate, governments and even the central bank). Therefore, Rothbard's first example of creation of $\$ 15000$ more dollars is not correct. Commercial Banks cannot create any money; they just borrow and lend. "In each country its governmental "Central Bank" (in the United States, the Federal Reserve) is the sole monopoly source and creator of all money". [Rothbard 2007, p. 11]

In the second type of fractional reserve banking, creation of $\$ 9$ billion over a deposit of $\$ 1$ billion by the commercial bank is not also possible. Because the money ( $\$ 9$ billion) that is supposed to be created through fractional reserve banking is not created at all; what is created is "open book deposit account" or "checkable account". 
Under fractional reserve banking after each successive deposit, money equal to the reserve requirement is withdrawn from the banking system and is deposited in the central bank. At the logical end of the fractional reserve banking, the consecutive deposits piles up to $\$ 9$ billion and the money deposited in the central bank as reserve requirements by the commercial banks after every deposit they received also piles up to $\$ 1$ billion which is the initial sum. Thus, after the logical end of the fractional reserve banking, there remains no central bank money (of the initial deposit) outside the central bank. No money is left in the banking system or in the economy. The banks can neither lend nor receive any repayment from their borrowers nor will be able to honor any request for withdrawal from its depositors. Therefore, though there is IOUs (deposits) of $\$ 9$ billion, yet there is no money in the banks. Therefore, only IOUs (deposits) of $\$ 9$ billion are created, no money is created or increased. On the other hand, after each successive deposit, available amount of the initial sum is reduced because money went to the central bank to the extent of reserve requirement when each deposit is made. At the logical end of the fractional reserve banking, if any person issues a check on this account, he cannot use any money from his "checkable account". It is misleading that banks can increase initial deposit through the practice of fractional reserve banking.

Rothbard himself accepts that money and the checkable account are not the same. He writes, "This transfer order has come to be known as a "check," and the open book deposit account at the bank as a "demand deposit," or "checking account."' [Rothbard 2007, p. 55] "But even though the bank note and the demand deposit are economically equivalent, the two forms will not be equally marketable or acceptable on the market. The reason is that while a merchant or another bank must always trust the bank in question in order to accept its note, for a check to be accepted the receiver must trust not only the bank but also the person who signs the check." [Rothbard 2007, p. 57]

Rothbard himself gives an example that by lending the deposit, the bank does not fraudulently create money. Rothbard argues:

“"Most people, however, think of "banks" as borrowing money from one set of people, and relending their money to another set, charging an interest differential because of its expertise in lending, in channeling capital to productive businesses. How would this sort of borrow-and-lend bank operate?

Let us take the Rothbard Loan Bank, as shown in Figure 3, and assume that the Bank borrows money from the public in the form of Certificates of Deposit (CDs), repayable in six months or a year. Then, abstracting from the interest involved, and assuming the Rothbard Bank floats \$40,000 of CDs, and relends them, we will get a balance sheet as follows:

Figure 3

The Loan Bank Borrows Money

\begin{tabular}{|l|l|}
\hline Assets & Equity + Liabilities \\
\hline Cash: $\$ 1,000$ & Owed in CDs: $\$ 40,000$ \\
IOUs: $\$ 49,500$ & Owned by Rothbard: $\$ 10,500$ \\
\hline Total: $\$ 50,500$ & Total: $\$ 50,500$ \\
\hline
\end{tabular}

Again, the important point is that the bank has grown, has borrowed and reloaned, and there has been no inflationary creation of new money, no fraudulent activity, and no counterfeiting. If the Rothbard Bank makes a bad loan, and becomes insolvent, then that is a normal entrepreneurial error. So far, loan banking has been a perfectly legitimate and productive activity." [Rothbard 2007, p. 32-33] 
Thus, banks merely function as intermediaries and "Financial intermediation was useful because it prevented that savings remained dormant in idle money hoards". [Hulsmann 2015]

Hayek writes, "deposits subject to cheque played very much the same role, and could be created by the commercial banks in exactly the same manner, as bank notes." [Hayek (1976) 1990, p. 91] This notion (also equally shared by all shades of economics including the Austrians) that the commercial banks increase money-supply by lending credit to the borrowers either multiplying its reserve through fractional reserve banking or by creating money out of nothing is also grossly wrong. It is argued that through fractional reserve banking banks can multiply its reserve to the extent of ten times if the required reserve ratio becomes $10 \%$. However, it is not correct. The fact is that at the end of the process of consecutive depositing and lending, all the $100 \%$ of initial reserve will go to the central bank as required reserve ratio. No money will be left either in the bank's reserve or in the hands of the bank's customers (depositor or borrower). Therefore, banks cannot multiply or increase money through the process of reserve banking, but reduces the money supply from the circulation. Commercial banks also cannot create money out of nothing. The fact is that when bank lends money (credit) to its borrowers, it lends from its deposit reserves and if deposit reserve falls short of money it takes loan from its customers (other banks, central bank or other depositor) to fill in the shortage of money.

Therefore, it is wrong that banks can create money either through fractional reserve banking or from out of nothing as the Austrians (and all other school of economics) think it to be.

\section{20. Austrian School's demand that people should have the right to issue their own money and to trade in that money will create chaos in the economy}

\section{Government protects from violence and aggression but controls private property by controlling creation and injection of money. 8. Private banks should be given right to create money}

Regarding government's function, Mises wrote that "[it] is a guarantor of liberty and is compatible with liberty only if its range is adequately restricted to the preservation of economic freedom." [Mises 1998, p. 720] "In short, the liberal society is achieved when state coercion is limited to defense of person and property." [Herbener 2002, p. 80] "In freedom, the money and banking industry can create sound and honest currencies, just as other free industries can provide efficient and reliable products. Freedom of money and freedom of banking, these are the principles that must guide our steps." [Hans Sennholz, Money and Freedom (Cedar Fall, IA: Center for Futures Education, 1985) pp. 77 \& 83] [Quoted in Ebeling 2012, p. 12] "Mises argued that money, like all other goods, is part of the private property order of the market, and thus, outside the realm of state power, which was to be restricted to defense of person and property." [Herbener 2002, p. 80] Hayek writes that, "I think if the capitalists had been allowed to provide themselves with the money which they need, the competitive system would have long overcome the major fluctuations in economic activity and the prolonged periods of depression." [Hayek 1979, pp.313-314]

Explaining the essence of 'Denationalisation of Money', Geoffrey E. Wood writes, "In general, competition will deliver the best attainable outcome. Why not in money? That is the question addressed in this Paper; and the answer is that competition in the supply of money will produce that desired outcome, just as it does in other economic activities." [Hayek (1976) 1990, p. 21] Arthur Seldon writes, "Professor Hayek is arguing that money is no .different from other commodities and that it would be better supplied by competition between private issuers than by a monopoly of government." [Hayek (1976) 1990, Preface, p 9] In his book Denationalisation of Money (Hayek, 1990), Hayek argues "against a governments monopoly of issuing money and claims that every person, or institution, should have a right to issue his own money (either commodity or fiat)." [Sieron Undated, p.1] 


\section{Austrian economists argue that private individuals should be given the right to create their own money:}

"the people have never been given the opportunity to discover this advantage. Governments have at all times had a strong interest in persuading the public that the right to issue money belongs exclusively to them." [Hayek (1976) 1990, p. 28] "The private citizens of every country should be allowed, by mutual agreement, to do business with each other in the currency of any country. In addition, they should be allowed to mint privately gold or silver coins and to do business with each other in such coins." [Salerno 1982 , p. 2] "Under a pure commodity money, the money-supply process is totally privatized: The mining, minting, certification, and storage of the money commodity as well as the issuance of fully covered, i.e., 100-percent gold-backed, bank notes and deposits are carried out by private firms operating in a free market." [Salerno 1982, p. 2] "I think if the capitalists had been allowed to provide themselves with the money which they need, the competitive system would have long overcome the major fluctuations in economic activity and the prolonged periods of depression." [Hayek 2019 April, p.6]

Thus, the Austrians claim that money is commodity and everybody must have the right to issue own money (commodity or fiat) and to his deal in that money as everybody enjoys the right to deal in other commodities. They also argue that people should have the right to chose any commodity as money and that every individual should have the right to refuse to accept any commodity-money that he thinks bad money. Austrians claim if a system of money-creation could be done according to their suggestions of free-market commodity-money, then the economy will be far better than the present system of fiat-money making that is going on under the (according to them) the arbitrary government.

\section{Assessment of the Austrian economists' argument that private individuals should be given the right to create their own money:}

However, the fact is that the system suggested by the Austrian will be chaotic and devastating. If every people would try to pass off his commodity as money and have the right to refuse others money then no exchange will take place at all. It will be like returning to the barter system where direct exchanges faced the problem of double coincidence of wants.

Besides, there will be so many types of money of so many commodities that people will be puzzled to chose which commodity-money they should accept so that they may buy their necessities in future, because there is every possibility of refusal to accept money by the seller of those necessary commodities. Then people will have to buy many types of commodity-money in the hope that sellers may choose to accept any one of those moneys. But they are not sure; seller may refuse to accept all types of money that a customer can pay with. Besides, it is not guaranteed that any banker will not issue more amount of paper-certificate (that is fiat money) than their commodity-reserve can support. Forgery, cheating, embezzlement, usury will be the rule of the day. No one will have any faith in others. Thus, monetary system will be thrown into the chaos. Exchanges could be done smoothly when there is only one universally accepted medium of exchange; too many money in a same zone of economic activity will create pandemonium. The Austrians themselves realized and accepted that they are not sure in what form this system of privately creation of money will take shape. Therefore, the system of single-type of moneycreation in the hands of the central bank is better than such chaotic system of private money-creation.

Austrian economists are not contented with their claim that people should have the right to issue their own commodity-money. They demand further that the people should have the right to issue fiat money 
also. However, they themselves accuse the central bank of creating fiat money fraudulently; and therefore, they demand abolition of the central bank so that fiat money cannot be created at all. Therefore, their demand for allowing the people to issue fiat money is against their original claim of abolishing fiat money.

Again, the commodity that is created for exchange and the money that is created out of the same commodity are different in their impacts on the economic activities. Austrian school demands that every people should have the right to issue their own money (commodity and or fiat). But in practice, every people is not in a position to create his own money. Any commodity can become money if it is generally accepted by all as medium of exchange. So, the commodity money must be durable, divisible and valuable. Only metals (like gold silver copper etc.) have such quality. Every people will not have the access to production of metal. Therefore, only those who have that capacity for mining metal can create commodity money. And the numbers of miners are very few. Therefore, only very few people will be able to create their own money. Most of the people will have to borrow money from those miner-cum-moneycreators. Therefore, money-makers will be profited at the cost of others whom they will lend money.

However, the Commodity and the Commodity money are different. Austrian School demands that as people can deal in any commodity so the people should have also the right to deal in commodity-money. However, the impacts on the economic activities of the commodity that is created for consumption and of the commodity money that is created to be used as medium of exchange are different. Suppose two persons employ their men and wealth equal to each other, but person A used his wealth for commodity(gold) money-creation and B used his wealth for dealing in gold. While the money-maker A will lend money to $\mathrm{C}$ and gets interest on it loosing no amount of his money and can buy his necessities out of the interest he earns, the gold-dealers must lose his gold for buying his necessities. To deprive the people from amassing such easy money through interest earning, government of every country has forbidden people to create money or to lend anything for usury purposes and given the power of creating money only to the central bank.

If individuals are allowed to create money, according to the wishes of the Austrians, then, there will be a competition among individuals to create money and the money-makers (issuing banks) will be benefitted at the cost of others doing nothing (producing no consumption goods or services). Therefore, Austrians are wrong in suggesting that every individual should have the right to issue money.

Besides, government does not control in any way the production of the commodity (of which money is made) and the selling and purchasing of that commodity. Nowhere and never was there any ban on dealing in gold and silver for the purpose of consumption like using as ornaments or holding. Government only controls money creation and banking whether it is commodity-money or non-commodity-money (fiat money) because if banking remains in the hands of private individual bankers will prosper at the cost of others and there will be complete chaos in financial and economic system.

\section{21. Austrian School's definition of Monetary Aggregate (Ma) is wrong}

The Austrian School does not believe in the quantity theory of money as they think whatever may be the quantity of money that is circulating; it (aggregate money supply) adjusts itself to the prices of the aggregate commodity that is in supply. However, going against their view that monetary aggregation are 
unnecessary and serve no useful purpose, they ultimately formulated a theory of aggregating the existing supply of money in a given economy.

Rothbard tried to explain Austrian School's concept of aggregate supply of money in his article "Austrian Definitions of the Supply of Money" that is included in a book titled "New Directions in Austrian Economics" between the pages 143 and 156, edited by Louis M. Spadaro, published by Sheed Andrews and McMeel from Kansas City in 1978.

Rothbard suggests that the aggregate money supply should include total supply of cash minus the amount of cash held in the banks plus "money-substitutes" like demand deposits, saving deposits and time deposits etc. that "function as equivalent to money in the market" "as if it were cash, a surrogate for money" [Rothbard 1978, p. 145] "In contemporary economics, definitions of the money supply range widely from cash + demand deposits (M1) up to the inclusion of virtually all liquid assets (a stratospherically high $M$ )". [Rothbard 1978, p. 144] But, Rothbard argues that assets like goods and services, though has some degree of liquidity, should not be included as part of the money supply. He writes, "The current tendency of some economists to include assets as money purely because of their liquidity must be rejected; after all, in some cases, inventories of retail goods might be as liquid as stocks or bonds, and yet surely no one would list these inventories as part of the money supply. They are other goods sold for money on the market." [Rothbard 1978, p. 151]

"since the concept of the supply of money is vital both for the theory and for applied historical analysis of such consequences as inflation and business cycles, it becomes vitally important to try to settle these questions, and to demarcate the supply of money in the modern world." [Rothbard 1978, p. 144] Mises explained money in "The Theory of Money and Credit" thus: "money is the general medium of exchange, the thing that all other goods and services are traded for, the final payment for such goods on the market." [Rothbard 1978, p. 144] Rothbard argues that as bank created deposits like demand deposits, saving deposits and time deposits conform Mises' definition of money, so those deposits should be treated as equivalent to money. Rothbard writes that Mises "pointed out, bank demand deposits were not other goods and services, other assets exchangeable for cash; they were, instead, redeemable for cash at par on demand. Since they were so redeemable, they functioned, not as a good or service exchanging for cash, but rather as a warehouse receipt for cash, redeemable on demand at par as in the case of any other warehouse." [Rothbard 1978, p. 145] Rothbard continues, "Demand deposits were therefore "moneysubstitutes" and functioned as equivalent to money in the market. Instead of exchanging cash for a good, the owner of a demand deposit and the seller of the good would both treat the deposit $a$ s if it were cash, a surrogate for money. Hence, receipt of the demand deposit was accepted by the seller as final payment for his product."[Rothbard 1978, p. 145] Therefore, Rothbard argues, "demand deposits must [be] included in the concept of the money supply so long as the market treats them as equivalent; that is, so long as individuals think that they are redeemable in cash." [Rothbard 1978, p. 146]

"Deposits are not in fact all redeemable in cash in a system of fractional reserve banking; but so long as individuals on the market think that they are so redeemable, they continue to function as part of the money supply. Indeed, it [deposit created by banks] is precisely the expansion of bank demand deposits beyond their reserves that accounts for the phenomena of inflation and business cycles." [Rothbard 1978, p. 146]

Rothbard argues that "if demand deposits are to be included in the money supply for this reason, then it follows that any other entities that follow the same rules must also be included in the supply of money." [Rothbard 1978, p. 147] Following this argument Rothbard suggests that all bank created deposits should form a part of the aggregate money supply. Those deposits are: demand deposits, saving deposits in 
commercial banks (included in M2) and in savings banks or savings and loan associations (also included in M3), small-denomination CDs (certificate of deposit), government bonds, and cash surrender values of life insurance policies etc. Rothbard suggests that the "demand deposits in the commercial banks or in the Federal Reserve Banks owned by the Treasury ... should be included in the national total of the money supply.” [Rothbard 1978, p. 153]

Rothbard writes, "Not only, then, should savings deposits be included as part of the money supply, but our argument leads to the conclusion that no valid distinction can be made between savings deposits in commercial banks (included in M2) and in savings banks or savings and loan associations (also included in M3).Once savings deposits are conceded to be part of the money supply, there is no sound reason for balking at the inclusion of deposits of the latter banks." [Rothbard 1978 p. 149]

Rothbard argues that as "Checks can be drawn on demand deposits." [Rothbard 1978, p. 147] so demand deposits must be treated as good as money. He also argues that though "they [saving deposits] cannot be used directly for payment. ... [and] savings deposits must first be redeemed in cash upon presentation of a passbook." [Rothbard 1978, p. 147] yet they should be treated as money. Because, "mere lack of activity of part of the money stock in no way negates its inclusion as part of ... supply of money. Similarly, the fact that passbooks must be presented before a savings deposit can be used in exchange should not negate its inclusion in the money supply." [Rothbard 1978, p. 148] Therefore, according to Rothbard, though the owners of saving deposits cannot use money instantly and must wait till saving deposits are redeemed into cash, yet saving deposits are included in the money supply.

Mises wrote: "It is usual to reckon the acceptance of a deposit which can be drawn upon at any time by means of notes or cheques as a type of credit transaction and juristically this view is, of course, justified; but economically, the case is not one of a credit transaction. If credit in the economic sense means the exchange of a present good or a present service against a future good or a future service, then it is hardly possible to include the transactions in question under the conception of credit. A depositor of a sum of money who acquires in exchange for it a claim convertible into money at any time which will perform exactly the same service for him as the sum it refers to has exchanged no present good for a future good. The claim that he has acquired by his deposit is also a present good for him. The depositing of the money in no way means that he has renounced immediate disposal over the utility it commands." [Mises, Theory of Money and Credit, p.268] [Quoted in [Rothbard 1978, p. 150]

However, the Austrian theory of Aggregate money supply differs from the Chicago School's definition of aggregate money supply. In contrast to Chicago School, Rothbard does not want to treat credit instruments like time deposits in savings banks and commercial banks, share certificates, Treasury bills, large-scale CDs, cash and the reserves of the commercial banks and demand deposits owned by noncommercial banks as part of money supply. He also argues that assets, though they have some degree of liquidity, should not be a part of money supply as "They are other goods sold for money on the market". [Rothbard 1978, p.151]

"On the other hand, a genuine time deposit — a bank deposit that would indeed only be redeemable at a certain point of time in the future, would merit very different treatment. Such a time deposit, not being redeemable on demand, would instead be a credit instrument rather than a form of warehouse receipt. It would be the result of a credit transaction rather than a warehouse claim on cash; it would therefore not function in the market as a surrogate for cash." [Rothbard 1978, p. 149] 
"It might be, and has been, objected that credit instruments, such as bills of exchange or Treasury bills, can often be sold easily on credit markets - either by the rediscounting of bills or in selling old bonds on the bond market; and that therefore they should be considered as money. But many assets are "liquid," i.e., can easily be sold for money. Bluechip stocks, for example, can be easily sold for money, yet no one would include such stocks as part of "the money supply. The operative difference, then, is not whether an asset is liquid or not (since stocks are no more part of the money supply than, say, real estate) but whether the asset is redeemable at a fixed rate, at par, in money. Credit instruments, similarly to the case of shares of stock, are sold for money on the market at fluctuating rates." [Rothbard 1978, p. 151]

Rothbard argues that only liquidity of some instrument or asset does not signify of their being part of money supply. He writes, "The operative difference, then is not whether an asset is liquid or not ... but whether the asset is redeemable at a fixed rate, at par, in money." [Rothbard 1978, p. 151] As credit instruments like shares of stock and assets (other goods) "are sold for money on the market at fluctuating rates" [Rothbard 1978, p. 151] so they should not form a part of money supply.

"Thus, we [the Austrian School of Economics] propose that the money supply should be defined as all entities which are redeemable on demand in standard cash at a fixed rate, and that, in the United States at the present time, this criterion translates into: $M a(a=$ Austrian $)=$ total supply of cash-cash held in the banks + total demand deposits + total savings deposits in commercial and savings banks + total shares in savings and loan associations + time deposits and small CDs at current redemption rates + total policy reserves of life insurance companies - policy loans outstanding - demand deposits owned by savings banks, saving and loan associations, and life insurance companies + savings bonds, at current rates of redemption. Ma hews to the Austrian theory of money, and, in so doing, broadens .the definition of the money supply far beyond the narrow $M 1$, and yet avoids the path of those who would broaden the definition to the virtual inclusion of all liquid assets, and who thus would obliterate the uniqueness of the money phenomenon as the final means of payment for all other goods and services." [Rothbard 1978, p. 153]

\section{Assessment of Austrian definition of Monetary Aggregate (Ma)}

This notion of the Austrian economists (that is equally shared by all schools of economics) that creditmoneys like saving deposits, fixed deposits, and travelers' checks created by the banks; bonds issued by the corporate and the governments; certificates of insurance companies etc. are moneys is grossly wrong. They are not moneys at all; they are only IOUs from the issuer of those financial instruments to the receivers/ holders of those instruments. The money against which those instruments (IOUs) is created is lying either with the issuer of those instruments or is invested in any business or transferred to other banks. Those IOUs can only be used only after they will be redeemed in cash. Therefore, those IOUs could not be treated as money and should not be included in aggregation of 'Ma' (as Austrian economists wants it $\mathrm{t}$ be) or M1, M2 or M3 etc (that other shades of economists thinks it to be). The fact is that other than the currency (digital, metal, paper money based on metal and fiat money), all that are included in M1 to MZM etc. or included in 'Ma' are only IOUs and not money at all. Increase of these IOUs does not increase money-supply in any way.

\section{22. Austrian economists are confused whether expansion or reduction in money supply will help economy to function smoothly}

Hayek argues that public interests will be served by the system of free issue of competitive currencies. He wrote, "The issuing banks, guided solely by their striving for gain, would thereby serve the public interest better than any institution was ever done or could do that supposedly aimed at it. There 
neither would exist a definable quantity of money of a nation or region, nor would it be desirable that the individual issuers of the several currencies should aim at anything but to make as large as possible the aggregate value of their currency that the public was prepared to hold at the given value of the unit." [Hayek (1976) 1990, p. 101]

Hayek thinks that the government monetary policy causes depressions. He writes, "What we should have learned is that monetary policy is much more likely to be a cause than a cure of depressions, because it is much easier, by giving in to the clamour for cheap money, to cause those misdirections of production that make a later reaction inevitable, than to assist the economy in extricating itself from the consequences of overdeveloping in particular directions." [Hayek (1976) 1990, p. 102] Hayek argues that government's monetary policy has led to the precarious condition of the economy, because due to government's monetary policy, money, instead being the regulator of the economy, became regulated by the market. He writes, "The past instability of the market economy is the consequence of the exclusion of the most important regulator of the market mechanism, money, from itself being regulated by the market process." [Hayek (1976) 1990, p. 102]

Hayek condemns government's inability to avoid inflating (increasing) the supply of money at the face of market demand for more money. However, Hayek himself accepts that money itself cannot regulate the economy but the market-price regulates the quantity of money to be supplied. He writes, "Money is not a tool of policy that can achieve particular foreseeable results by control of its quantity. But it should be part of the self-steering mechanism by which individuals are constantly induced to adjust their activities to circumstances on which they have information only through the abstract signals of prices." [Hayek (1976) 1990, p. 102]

Hayek argues that increasing expenditure by the government upsets the market economy. He writes, "The constant temptation to meet local or sectional dissatisfaction by manipulating the quantity of money so that more can be spent on services for those clamouring for assistance will often be irresistible. Such expenditure is not an appropriate remedy but necessarily upsets the proper functioning of the market.” [Hayek (1976) 1990, p. 103]

However, Hayek himself accepts that if, in an emergency, government is forced to increase its spending then market-economy will not be disturbed. He writes, "In a true emergency such as war, governments would of course still be able to force upon people bonds or other pieces of paper for unavoidable payments which cannot be made from current revenues. Compulsory loans and the like would probably be more compatible with the required rapid readjustments of industry to radically changed circumstances than an inflation that suspends the effective working of the price mechanism." [Hayek (1976) 1990, p. 103] If government's 'compulsory loans' do not 'upset' or destabilize the economy but becomes 'more compatible with the required rapid readjustment of industry', then, it is exactly what government really does. Government finances its deficit budget only by taking loan and spends to meet the increased demand for money by the market-economy. Therefore, following Hayek's argument, it can be said that the expenditure that the government incurs with the loans that it takes through selling bonds to the public, also will not 'upset' the market economy.

2.23. The Austrian School's explanation that increase in money-supply to mitigate the unemployment problem and the corresponding increase in minimum wage rates reinforce both inflation (increase in commodity price-index) and unemployment and ultimately lead to recession is a wrong diagnosis of the causes of recession

The Austrian school thinks that reduction of unemployment is possible only if money supply is increased continuously. However, continuous increase in money supply increases CPI continuously. If, in this continuous inflationary background, somehow, money-supply ceases to increase, sale of products 
(commodities) begins to decrease. This causes more unemployment. Therefore, they argue that moneysupply should not be increased but must be restricted or reduced.

"The modern expansion of government was largely assisted by the possibility of covering deficits by issuing money - usually on the pretence that it was thereby creating employment." [Hayek (1976) 1990, p. 33] However, "Neither higher wages nor higher prices of oil, or perhaps of imports generally, can drive up the aggregate price of all goods unless the purchasers are given more money to buy them. What is called a cost-push inflation is merely the effect of increases in the quantity of money which governments feel forced to provide in order to prevent the unemployment resulting from a rise in wages (or other costs), which preceded it and which was conceded in the expectation that government would increase the quantity of money. They mean thereby to make it possible for all the workers to find employment through a rise in the demand for their products. If government did not increase the quantity of money such a rise in the wages of a group of workers would not lead to a rise in the general price level but simply to a reduction in sales and therefore to unemployment." [Hayek (1976) 1990, p. 95, Italics added]

"Monetary policy is then faced with an unpleasant dilemma. In order to maintain the degree of activity it created by mild inflation, it will have to accelerate the rate of inflation, and will have to do so again and again at an ever increasing rate every time the prevailing rate of inflation comes to be expected. If it fails to do so and either stops accelerating or ceases to inflate altogether, the economy will be in a much worse position than when the process started." [Hayek (1976) 1990, p. 97]

Arthur Seldon writes, "Hayek argued that the cause of unemployment was not inadequate demand, arising from inadequate total income, but disproportions in relative wages required to equate the demand for labour and its supply in each sector of the economy." [Hayek (1976) 2009, Preface, p. 5] Arthur Seldon writes that Hayek thought, "The error of supposing that full employment, high output and prosperity could be maintained by enlarging total money expenditure is described ... as an age-old superstition to which Keynes and his followers have given the sanction of scientific authority." [Hayek (1976) 2009, Preface, p. 5] Hayek thinks, "Lord Keynes and his disciples have given to the age-old superstition that by increasing the aggregate of money expenditure we can lastingly ensure prosperity and full employment." [Hayek (1976) 2009, p. 9] Hayek argues, "just as there cannot be a uniform price for all kinds of labour, an equality of demand and supply for labour in general cannot be secured by managing aggregate demand. The volume of employment depends on the correspondence of demand and supply in each sector of the economy, and therefore on the wage structure and the distribution of demand between the sectors. The consequence is that over a longer period the Keynesian remedy does not cure unemployment but makes it worse." [Hayek (1976) 2009, p. 10]

Hayek wrote, "It may perhaps be pointed out that it has, of course, never been denied that employment can be rapidly increased, and a position of "full employment" achieved in the shortest possible time, by means of monetary expansion -least of all by those economists whose outlook has been influenced by the experience of a major inflation. All that has been contended is that the kind of full employment which can be created in this way is inherently unstable, and that to create employment by these means is to perpetuate fluctuations." [Hayek (1976) 2009, p. 11, Italics added] Hayek argues, "We cannot prevent substantial unemployment from re-appearing ... it is now bound to appear as a deeply regrettable but inescapable consequence of the mistaken policies of the past as soon as inflation ceases to accelerate." [Hayek (1976) 2009, p. 12]

Hayek argues, "This manufacture of unemployment by what are called 'full employment policies' is a complex process. In essence it operates by temporary changes in the distribution of demands, drawing 
both unemployed and already employed workers into jobs which will disappear with the end of inflation [increase in money-supply]" [Hayek (1976) 2009, p. 12] Hayek writes, "The pressure for more and cheaper money is an ever-present political force which monetary authorities have never been able to resist ... It was the main function of the gold standard, of balanced budget, of the necessity for deficit countries to contract their circulation, and of the limitation of the supply of 'international liquidity', to make it impossible for the monetary authorities to capitulate to the pressure for more money ... we cannot hope that any authority which has power to determine the quantity of money will long resist the pressure for, or the seduction of, cheap money." [Hayek (1976) 2009, p. 15] Hayek observed that, "Keynes could never free himself from the popular false belief that, as Law expressed it, 'as the additional money will give work to people who were idle and enable those already working to earn more, the output will increase and industry will prosper'." [Hayek (1976) 2009, p. 23] "If there are unemployed, says the progressive doctrine, the government must increase the amount of money in circulation until full employment is reached. It is, they say, a serious mistake to call inflation an increase in the quantity of money in circulation effected under these conditions. It is just "full-employment policy." [Mises 1953, p. 425]

Free currency System will dissuade the employers from wage-increasing that is a major cause of unemployment. Hayek wrote, "Make it [free currency system] merely legal and people will be very quick indeed to refuse to use the national currency once it depreciates noticeably, and they will make their dealings in a currency they trust. Employers, in particular, would find it in their interest to offer, in collective agreements, not wages anticipating a foreseen rise of prices but wages in a currency they trusted and could make the basis of rational calculation. This would deprive government of the power to counteract excessive wage increases, and the unemployment they would cause, by depreciating their currency. It would also prevent employers from conceding such wages in the expectation that the national monetary authority would bail them out, if they promised more than they could pay." [Hayek (1976) 2009, p. 19]

Mises argues that "In order to attain this result [reduction in unemployment] it would not have been necessary to embark upon increasing the amount of money in circulation. A reduction in the height of the minimum-wage rates enforced by the government or union pressure would have achieved the same effect without at the same time starting all the other consequences of inflation." [Mises 1953, p. 425, Italics added] "The full-employment argument in favor of inflation was already behind the times at the very moment when Keynes and his followers proclaimed it as the fundamental principle of progressive economic policies." [Mises 1953, p. 426] He observes, "inflationism is a self-defeating policy which must inevitably lead to an economic cataclysm and that all its allegedly beneficial effects are, even from the point of view of the authors of the inflationary policy, more undesirable than the evils which were to be cured by inflation". [Mises 1953, p. 426]

Henry Hazlitt opines, "Prolonged inflation never "stimulates" the economy. On the contrary, it unbalances, disrupts, and misdirects production and employment. Unemployment is mainly caused by excessive wage rates in some industries, brought about either by extortionate union demands, by minimum wage laws (which keep teenagers and unskilled out of job), or by prolonged and over-generous unemployment insurance.” [Hazlitt, Sept.1978] 


\section{Assessment of Austrian school's belief that increased money supply leads to unemployment and recession}

The Austrian economists argue that "just as there cannot be a uniform price for all kinds of labour, an equality of demand and supply for labour in general cannot be secured by managing aggregate demand. The volume of employment depends on the correspondence of demand and supply in each sector of the economy, and therefore on the wage structure and the distribution of demand between the sectors. The consequence is that over a longer period the Keynesian remedy does not cure unemployment but makes it worse." [Hayek (1976) 2009, p. 10] But they do not suggest any policy how "the correspondence of demand and supply in each sector of the economy" will be possible. They only suggest to deprive the government of its monopoly right over money-creation and to allow the people to create money of their own and to choose among various types of moneys. "I think if the capitalists had been allowed to provide themselves with the money which they need, the competitive system would have long overcome the major fluctuations in economic activity and the prolonged periods of depression." [Hayek April 2019, p.6] However, these measures (suggested by Austrian school) will not by itself achieve "the correspondence of demand and supply in each sector of the economy"

Hayek assertion, "If government did not increase the quantity of money such a rise in the wages of a group of workers would not lead to a rise in the general price level but simply to a reduction in sales and therefore to unemployment" [Hayek (1976) 1990, p. 95] is self-contradictory. Increase in the quantity of money by the government does not automatically leads to a rise in the wages. Government does not increase the quantity of money. Government gets money from the non-government sector through tax and borrowing and the non-government sectors gets that money back when government buys goods and services from the non-government sector. Besides, government does not just give away money to the industrial sector so that the industrial sector can increase the wages of its workers. Again, workers' wages does not influence the CPI; on the contrary, the increase in the CPI induces the labourers to demand hike in wages. Again, "reduction in sales" and reduction to unemployment cannot occur simultaneously; on the other hand, "reduction in sales" leads to increase in unemployment. Besides, increasing supply of money by the government means increasing purchase by the government. And, purchasing itself cannot "lead to a rise in the general price level" and/ or if it does, it must not be advisable to stop purchasing, because the purpose of economics activities is purchase and sale.

Mises argues that "In order to attain this result [reduction in unemployment] it would not have been necessary to embark upon increasing the amount of money in circulation. A reduction in the height of the minimum-wage rates enforced by the government or union pressure would have achieved the same effect without at the same time starting all the other consequences of inflation." [Mises 1953, p. 425] If we accept Mises advice, then in order to increase employment it would be necessary to reduce wages continuously till the wage is reduced to zero. Therefore, reducing wages cannot be the solution of unemployment problem.

The main defect of the Austrian school is that it does not suggest any alternative policy or ways how to reduce unemployment. It, rather, neglects the issue of unemployment. It only argues that, "We cannot prevent substantial unemployment from re-appearing." [Hayek (1976) 2009, p. 12] 


\subsection{The goal of the Austrian economists is not "Full Employment" but "creating value" or "creating wealth"}

Frank Shostak argues, "In truth, the main driver of economic growth is an expanding pool of real savings rather than the state of unemployment. Fixing unemployment without addressing the issue of real savings cannot lift the pace of economic growth as such." [Shostak 11 Aug. 2017] According to Mises, "The sine qua non of any lengthening of the process of production adopted is saving, i.e., an excess of current production over current consumption. Saving is the first step on the way toward improvement of material well-being and toward every further progress on this way." [Mises (1949) 1966, p.490] Following Mises, Frank Shostak also argues, "Real savings fund the enhancement and the expansion of the infrastructure. An enhanced and expanded infrastructure permits an expansion in the production of final goods and services required to maintain and promote individuals life and well-being."' [Shostak 11 Aug 2017]

Frank Shostak explains why targeting increase in employment will not lead to creation of real wealth or value. He writes, "If unemployment was the key driving force of economic growth then it would have made a lot of sense to eradicate unemployment as soon as possible by generating all sorts of employments. For instance, it would make sense to employ people in digging ditches, or various government sponsored activities. Again, the aim is just to employ as many people as possible.

We suggest that such a policy would amount to a waste of scarce real savings. Every activity, whether productive or non-productive, must be funded. Hence, employing individuals in various non-wealth generating activities would lead to a transfer of real savings from wealth generating activities and thereby undermine the real wealth generating process. " [Shostak 11 Aug. 2017, Italics added]

Frank Shostak argues that if government stays away from fixing minimum wage rate, free market will adjust all the unemployed to employment at the going market rate of wages. He writes, "Unemployment as such can be relatively easily fixed if the labor market were to be free of tampering by the government. In an unhampered labor market, any individual that wants to work will be able to find a job at a going wage for his particular skills. Obviously if an individual will demand, a non-market related salary and is not prepared to move to other locations there is no guarantee that he will find a job.

Over time, a free labor market makes sure that every individual earns in accordance to his contribution to the so-called overall "real pie." Any deviation from the value of his true contribution sets in motion corrective competitive forces." [Shostak 11 Aug. 2017, Italics added]

Frank shostak believes that -"The only credit that commercial banks can expand is credit out of "thin air," or "inflationary credit." He argues that if employment is created spending such "thin air" credit then "It must be realized that an increase in inflationary credit amounts to an increase in money supply "out of thin air" and hence to a diversion of real savings from wealth producers to non-wealth generating activities - obviously then the expansion in credit because of inflationary credit is bad news for economic growth. Hence, the currently observed decline in the growth rate of inflationary credit implies that the pace of the wealth diversion from wealth generators to non-wealth generators is slowing down.

Furthermore, if the pool of real savings is in trouble then it is quite likely that banks will curtail their credit expansion out of "thin air," which in turn will undermine the growth rate of the money supply." [Shostak 11 Aug. 2017, Italics added]

He argues, when banks begin to curtail creating "thin air" credit during boom phase, then "bubble activities" become bust and recession sets in. He writes, "A possible visible decline in the growth rate of AMS is going to undermine various non-productive i.e. bubble activities. If the percentage of these 
activities out of total activities is above 50\% this could result in a severe economic slump. Note that the slump is because of a likely demise of bubble activities. In this sense, this is good news for the economy since this will strengthen wealth generators and will lay the foundation for a genuine economic growth.

Also, note that the demise of bubble activities is going to be manifested by a sharp increase in the unemployment rate statistic. In this case, policy makers must stay out of the economy and let wealth generators to get on with the job of wealth generation. The build-up in real wealth coupled with a free labor market is going to absorb most unemployed individuals. " [Shostak 11 Aug. 2017, Italics added]

Frank Shostak argues that fighting unemployment with "thin air" credit will ultimately increases the possibility of "prolonged economic stagnation". He writes, "Policies aimed at "fighting" a high unemployment rate however, are likely to generate a further economic impoverishment and set in motion a prolonged economic stagnation." [Shostak 11 Aug. 2017]

Therefore, he suggests that creating employment spending "thin air" credit should be stopped and importance should be given on how "purchasing power" of the people can be increased. He writes, "We suggest that unemployment is not the key issue for economic growth. What matters for individuals is not whether they employed as such but the purchasing power of their earnings. The key for this is the infrastructure individuals utilize in the production of goods and services. What permits an increase of the production of goods and services and hence raises people's living standards is an expansion and the enhancement of infrastructure. What in turn permits this is an expanding pool of real savings. Contrary to popular thinking, the Fed's and the government policies that are aiming at lowering unemployment do not improve people's living standards, but on the contrary, they undermine the process of real wealth generation and thus set in motion an economic impoverishment." [Shostak 11 Aug. 2017, Italics added]

Fred Buzzeo writes, "The reality of high unemployment continues to plague the economy. Therefore, we must look elsewhere for solutions to the unemployment problem. We must ask, what is the correct path to sustained, noninflationary economic growth?" [Buzzeo 27 Dec. 2010] He argues that J. B. Say has shown how unemployment can be eradicated. He writes, "The essence of the argument [Say's Law] is that an increase in productive capacity will create employment and naturally increase the demand for products in general. Therefore, productive capacity is seen as the foundation for job creation and for the economic well-being that follows. Say's law had been the foundation of economic growth for decades." [Buzzeo 27 Dec. 2010]

Fred Buzzeo argues, "As Rothbard has demonstrated, if wages were allowed to drop during the Great Depression, we would not have seen unemployment rates of 25 percent. It is only when prices are not allowed to adjust in tandem that deflation becomes a problem. Such a scenario results when government interferes by keeping the price of commodities and labor high, as occurred in the Great Depression. The reason that politicians fail to allow prices to drop is to appease pressure groups — such as organized labor - that they are beholden to for votes and political contributions. Another reason is a lack of understanding concerning the quantity of money in a society." [Buzzeo 27 Dec. 2010]

Fred Buzzeo explains how employment can be increased. He writes, "What is the path to sustained, noninflationary economic growth - and hence to sustained job creation?

First, we must understand that artificial job creation by the government is not the answer. As the "Great Society" programs demonstrated, governments cannot produce noninflationary jobs. The reason for this is simple: governments do not produce goods. They do not add to the productive capacity of a nation. Government, through taxation and redistribution, destroys wealth. It does not create wealth. 
To create sustained, noninflationary employment, we must, as Jean-Baptiste Say told us 200 years ago, encourage production, not simply the consumption of goods. The Keynesian concept of stimulating aggregate demand is simply another economic myth. It runs counter to all sound economic policy. It is inflationary and does not lead to sustained economic growth.

In the words of John Stuart Mill, "What a country needs to make it rich is never consumption, but production. Where there is the latter, we may be sure that there is no want of the former." [Buzzeo 27 Dec. 2010, Italics added]

Fred Buzzeo also argues, "To expand productive activity and thus to create jobs, we must restore confidence in the system. As stated above, entrepreneurs do not invest freely in uncertain times or when they feel that their hard-earned profits will be confiscated in some redistribution-of-income scheme.

Confidence in the system can be restored by simple actions. The principal way is to leave decision making in the hands of the sovereign - the individual. The actions of the individual expressing his utility in the marketplace will determine the correct level of investment, production, and consumption. That is the only foolproof way to achieve a noninflationary economic expansion with healthy job growth." [Buzzeo 27 Dec. 2010, Italics added]

According to Anne Bradley, "It's easy to believe that we can support a government job creation program to solve the real need for jobs. However, these jobs come at a cost and often put an overwhelming burden on the private sector. This actually costs us future jobs and opportunities" because "The government is not a business that sells things. It only "produces" or provides goods and services by generating revenue, often through taxation and currency inflation. This imposes a tradeoff, or the cost of other foregone opportunities." "This is not because government jobs are filled with bad or lazy people, but because the government does not operate under the strict discipline that the profit and loss mechanism enforces. Christians must strive to create value for others through their work and do their job well." [Bradley 11 Sept. 2013]

Dwight R. Lee also argues in the same vein. He writes, "The jobs created by a government project represent a cost of the project: the opportunity cost. The workers employed in government activities could be producing value doing something else. The relevant question is not whether a government project creates jobs, but whether the workers in those jobs will create more wealth than they would in other jobs. This is a question advocates of government programs don't want asked. If it were, there would be far fewer low-productivity government jobs and far more high-productivity private-sector jobs." [Dwight R. Lee 10 Jan 2000]

Dwight R. Lee argues that "Creating Jobs Is Not the Problem ... There will always be jobs to do far more than can ever be done. So creating jobs is not the problem. The problem is creating jobs in which people produce the most value." [Dwight R. Lee 10 Jan 2000]

Bradley argues, "Markets bring jobs, new specialties, and fields of expertise that didn't exist even a century ago. Jobs created through market competition are much more likely than government jobs to foster entrepreneurial thinking, discoveries, and the products and services which make people's lives better at increasingly lower costs." Therefore, Bradley suggests that "Our focus needs to be on wealth creation and flourishing, not just job creation." [Bradley 11 Sept. 2013]

Anne Bradley argues, "there is a significant difference between creating value, which leads to wealth accumulation, and creating jobs, which may actually destroy wealth and create dependencies." [Bradley 11 Sept 2013] 
Jonny writes, "Henry Hazlitt correctly identifies: "The real question is not how many millions of jobs there will be in America ten years from now, but how much shall we produce, and what, in consequence, will be our standard of living?" [Jonny 08 Oct. 2012] Austrian economists argue that "creating jobs is easy" but we should aim at creating value (or wealth) to enhance our standard of living. Steven Horwitz writes, "More important, though, is that both Krugman and politicians from both parties are much too concerned about job creation when they should be concerned about value creation. Creating jobs is easy; it's creating value that's hard. We could create millions of jobs quite easily by destroying every piece of machinery on U.S. farms. The question is whether we are actually better off by creating those jobs - and the answer is a definite no. We want labor-saving, job-destroying technology because it creates value by enabling us to produce things at lower cost and thereby free up labor for more urgent uses." [Steven Horwitz 2012 April 26] Dwight writes, "All economic progress results from being able to provide the same, or improved, goods and services with fewer workers, thus eliminating some jobs and freeing up labor to increase production in new, more productive jobs." [Dwight R. Lee 10 Jan 2000]

Therefore, Horwitz writes, "Even if a value-creating innovation destroys jobs in the short run, the increased wealth will bring a great deal of job creation in its wake. So rather than talking about job creation, let's focus on value creation. The case for freeing markets is that such freedom best enables individuals to find ways to use their knowledge and skills to create value for others and thereby create wealth for themselves. The more wealth that value creators can keep, the more likely they are to continue to create it. Even if a value-creating innovation destroys jobs in the short run, the increased wealth will bring a great deal of job creation in its wake." He also argues, "The next time anyone starts talking about job creation, stop listening. Jobs come into existence when entrepreneurs are free to create value. Aiming directly at job creation is a recipe for waste and poverty. Set people free to use their talents to create value for others and the jobs will follow." [Horwitz 26 April 2012]

\section{Assessment of the goal of the Austrian economists is not "Full Employment" but "creating value" or "creating wealth"}

The Austrian school does not want to solve the unemployment problem because they think that full employment will retard the process of wealth (value) creation and thus will hamper economic growth. Therefore they argue that, "“'Our focus needs to be on wealth creation and flourishing, not just job creation."

They argue that in the desire to give employment to all, the government employs people in some insignificant works that may lead to wastage of resources rather than creating any wealth. They write, "it would make sense to employ people in digging ditches", and "employing individuals in [such] various non-wealth generating activities would lead to a transfer of real savings from wealth generating activities and thereby undermine the real wealth generating process."

However, this belief of Austrian school is altogether wrong. The activities for which the government spends are public works like roadways, airways, waterways, telecommunications, administrative buildings, military bases, hospitals, schools etc. that are used by the public for their own benefit. Besides, government spends for public utility services like defense, maintenance of law and order, justice, education, health and sanitation etc. Therefore, government expenditure is neither waste nor 'a transfer of real savings from wealth generating activities'. The works and services created and rendered by the government are 'real wealth' and not 'non-wealth'.

Austrian school suffers from contradictions in respect of what the government really spends for. Once they argue that, "governments do not produce goods. They do not add to the productive capacity of a 
nation. Government, through taxation and redistribution, destroys wealth. It does not create wealth." In another time they argue that, "It [the government] only "produces" or provides goods and services by generating revenue, often through taxation and currency inflation." Here the contradiction is that once they tell "government does not produce goods", another time they tell "It [the government] only "produces" or provides goods and services".

But, in both cases, they argue that taxation is bad. However, what the government really does is that government sells goods and services to the public against the payment of tax. The Austrian economists want just the same thing i.e. selling or buying something for something (and not something for nothing) that they think will lead to economic growth. Government does not destroy money (wealth) because government does not just give away money to anybody. It spends money for buying something and buying something is not wasteful "redistribution". Government does not generate "currency inflation". Government can spend only that money that it gets either as tax-payment to itself or as borrowing through bond-sells. As government cannot create money, it does not add any extra money that may increase the aggregate quantity of money-supply to the economy.

Austrian economists are of the view that if wages were not allowed to rise to adjust the increasing demand by the workers to raise wages and if unemployed were left to accept jobs at the floor rate of wages, then there would be no dearth of employment. They write, "Obviously if an individual will demand, a non-market related salary and is not prepared to move to other locations there is no guarantee that he will find a job." Again Rothbard writes, "if wages were allowed to drop during the Great Depression, we would not have seen unemployment rates of 25 percent."

However, this idea that if there were no lower limit of wages, every people will find a job at the floor rate of wages is not correct. Even at the floor rate of wages total number of demand for labors (workers) always lag behind the total number of unemployed. Private sector will not employ more workers than what they need to run their business; they will also not employ more workers that will cost their profits to zero or negative. Only government can create employment in various public works and services that will improve the aggregate living standard of the whole nation.

The Austrian economists also want to enhance the living standard of the people. For creating more employment it is not at all necessary to change from technology-intensive production to labor-intensive production as they argue, "We could create millions of jobs quite easily by destroying every piece of machinery on U.S. farms. The question is whether we are actually better off by creating those jobs-and the answer is a definite no." There always remains more works and services to be done to improve the wellbeing and thus achieve economic growth. They themselves write, "“"Creating Jobs Is Not the Problem ... There will always be jobs to do far more than can ever be done. So creating jobs is not the problem". If "there will always be jobs", then why unemployed will not be employed to those jobs. It is silly to think that those jobs will not produce "the most value". Their argument in favor of not giving those jobs to the unemployed is "The problem is creating jobs in which people produce the most value" and "Creating jobs is easy; it's creating value that's hard." It is a lame excuse. If there remains some works to be done, then those works have some value, if not "the most value". If those works are done, then some wealth, whatever may be their qualitative degree of being wealth will be added to the aggregate wealth of a nation. Again, this will increase the living standard and will help workers to earn some money with which they can buy their necessities. There are works to be done and there are unemployed to do those works. It 
would be unwise to leave the "jobs to do far more than can ever be done" on the excuse that they will not create "the most value" and leave some people unemployed who need employment just to maintain their physical existence.

Austrian school thinks that increase in production leads to increase in employment and thus unemployment can be eradicated. Supporting J. B. Say, they argue "“"The essence of the argument [Say's Law] is that an increase in productive capacity will create employment and naturally increase the demand for products in general. Therefore, productive capacity is seen as the foundation for job creation and for the economic well-being that follows. Say's law had been the foundation of economic growth for decades.” [Fred Buzzeo 27 Dec. 2010]

However, this argument is also wrong. Increase in production will not create employment; it will reduce employment because technology helps to produce more than what the labor can produce without using technology. And the Austrian economists favor labour-saving technology. They write, "We want laborsaving, job-destroying technology because it creates value by enabling us to produce things at lower cost and thereby free up labor for more urgent uses." [Horwitz 26 April 2012] Therefore, it is wrong to argue that an "increase in production capacity will create employment."

However, Austrian economists give priority to value (wealth) creation than to reduce unemployment. They suffer contradictions in their belief that if they "focus on value creation" then "job creation" will ultimately follow the "value creation". Dwight writes, "All economic progress results from being able to provide the same, or improved, goods and services with fewer workers, thus eliminating some jobs and freeing up labor to increase production in new, more productive jobs" and "Aiming directly at job creation is a recipe for waste and poverty. Set people free to use their talents to create value for others and the jobs will follow." However, it becomes unintelligible how "the jobs will follow" if "job creation is a recipe for waste and poverty" and if "value-creating innovation destroys jobs", and if "eliminating some jobs and freeing up labour [is] to increase production in new, more productive jobs".

"Full Employment is not the Goal" [Jonny, 08 Oct 2012] of the Austrian School of Economists. They think that "Employment Is Not the Key to Economic Growth" [Shostak, Aug 2017]

2. 25. It is ambiguous whether the Austrian economists wanted to put an end to the credit creation by the commercial banks or to the fiat money creation by the money-issuing private banks or to the increase in any type of money including the commodity-money.

Mises wrote, ““'As I have explained [in The Theory of Money and Credit], there is a serious danger for the future of the individualistic organization of the economy in the development of fiduciary media; if the legislature does not put some obstacle in the way of its expansion, an unrestrained inflation could easily come about, the destructive effects of which cannot really be imagined. Even if we ignore this, as yet, not immediate threat, there is sufficient risk from the very nature of the system of fiduciary media.... it would be desirable to put an end to the artificial expansion of fiduciary media. It would not only slow down the rate of devaluation [price inflation], but it would also be the best way of preventing economic crises." [Mises, "The General Rise in Prices in the Light of Economic Theory," In Selected Writings of Ludwig von Mises, Vol. 1, 131-55 (Indianapolis: Liberty Fund, 2012), p. 155] [Quoted in Fuller, June 2019, p. 1]

However, the Austrians have used the terms "fiduciary media" and "fractional reserve banking" interchangeably in their writings. Fuller writes, ““'Mises makes three significant points ... First, Mises 
considered fractional reserve banking a serious danger to capitalism. ... Second, Mises thought the "legislature" should "put an end" to fractional reserve banking. ... Third, he notes that putting an end to fractional reserve banking will prevent the business cycle." [Fuller 2019, p 1] "Mises thought fractional reserve banking per se would set in motion the business cycle." [Murphy June 2019, p. 9] "Mises and Hayek both believed that fractional reserve banking per se is instrumental to the business cycle." [Murphy June 2019, p. 5]

However, Mises himself is not sure whether he wants to put an end to only "fiduciary media" (interchangeably "fractional reserve banking") or to any type of increase of money including the commodity money. Mises writes, "Everything that has been asserted with regard to credit expansion is equally valid with regard to the effects of any increase in the supply of money proper as far as this additional supply reaches the loan market at an early stage of its inflow into the market system." [Mises (1949) 1998, pp. 571-72] Murphy writes, "we can summarize Mises's position as follows: The unsustainable boom occurs when a newly created (or mined) quantity of money enters the loan market and distorts interest rates, before other prices in the economy have had time to adjust. In principle, this process could occur even in the case of commodity money with 100 percent reserve banking." [Murphy June 2019, p. 8]

There is a debate among the followers of Mises-Hayek regarding whether Mises favored "fractional reserve free banking" (FRFB) or favored 100\% reserve banking. However, the followers of Mises-Hayek are confused in understanding "fractional reserve banking" (interchangeably "fiduciary media"). Hulsmann writes, "This debate does not relate to problems of money production and currency, but refers more narrowly to the production of money titles by financial service providers such as commercial banks. [Hulsmann 2000, p. 102] On the contrary, "critics of fractional reserve banking claim that, under a gold standard, any issue of bank-created exchange media unbacked by gold ("fiduciary media") will fuel the business cycle." [Selgin 2000, p. 94]

Debate over whether Mises favored "the production of money titles by financial service providers such as commercial banks." "This debate concerns whether commercial banks ought to be allowed to continue their commonplace practice of generating redeemable IOUs, including checkable bank deposits and (less commonly nowadays) circulating bank notes, in amounts exceeding their available reserves of standard money." [Selgin 2000, p. 93]

\section{However, Austrian economists are confused whether commercial bank must follow Cash Reserve Ratio (CRR) rules when they issue loans and create deposit in the borrowers' account.}

Robert P. Murphy explains that "fractional reserve banking" is subject to CRR rule. He writes, "banks in the United States are subject only to a reserve requirement of (approximately) 10 percent, [if some customer named Bill deposits \$ 1000 in a bank and the bank deposits $10 \%$ of \$ 1000 in its account in the central bank] the bank would have new excess reserves of $\$ 900$. If it found a suitable borrower, the bank would have the legal ability to grant a new loan for this amount. Suppose the bank found such a borrower, Sally". [Murphy June 2010, p. 1] "the bank created $\$ 900$ in new money ... and then destroyed the $\$ 900$ when Sally paid back her loan.” [Murphy June 2010, p. 3]

The "bankers who engage in fractional-reserve banking really do "create money out of thin air"'[Murphy June 2010, p. 1] Horwitz writes, "Banks serve as intermediaries to redirect savings to investors via money creation. Depositors give banks custody of their funds, and banks create loans based on these deposits. The creation (supply) of money corresponds to a supply of funds for investment use by firms." [Horwitz 1992, 135, quoted in Murphy June 2019, p. 11] "Some people deny that commercial banks "create 
money out of thin air." They agree that the Fed does so when it buys assets by writing a check on itself. However, in our example above, it seems that the commercial bank at worst is taking $\$ 900$ of "Bill's money" and handing it over to Sally." [Murphy June 2010, p. 3]

Murphy even suggested that banks can create more in the following way. "Consider: The bank received $\$ 1,000$ in currency from Bill, and it then made a loan of $\$ 9,000$ to Sally. This new money didn't "come from" anywhere; it existed as soon as the bank clerk changed the numbers on the ledger. Sally went from having $\$ 0$ in her checking account to having $\$ 9,000$, with the simple push of a button." [Murphy June 2010, p. 4]

Jorg Guido Hulsmann explains the process of fractional reserve banking by commercial banks without being subjected to CRR rule. He writes, "Banks engage in fractional reserve banking when they use deposited money to grant credits. They do so either by lending out deposited money directly or by producing money titles in excess of the money they have in their vaults. For example, the customers of the FR Bank (FRB) have deposited \$1,000, and the FRB has issued corresponding statements of account. Now the bank grants a $\$ 500$ credit to Johnson in the form of a newly "created" bank account with a $\$ 500$ balance. This action immediately creates a situation in which contradictory claims to physical dollar bills exist. The depositors have present claims to $\$ 1,000$ because they did not renounce their title to the full amount of their deposits. But Johnson has a present claim to another $\$ 500$. Clearly, it is impossible for all these claims to be satisfied with the existing quantity of dollars in the vaults of the bank." [Hulsmann 2000, p. 103] "On the economic level, it implies right now a disequilibrium, because the depositors act as if they controlled the full amount of their deposits, and Johnson acts as if he controlled another $\$ 500$. The members of our little community thus behave as if they could rely on more resources than really do exist. In short, they have fallen prey to an illusion. The illusion can persist for a while because of the following circumstance: the depositors rarely redeem all of their titles." [Hulsmann 2000, pp. 103-104] "The main problem of fractional reserve banks is, of course, that they are virtually bankrupt, because at any point of time they have more cash liabilities than they have cash in their vaults. If too many customers demand redemption of their titles, the bank is doomed. ... Clearly, this endeavor enhances the likelihood that one day it will be left with less than sufficient cash to redeem the titles it has issued. Moreover, the failure of one fractional reserve bank can trigger the failure of many other fractional reserve banks through a domino effect. Many banking crises in the past have indeed featured a domino effect, which resulted eventually in the breakdown of the entire banking system." [Hulsmann 2000, p. 105] "the creation of additional fiduciary titles reduces the purchasing power of money ... as soon as those titles are issued, people start acting in incompatible ways. This reaction is precisely what is at the heart of the state of affairs that economists call disequilibrium." [Hulsmann 2000, p. 107] Though the depositors know how much credit they have in their banks, yet they do not know whether the banks have that amount of money in the banks' reserve. Hulsmann writes, "However, although it is usually clear who owns which title, it is not at all clear who owns the money to which these titles fiduciary money] refer. There are more titles than money. Here lies the contradiction. Here is the root of the disequilibrium entailed by fractional reserve banking." [Hulsmann 2000, p. 107] "By its very nature, fractional reserve banking brings about a difference between what exists and what people think exists. It makes people think that they are better off than they really are-and that conviction sets in motion the boom phase of the business cycle. Yet sooner or later comes the bust, when they discover that in their ventures they relied on things that do not exist." [Hulsmann 2000, p. 108] 
According to Hulsmann, "they [the initial depositor to the bank and the subsequent borrowers from the bank] have fallen prey to an illusion [that all of them can use the money they have in their account, whereas, only the sum of money that is deposited initially, and not the aggregate sum in accounts of all the depositors, is available for use]". [Hulsmann 2000, p. 103] "Clearly it is impossible for all these claims to be satisfied with the existing quantity of dollars in the vaults of the bank." [Hulsmann 2000, p. 103] "The illusion can persist for a while because of the following circumstance: the depositors rarely redeem their titles." Here, Husmann clearly states that all of the depositors cannot use their account at the same time. On the contrary, he writes, "Fractional reserve banking is nothing but a large-scale Ponzi scheme. It enriches some at the expense of others. It brings about economic disruptions and serves as the handmaiden of governments and other vested interests." [Hulsmann 2000, p. 108] If according to him, only initially deposited sum can be used, how that money "brings about economic disruptions" [Hulsmann 2000, p. 108], because no more than only the initially deposited money is available for use whether the initial sum is increased or not through fractional reserve banking. Therefore, this logic that fractional reserve banking "brings about economic disruptions" is wrong.

\section{Austrian economists are divided in two groups over the issue of rejecting or favoring fractional reserve banking}

\section{Arguments of the Austrian economists who rejected fractional reserve banking by commercial banks:}

"For a long time, the standard Austrian view rejected fractional reserve banking. From the publication of his Theory of Money and Credit in 1912, Ludwig von Mises $(1980,1998)$ rejected fractional reserve banking for economic reasons. So did F. A. Hayek $(1929,1931,1937)$, at least in his early monetary writings. Murray Rothbard (1983, 1990, 1991, 1993, 1994) rejected it on both economic and ethical grounds." [Hulsmann 2000, p. 104] Mises argued that creation of credit by commercial banks must be done away with. In an essay titled "The Return to Sound Money" in his The Theory of Money and Credit [1912] 2009, Mises argued, "No bank must be permitted to expand the total amount of its deposits subject to cheque or the balance of such deposits of any individual customer... otherwise than by receiving cash deposits in legal tender bank-notes from the public or by receiving a cheque payable by another domestic bank subject to the same limitations. This means a rigid 100 per cent reserve for all future deposits, i.e. all deposits not already in existence on the first day of reform." [Mises [1912] 2009, p. 448, qtd. in Murphy June 2019, p. 17] "Removing government's monopoly on issuing legal tender would not only provide us with stable money, it would also do away with those credit pyramids in particular countries where a fractional reserve system makes it equally impossible for the central bank and the commercial bank to exercise effective control over the quantity of all money of a particular denomination." [Hayek Oct 2014]

\section{Arguments of the Austrian economists who favor fractional reserve banking by commercial banks:}

"Mises originally conceded some advantages to fractional reserve banking, but he later repudiated that concession. On balance he was always an outspoken opponent of it." [Hulsmann 2000, p. 104] Following this concession of "some advantages to fractional reserve banking", some Austrian economists deviated from the orthodox view against "fractional reserve banking". "Deviation from this orthodoxy was led by Lawrence H. White in his 1984 book Free Banking in Britain and in later books (1989, 1999). White's case for fractional reserve banking was extended and systematized by his student George Selgin (1988) in The Theory of Free Banking, as well as in a later collection of articles (1996). Several other authors joined their ranks but did not exercise as much influence. Apart from Rothbard (1988) and Walter Block (1988), hardly anybody's writings defended the orthodox position in the late 1980s and early 1990s. Thus, the case for fractional reserve free banking was on the verge of becoming a tenet of the Austrian mainstream, 
at least as far as published work was concerned. It was this very success of White and Selgin that aroused interest in their work and led other scholars to critically examine their arguments." [Hulsmann 2000, p. 104]

Murphy states that no legal provision can prevent commercial banks from making new loans. "Sure, that "commercial banks "create money out of thin air" [Murphy June 2010, p. 3] might be dubious, but it's not as blatant as when the Fed literally writes checks drawn on thin air, right? Actually, I think this standard textbook description - in which each new bank in the sequence creates new loans equal to 90 percent of the new deposit - is a bit misleading. There is nothing in the legal reserve requirement to prevent banks from making new loans that are large multiples of a new deposit." [Murphy June 2010, p. 3] Hulsmann does not want to outlaw the "fractional reserve banking". He argues, "Should fractional reserve banking be outlawed if all parties concerned know what they are doing? No, it should not be, because no law should suppress any foolish activity just because it is foolish." [Hulsmann 2000, p. 108]

\section{Debate over whether Mises favored the creation of fiat money or not}

"Because Austrian- School economists generally favor a gold standard over an irredeemable paper or "fiat" standard, the debate can be framed as one between defenders of fractional gold bank reserves on one hand and their critics who favor one hundred percent gold reserves (so that all bank-issued exchange media are fully backed by gold) on the other. I [Selgin], together with Lawrence H. White, have been among the defenders of fractional reserve banking (see Selgin and White 1996), whereas Hans-Hermann Hoppe (1998) and the late Murray Rothbard (1962) have been two of the more prominent advocates of one hundred percent reserves." [Selgin, 2000, p. 93] On the one side of the debate, there are economists who are against Fractional Reserve Free Banking (FRFB); on the other side are those who support FRFB.

"Both sides in this debate have devoted much effort to determining whether the great Austrian economist Ludwig von Mises himself favored fractional reserve banking. The truth seems to be that Mises saw both advantages and disadvantages to the arrangement, so that both sides have been able to quote him in their favor. Perhaps Mises's views on this subject changed over time.” [Selgin 2000, p. 94]

\section{Arguments of the Austrian Economists who rejected FRFB (Fiat Money)}

"The critics of fractional reserve banking condemn it for at least three reasons. First, they claim that the practice is practically or even inherently fraudulent ... According to this view, fractional reserve banking has survived up to the present only because of bankers' dishonesty and (in more recent decades) government-mandated deposit insurance.

Second, critics of fractional reserve banking claim that, under a gold standard, any issue of bank-created exchange media unbacked by gold ("fiduciary media") will fuel the business cycle. They maintain that bank loans funded by outstanding bank notes and demand deposits are ultimately financed by "forced" savings: in issuing spendable IOUs to borrowers, banks reduce interest rates below their "natural" levels, promoting investment at the expense of other producers and consumers who find themselves bidding against bank borrowers for scarce resources. Eventually this bidding war will force up prices and interest rates, restoring the purchasing power of the money stock to its pre-expansion value. But by that time, resources will already have been improperly invested in projects that are not sustainable given the amount of voluntary (as opposed to forced) savings available from the public. The collapse of unsustainable projects, followed by the consequent restoration of a pattern of resource use something like the pattern that preceded the issue of fiduciary media, marks the bust and recovery stages of the business cycle. 
Third, fractional reserve banking systems are said to be fragile and vulnerable to collapse whenever their customers lose confidence in them. Because no fractional reserve bank, no matter how well managed, can afford to pay off all its IOU holders at once should they simultaneously demand their money back, each bank faces a positive probability of catastrophic failure at any moment." [Selgin 2000, p. 94, Italics added]

"FRB necessarily leads to an unsustainable boom as described first by Mises ([1912] 2009) and elaborated by his disciple Hayek (e.g. [1931] 1967). It is significant that both of these developers of what is sometimes called "the Mises-Hayek theory of the business cycle" thought that FRB was a central element of the story." [Murphy June 2019, p. 5]

Mises "is contrasting it ["credit expansion"] with "an increase in the supply of money proper". [Murphy June 2019, p. 8] "The only vehicle of credit expansion is circulation credit [fiat money]. But the granting of circulation credit does not always mean credit expansion. If the amount of fiduciary media previously issued has consummated all its effects upon the market, if prices, wage rates, and interest rates have been adjusted to the total supply of money proper plus fiduciary media (supply of money in the broader sense), granting of circulation credit without a further increase in the quantity of fiduciary media is no longer credit expansion. Credit expansion is present only if credit is granted by the issue of an additional amount of fiduciary media, not if banks lend anew fiduciary media paid back to them by the old debtors." (Mises [1949] 1998, p. 431) [Quoted in Murphy June 2019, p. 8, Italics added]

Fuller writes, "Economists debate whether Ludwig von Mises advocated free banking or 100 percent reserve banking. This debate is significant. Mises states, "the institution of credit expansion ... may be called the most important economic problem of our age." Given this statement, he must have viewed the solution to the problem as an extremely serious matter. Free bankers insist that Mises's solution was free banking. In reality, Mises advocated 100 percent reserve banking." [Fuller June 2019, p. 1]

"On June 14, 1912, Mises published his seminal work The Theory of Money and Credit. In that book, Mises shows that fractional reserve banking has four fundamental economic consequences: 1 . Fractional reserve banking causes price inflation, 2. Fractional reserve banking causes wealth redistribution, 3 . Fractional reserve banking is the cause of systemic banking panics, [and] 4. Fractional reserve banking is the cause of the business cycle. Mises advocates the legal prohibition of fractional reserve banking in The Theory of Money and Credit." [Fuller June 2019, p. 1]

\section{Another group of Austrian economists who favor FRFB (Fiat Money) argue}

Murphy writes, "We find an unambiguous statement of Mises's position in Human Action. Mises defines "fiduciary media" as bank-issued claims to money, payable upon demand, that are not covered by base money in the vault, and then declares:

"The notion of "normal" credit expansion is absurd. Issuance of additional fiduciary media, no matter what its quantity may be, always sets in motion those changes in the price structure the description of which is the task of the theory of the trade cycle. Of course, if the additional amount issued is not large, neither are the inevitable effects of the expansion. (Mises [1949] 1998, 439, n. 17] Quoted in Murphy June 2019, pp. 5-6, Italics added]

From this ambiguity of Mises regarding effects of additional issue of fiat money, the supporters of FRFB inspired to argue that fractional reserve bank is not the problem. "The free bankers [supporters of "fractional reserve free banking" (FRFB) like Selgin (1988), Selgin and White (1996), and Horwitz (2001)] endorse the Mises-Hayek theory of business cycles, but they deny that fractional reserve banking 
per se is the problem. Instead, the advocates of FRFB blame various types of government interference with money and banking." [Murphy June 2019, p. 4]

"In a free market with no central bank or government-provided deposit insurance, profit-maximizing commercial banks will - so the free bankers claim - only issue fiduciary media in the case when the public increases its demand to hold bank money, and this is precisely the scenario in which we should want them to do so. The free bankers argue that an insistence on 100 percent bank reserves in the face of a sudden increase in the public's demand to hold bank-issued money will lead to a period of monetary disequilibrium (in the sense of Yeager 1997).” [Murphy June 2019, p. 9]

Selgin and White argue: "We aspire to be consistent Wicksellians, and so regard both price inflation and deflation as regrettable processes insofar as they are brought about by arbitrary changes in the nominal quantity of money, or by uncompensated changes in its velocity, and not by changes in the real availability of final goods or the cost of production of money. It is therefore an attractive feature of free banking with fractional reserves that the nominal quantity of bank-issued money tends to adjust so as to offset changes in the velocity of money. Free banking thus works against short-run monetary disequilibrium and its business cycle consequences." [Selgin and White 1996, 101-02] [Quoted in Murphy June 2019, p. 9]

Selgin writes, "When a change in the demand for (inside) money warrants a change in its supply (in order to prevent excess demand or excess supply in the short run), the adjustment must occur by means of a change in the amount of funds lent by the banking system." [Selgin 1988, 54-55] [Quoted in Murphy June 2019, p. 10]

Supporters of FRFB argue that if to maintain "monetary equilibrium" private banks issue money through fractional reserve banking, then that should be treated as "warranted" and not as "arbitrary changes in nominal quantity of money". [Slgin and White 1996, 101-102]

Selgin argues, “... redeemable banknotes and deposit credits are not "titles," as Hoppe and his co-authors claim. They are instead IOUs, so there is nothing inherently fraudulent about there being more of them in existence at any moment than the total stock of what they promise to deliver. (If all IOUs had to represent existing property in order to be nonfraudulent, most loan transactions would be fraudulent.)" [Selgin 2000, p. 96]

Favoring increase in supply of fiat money (fractional reserve free banking) Selgin writes, "In truth, whether an addition to the money stock will aggravate the business cycle depends entirely on whether or not the addition is warranted by a preexisting increase in the public's demand for money balances. If an expansion of the supply of bank money creates an overall excess of money, people will spend the excess. Borrowers' increased spending will, in other words, not be offset by any corresponding decline in spending by other persons. The resulting stimulus to the overall level of demand for goods, services, and factors of production, together with changes in the pattern of spending prompted by an artificial lowering of interest rates, will have the adverse business-cycle consequences described by the Austrian theory.

But no such consequences follow an expansion of the stock of bank money that merely accommodates a prior increase in the demand for money holdings. Such an expansion, instead of adding to the flow of spending, merely keeps that flow from shrinking, thereby sustaining normal profits for the "average" firm. The expansion therefore serves not to trigger a boom but to avoid a bust. As far as business-cycle consequences are concerned, it makes no difference whether the new money is or is not backed by gold. The extent of gold backing does matter as far as the liquidity of the banking system is concerned." [Selgin 2000, p. 97, Italics added] 
Selgin argues, "The question then is, can the very limited financial wealth embodied in the nation's money holdings be used to fund productive investments that will eventually rescue the society from poverty? If money consists of gold coin alone or of bank-issued IOUs fully backed by gold, the answer is no: the nations' scarce savings will be invested in an accumulation of gold, and that's all. If, on the other hand, money consists of bank-issued IOUs backed mainly by bank loans, then its citizens' scarce savings will contribute toward a general process of industrialization, with investments made where (riskadjusted) rates of return appear greatest. According to many scholars, including Adam Smith, the industrialization of the West and of developed countries elsewhere was crucially dependent on funds mobilized by fractional reserve banks." [Selgin 2000, p. 99, Italics added] Selgin concluded, "Given a choice, most people prefer to let their banks create money only fractionally backed by cash reserves. And they are not fools for doing so." [Selgin 2000, p. 99]

\section{The debate over whether increase in commodity money ("money proper") affects price-inflation and causes business cycle}

Once, Mises argue that expansion of commodity money causes unsustainable boom-bust cycle. "We can summarize Mises's position as follows: The unsustainable boom occurs when a newly created (or mined) quantity of money enters the loan market and distorts interest rates, before other prices in the economy have had time to adjust. In principle, this process could occur even in the case of commodity money with 100 percent reserve banking." [Murphy June 2019, p. 8] "in principle Mises's theory of the boom-bust cycle is fundamentally about new quantities of money hitting the loan market early on." [Murphy June 2019, p. 8]

Another time, Mises argue that if the expansion of money is $100 \%$ backed by gold (commodity) then it will not have inflationary impact on the economy. Actually, he [Mises] argues 100 percent banking is the only viable solution: "It is illusory to expect that any method other than the one hundred percent reserve plan could possibly work under postwar conditions." [Mises, "A Noninflationary Proposal for Postwar Monetary Reconstruction," In Selected Writings of Ludwig von Mises, Vol. 3, 71-118 (Indianapolis: Liberty Fund, 2000), p. 108] [Quoted in Fuller June 2019, P 2] Because, "In particular, metals such as gold and silver can be produced on purely free-market terms, that is, without requiring any form of legal privilege, and their quantities depend far less on any human being's arbitrary whims. No special reform measures are required to set up a metallic currency system, because gold and silver coins are likely to emerge spontaneously on a truly free market." [Hulsmann 2000, p. 101] Therefore, "It is important to realize that commodity credit cannot be expanded." [Mises (1949) 1998, 431] [Quoted in Murphy June 2019, p. 8] Besides, "The gold standard was an efficacious check upon credit expansion, as it forced the banks not to exceed certain limits in their expansionist ventures. The gold standard's own inflationary potentialities were kept within limits by the vicissitudes of gold mining." [Mises (1949) 1998, 571-72] [Quoted in Murphy June 2019, p. 7] "Thus, even though in principle Mises's theory of the boom-bust cycle is fundamentally about new quantities of money hitting the loan market early on, in practice the explanation revolves around newly-created fiduciary media being lent into the market. That is why Mises described his explanation as the "circulation credit theory of the trade cycle."" [Murphy June 2019, p. 8]

However, what Mises possibly intended to argue is that the expansion of fiduciary media (both the fiat money created by issuing banks and the credits created by commercial banks) causes more harm to the economy than the expansion of commodity money can do. Mises argues, "Even a rapid increase in the production of the precious metals can never have the range which credit expansion can attain. ... Moreover, only a part of the additional gold immediately increased the supply offered on the loan market. The greater part acted first upon commodity prices and wage rates and affected the loan market only at a later stage of the inflationary process." [Mises (1949) 1998, 571-72] [Quoted in Murphy June 2019, p. 7] 
Another group of Austrian economists place contradictory arguments regarding whether expansion of new commodity money is necessary to adjust the increasing demand for money. Once, they argue that "Increase in the demand for money offset themselves." [Hulsmann 2000, p. 107] "the supply of money does not have to be adjusted to the demand for money. Unlike all other commodities, money itself constantly adjusts to the conditions of the market. The services rendered by any unit of money are constantly adjusted under the impact of changes in the demand for and supply of money. Of course, this self-adjustment does not work out to everybody's benefit. No adjustment does, and no institutional arrangement such as fractional reserve banking can change this fact." [Hulsmann 2000, p. 106] Because, expansion of commodity money like fiduciary (fiat) money reduces the purchasing power of money. Hulsmann writes, "the creation of additional fiduciary titles reduces the purchasing power of money - an effect shared with increases in the supply of money proper." [Hulsmann 2000, p. 107] Another time, they argue that the expansion of commodity money will not affect the economy in any way. Hulsmann writes, "An increase in the supply of money proper does not entail a disequilibrium, because the market participants can anticipate the impact that this additional quantity of money will have on prices and because it is usually clear who owns each single money unit." [Hulsmann 2000, p. 107] "Strictly speaking, this statement holds true only for commodity money, not for fiat money." [Hulsmann 2000, p. 107]

Though the Orthodox economists and the supporters of FRFB are divided on the issue whether any increase in supply of money (commodity-money and fiat money issued by the central bank and the creditmoney created by the commercial banks) has any adverse effect on the economy, both these two groups are unanimous on the issue that government interference with the money and banking is responsible for economic instability and ultimately for boom-bust cycle. They "blame various types of government interference with money and banking " [Murphy June 2019, p. 4] Both these two groups argue that the central bank and the government arbitrarily reduce the interest rates to inject more money into the economy that causes prices of money to fall and disequilibrium in the economy. Therefore, "The most important prerequisite of any cyclical policy, no matter how modest its goal may be, is to renounce every attempt to reduce the interest rate, by means of banking policy, below the rate which develops on the market." [Fuller June 2019, p. 2] Hulsmann argues, "On some monetary issues, virtually all presentday Austrian economists agree. Central banks and their specific product, fiat paper money, are inflationary institutions that disrupt the economy and serve no other purpose but redistributing income within society. Fiat paper money is an inherently statist institution because it has to be constantly protected through legal-tender laws and other forms of government intervention. It can be produced in virtually unlimited quantities by the printing press. This monetary inflation creates moral hazard for the prospective beneficiaries, and wrecks the economy through booms and busts. Central banks should therefore be abolished as quickly as possible. Superior alternatives are readily available ... The main element of a libertarian monetary reform is therefore to immediately abolish all forms of currency control (such as legal-tender laws, taxes on metals, and so forth). Moreover, all governments should give back the gold and silver that they stole from their citizens when they established their national fiat monies." [Hulsmann 2000, p. 101, Italics added]

\section{It is not the fact that private banks will manage fiat money better than the government or the central bank can manage}

The essence of the Austrian economists' objection to the central bank's (or the government's) interference with money and banking is that the arbitrary creation of unlimited fiat money and arbitrary reduction of interest rates by the central bank are the primary causes of boom-bust cycle. They argue that moneyissuing private banks cannot create unlimited fiat money due to the fear of being insolvent and will not reduce interest rate to such a low amount that may lure people to borrow more money and to invest in unproductive or unsustainable projects. 
However, they are wrong in assuming that private banks will act wisely. In the past, when there was no central bank, there were many money-issuing private banks and bank-failure became an epidemic. Therefore, it is better to keep money-issuing authority with the central bank so that the customers may not face loss of their entire savings in the event of failure of any private bank.

\section{Conclusion}

In the free private banking system (as is prescribed by the Austrian School), freedom (from government control) of money-creation will not be enjoyed by each and every people. People will be preys of the money- making and financial institutions whose sole purpose are to make profit for their own (and not for public spending as the government does with money). They will be puzzled to choose money which is more stable or sound. Besides, there will be competitions among different banks on interest rates for attracting prospective borrower, and thus interest rates will be the minimum. There will be no central authority to correct the inflation or deflation rate through setting of bank-rate, repo-rate etc. There will be complete chaos in the monetary and financial activity of the economy. Inflation (expansion of money) will be unbridled. Bankers will begin to keep reserve other than gold and silver if they become scarce. Besides, there is no guarantee that the bankers will not recourse to creating fiat or fiduciary money. Thus, the hope that the Austrians are making that inflation of money would be restricted by the limited availability of gold and silver and by the cost of mining and minting gold and silver into money, will be evaporated. Thus, the very problems of government-money like inflation (expansion of money) and low interest rate will be greater in the private banking system. Over and above, all profits from monetizing and banking will drain wealth from the borrowers to the money-makers and bankers and will not be used for public purpose. Again, a huge labor-force will be engaged in money making; otherwise, their labor could be used for production of consumer goods. A huge volume of different kinds of metals will be mined and minted not for consumption but only to make mediums of exchange. If it were fiat money then all such labor and metal would not be wasted.

Hayek himself accepts that "People will not be protected from the harmful effects of concurrent currencies. "It remains true, however, that so long as good and bad currencies circulate side by side, the individual cannot wholly protect himself from the harmful effects of the bad currencies by using only the good ones in his own transactions. Since the relative prices of the different commodities must be the same in terms of the different concurrent currencies, the user of a stable currency cannot escape the effects of the distortion of the price structure by the inflation (or deflation) of a widely used competing currency. [Hayek (1976) 1990 p.89]

The free private banking system, prescribed by the Austrian School, will lead to decease in production, employment and distribution system because they recommend that to keep the purchasing price of the money the private banks should restrict or reduce their issues. On the other hand, by depriving the government of selling bonds (which according to this school leads to fiduciary money) they want to reduce government expenditure for public utility services. Hazlitt writes, "To avoid irreparable damage, the budget must be balanced at the earliest possible moment, and not in some sweet by-and-by. Balance must be brought about by slashing reckless spending, and not by increasing a tax burden that is already undermining incentives and productions." [Hazlitt Sept 1978] If aggregate money supply is not increased or stopped or reduced then the whole economy will suffer from liquidity crunch and economic activities will be slowed down. And, if governments are not allowed to make deficit budget or to increase tax, then the government will not be able to serve the public purpose properly.

Both private banks and the public will be confused to assess the value of which money (among various moneys, various denominations and various metal-moneys) will remain constant or stable. They will have to check and compare every second value of which money is rising or falling. Hayek wrote, "Electronic calculators, which in seconds would give the equivalent of any price in any currency at the current rate 
would soon be used everywhere." [Hayek (1976) 2009, p. 19] All of them will feel insecure and uncertainty.

Every people will be bound to keep several types of money to be able to buy commodities because it may so happen that when they will buy some commodity the seller may decline to accept any or all kind of money. Besides, there is every possibility that some of the money-issuer banks and some of the moneyholding public will lose the value of their currencies.

Austrian economists could not definitely suggest that central bank must be dissolved. Sometimes they say that they only want to abolish the monopoly of the central bank to issue money, meaning that private banks may be allowed to issue money side by side of the central bank. Sometimes, they say that central bank should be abolished altogether, meaning only private banks will issue money and that there will be no central bank to issue money or control any monetary policy. This is a serious contradiction in the suggestion of Austrian economists. However, Hayek accepts that government may choose one kind of money as legal tender to be able to receive payments of taxes and other dues to it by the people. He wrote, "Is it not essential that the law designate one kind of money as the legal tender? This is, however, true only to the extent that, if the government does issue money, it must also say what must be accepted in discharge of debts incurred in that money. And it must also determine in what manner certain noncontractual legal obligations, such as taxes or liabilities for damage or torts, are to be discharged." [Hayek (1976) 2009, p. 17] Hayek writes, "A government must of course be, free to determine in what currency taxes are to be paid and to make contracts in any currency it chooses (in this way it can support a currency it issues or wants to favour)." [Hayek (1976) 1990, p. 40]

Now, if government chooses the currency of its own or of any other private banks as the legal tender, then, there is every possibility that the currencies that are not chosen as legal tender may be less acceptable to the people. People will be bound to use the legal tender money even if its value is reduced in the market in competition to other currencies. Then, nobody can refuse to accept that legal tender currency in exchange of any commodity. And, the purpose of exchange will be fulfilled only by using that legal tender currency. Then, private bankers will not be able to make much inroad in the market by issuing their currencies; even if those currencies are backed by only commodities (and are not fiduciary or fiat money).

Hayek argues that in the private banking system recession will be localized and not far reaching as to affect global economic and financial system. He writes, "even the complete collapse of one currency would not have the disastrous far-reaching consequences which a similar event has today. Though the holders of cash, either in the form of notes or of demand deposits in a particular currency, might lose their whole value, this would be a relatively minor disturbance compared with the general shrinkage or wiping out of all claims to third persons expressed in that currency." [Hayek (1976) 1990, pp. 128-129]

However, Hayek suggested that private banks should have the freedom to open their branches in every country throughout the globe. If such a big bank whose branches are spread throughout the globe fails or becomes bankrupt then the repercussions will more devastating while if a central bank collapses the effect will be confined only to the boundaries of the nation.

Hayek argued for commodity money and prescribes the abolition of government's power to create money mainly because, as he explained, government cannot restrain itself from issuing fiat money. However, he himself is ready to allow the private money-issuers to issue fiat money. Then, he should not blame government of inflating money supply and prescribe abolition of government's power of issuing fiat 
money. His suggestion for competing private fiat currencies will definitely create chaos and cause harm to the economy and ruin the economy permanently.

\section{Suggestion: the basic defect in the economy and its remedy}

The problem is not who issues the money, whether it is a private banker, the central bank or the government. The problem is also not whether money is a commodity or debt-money (fiat money). The problem is that money enters the economy as debt from its issuer. And it is the real problem.

Let me explain my point briefly. Only the central bank creates money. Money can enter into the economy only when the CB injects money as a loan. This system of injecting money as loans irrecoverably affects the economy.

Think of a zero-hour when no money is there in a nation. As only the Central Bank (CB) has the sole authority to create and inject money in the economy of a nation, so the money will be available only when the CB will lend money. The CB gives loans only to the Public Sector Banks (PSBs) or Commercial Banks.

Consider that the total amount of money the CB injects as a loan to the PSBs is $\$ 100$ million. The PSBs give the whole amount of $\$ 100$ million only to the commodity-producing companies. The producing companies spend the whole amount of $\$ 100$ million only for producing commodities (without spending on infrastructures, construction, etc). Then the cost price of the total products is $\$ 100$ million.

Consider that the CB charges 10\% interest on the loan from the PSBs. The PSBs will add say 5\% interest for handling and other charges. Consider that producing companies will not make any profit. Even then the total charges will amount to $(10+5) \%$ of $\$ 100$ million i.e. $\$ 15$ million. Thus, the minimum aggregate sale price of all the products/ commodities will be $\$ 100$ million $+\$ 15$ million $=\$ 115$ million .

The money spent by the producing companies has gone to the hands of the people. Therefore, the total amount of money in the hands of the people will be $\$ 100$ million. If, for argument's sake, we consider that the people spend all the money for buying those commodities which are produced by these producing companies only, then commodities worth $\$ 100$ million will be sold and commodities worth $\$ 15$ million will remain unsold.

However, people who got this $\$ 100$ million will not spend money to buy only those commodities that are produced by those companies. They will buy goods and services like vegetables, meat, household labor, fruit, fish for the production of which such financing is not necessary Thus, a portion of the money will be spent to buy other commodities that have not been produced using the money that the $\mathrm{CB}$ has lent. A portion will be paid as tax to the government. A portion of the money will be saved in the banks or government bonds. A portion will remain in the wallets of the people. In that case, the number of unsold commodities of the producing companies who took loans from the PSBs will worth more than \$15 million.

Thus, the Central Bank's practice/mode of injecting money into the economy as loan through the PSBs will create the following problems. (1) The interest that is to be paid will increase the cost price /saleprice. It will increase Consumer Price Index. (2) Commodities will remain unsold and it causes the recession. (3) As products remain unsold (in this case at least $15 \%$ or more) production units suffer losses. 
(4) The production unit may reduce their production or may declare closure. (5) It may decide to layoff to reduce its loss. (6) The production units will fail to repay their loan (in this case 15\%) to the PSBs. (6) It will cause NPA (Non-Performing Assets) of the PSBs to increase. (6) The PSBs will declare themselves insolvent or bankrupt. (7) Employment will be reduced, as the corporate sector will reduce the number of their employees. And, so on. (8) After repayment of the principal amount of $\$ 100$ million (if it can be done at all) to the $\mathrm{CB}$, there will be no money left in the economy. No economic activity will be possible. Acute recession or the collapse of the economy will take place. Therefore, to keep the economy running the $\mathrm{CB}$ will have to inject more money into the economy as loan. This will burden the economy more and more with un-repaid loans. Loans will be increased with the progress of time. However, the CB can inject money into the economy only if anybody approaches the $\mathrm{CB}$ for borrowing. The $\mathrm{CB}$ will not extend the loan again to a defaulting borrower. It will extend loan to a borrower that has creditworthiness. However, the aggregate loan of the non-government sectors will keep on increasing. "Therefore, the basic systemic defects with the origin of money and with the process of injecting money into the economy should be corrected. Only then, the economy will be free from various maladies [like the occasional boom-bust cycle and recession or depressions]." [Adak, Oct. 2016, p. 2]

Therefore, economists should think of abandoning the present practice of lending money to the economy as debt. An alternative rational theory should be framed so that money may not originate as debt-money. Money must originate as debt-free. However, I am avoiding here to suggest how money can originate debt-free because this is outside the scope of this paper. I wish to write a separate paper on this issue. Economists and policymakers should find or formulate a new theory by which it will be possible to make money debt-free so that the economy may never be overburdened with increasing debt-burden.

\section{Limitations of my paper}

I have tried to assess almost all the assertions or theories that are specialties of the Austrian School brand. However, I may miss or overlook certain points that need to be assessed.

However, it is necessary to define money and to trace its origin, but I have not tried to do that exercise, because the aim of this paper is only to make an assessment of the Austrian School's understanding of economics and their alternative suggestions. In this paper, I have avoided suggesting what should be the rational definition of money and how money can be created so that the government does not have to take any loan and sufficient money may be available for achieving full employment or to achieve a sustainable economic growth without being hampered by an occasional downturn or recession. I wish to write a separate paper on this issue. 


\section{References:}

Adak, Naba Kumar. Oct. 2016. Proper Definition of Money is Necessary to Eliminate Business Cycle and Achieve Sustainable Economic Growth, Proceedings of 6th Global Business and Finance Research Conference 27 - 29 October 2016, Taipei, http://www.worldbizins.org/img/1499922068.pdf

Blanchette, Jude. Nov 2004. Henry Hazlitt on Gold, The Freeman

Bradley, Dr. Anne. Sept 2013. Should We Create Jobs or Create Wealth?

Buzzeo, Fred. 27 Dec 2010. Job Creation and Other Economic Myths, Mises Daily Articles

Ebeling, Richard M. 02 Aug 2012. -Sound Money, Monetary Freedom, and the Government

Fuller, Edward W. June 2019. Mises on 100 Percent Reserve Banking, Mises Wire

Hayek, Friedrich A. June- Sept, 1943. "A Commodity Reserve Currency”, The Economic Journal, Vol. 53, No. 210/211, pp. 176-184.

Hayek, Friedrich. 1987 (1979). "Toward a free-market monetary system," in James A. Dorn and Anna J. Schwartz (eds.), The Search for Stable Money, Chicago: University of Chicago Press

Hayek, Friedrich, A. (1976)1990. Denationalization of Money - The Argument Refined, third ed., London: The Institute for Economic Affairs

Hayek, Friedrich, A. (1976) 2009. Choice of Currency: A Way to Stop Inflation, The Institute of Economics Affairs

Hayek, Friedrich, A. 10 Oct 2014. Hayek’s Free Market Money

Hayek, Friedrich, A. April 2019. A Free Market Monetary System, Mises Institute

Hazlitt, Henry. 1946. Economics in One Lesson, Ludwig von Mises Institute

Hazlitt, Henry. 1969. Man vs. The Welfare State (New Rochelle, N.Y.: Arlington House

Hazlitt, Henry. 13 Sept 1978. Hazlitt Summarizes Views of Inflation For 'Misled' Readers, Wilton Bulletin

Herbener, Jeffrey M. 2002. Ludwig von Mises On the Gold Standard and Free Banking, The Austrian Economics, Quarterly Journal of Austrian Economics, Vol. 5, No. 1, (Spring 2002), 67-91

Horwitz, Steven. April 2012. Creating Job versus Creating Value, FEE

Huerta de Soto, Jesus. 2009. Money, Bank Credit and Economic Cycles, second ed., Auburn: The Ludwig von Mises Institute,

Hulsmann, Gorg Guido. 1996. Free Bank and the Free Bankers, The Review of Austrian Economics, Vol. 9, No. 1 
Hulsmann, Gorg Guido. 2000. Banks Cannot Create Money, The Independent Review, Vol. V, No. 1, Summer 2000, ISSN 1086-1653, pp. 101-110

Hülsmann, Jörg, G. Summer 2004. Legal Tender Laws and Fractional-Reserve Banking, Journal of Libertarian Studies, Volume 18, no. 3, pp. 33-55

Hulsmann, Jorg Guido. 2008. The Ethics of Money Production, Ludwig von Mises Institute

Hulsmann, Jorg Guido. Feb. 2015. Why the Austrian Understanding of Money and Banks Is So Important, Mises Daily

Jonny, 08 Oct 2012. Full Employment is not the Goal

Lee, Dwight R. Jan 2000. Creating Job vs. Creating Wealth, FEE

Menger, Carl. (1892) 2009. On The Origins of Money, Auburn: The Ludwig von Mises Institute

Menger, Carl. (1976) 2007. Principles of Economics, Ludwig von Mises Institute

Mises, Ludwig von. (1912) 1980.The Theory of Money and Credit. H.E. Batson, trans. Indianapolis, Ind.: Liberty Fund.

Mises, Ludwig von. 1953. The Theory of Money and Credit, new ed., New Haven: Yale University Press

Mises, Ludwig von. (1949) 1998. Human Action: A Treatise on Economics. Scholar's Edition. Auburn, Ala.: Mises Institute

Mises, Ludwig von. (1949)1966. Human Action, $3^{\text {rd }}$ rev. ed. Chicago: Contemporary Books

Mises, Ludwig von. 1996. Human Action: A Treatise on Economics, Irvington-on-Hudson, N.Y.: Foundation for Economic Education

Mises, Ludwig von. 11 June 2010. The Monetary or Circulation-Credit Theory of the Trade Cycle, Mises Daily Articles

Mises, Ludwig von. 11 Sept 2018. Malinvestment, Not Overinvestment, Causes Boom, Mises Daily Articles

Murphy, Robert P. 14 June 2010. The Factional Reserve Banking Question, Mises Daily Articles

Murphy, Robert P. 18 June 2019. More than Quibbles: Problems with the Theory and History of Fractional Reserve Free Banking, QJAE

Ravier, Adrian. No date. Friedrich Hayek on Monetary and Banking Sytems Reform, SSRN

Rothbard, Murray N. 2004. Man, Economy, and State, with Power and Market -Ludwig von Mises Institute

Rothbard, Murray N. 2007. The Case Against the Fed -Ludwig von Mises Institute 
Rothbard, Murray N. Undated. Timberlake on the Austrian Theory of Money -A Comment, The Review of Austrian Economics

Rothbard, Murray N. Undated 1. Austrian Definitions of the Supply of Money, from New Directions in Austrian Economics, pp. 143-156

Salerno, Joseph T. Sept 1982. The Gold Standard - An Analysis of Some Recent Proposals, Cato Institute Policy Analysis No. 16

Sieron, Arkadiusz. No date. Why Hayek was Wrong on Concurrent Currencies

Selgin, George. 1999. "Ludwig von Mises and the Case for Gold." Cato Journal 19(2): 259-77

Selgin, George. 2000. Should we let Banks Create Money? The Independent Review, Vol. V, No. 1, Summer 2000, ISSN 1086-1653, PP. 93-100

Shostak, Frank. June 2017. Fractional-Reserve Banking and Money Creation

Shostak, Frank. 11 Aug 2017. Employment Is Not the Key to Economic Growth, Mises Wire

Shostak, Frank. 02 Jan. 2019. Boom-Bust Cycles and Easy Money, Mises Wire

Shostak, Frank. April 2019. Can Government Stimulus Bring Us Out of Recession? Mises Wire 